\title{
Ensuring the Safety of Classical Biological Control for Cabbage Seedpod Weevil in Canada: Assessment of the Ecological Host Range of Candidate Ectoparasitoids in Europe and Clarification of their Taxonomic Status
}

\author{
Dissertation \\ to obtain the Ph. D. degree \\ in the Faculty of Agricultural Sciences, \\ Georg-August-University Göttingen, Germany
}

presented by

Franck Muller

born in Clamart, France

Göttingen, July 2006 
D7

1. Referee: Prof. Dr. Stefan Vidal

2. Co-referee: Prof. Dr. Teja Tscharntke

3. Examiner: Prof. Dr. Matthias Schaefer

Date of dissertation: 13 Juli 2006 


\section{Summary}

Classical biological control of insect pests and weeds can lead to potential conflicts, particularly if the insect pest and weed agents are closely related. Such a conflict may occur in biological control of the Cabbage Seedpod Weevil (CSPW), Ceutorhynchus obstrictus (Marsham) [=C. assimilis (Paykull); see Colonnelli (2004)] (Coleoptera: Curculionidae), which belongs to the same subfamily, Ceutorhynchinae, as a number of agents introduced or proposed for introduction against invasive alien weed species in North America. The CSPW is a serious pest of canola and rapeseed in North America. Some of the known European parasitoids such as Trichomalus perfectus Walker and Mesopolobus morys Walker (both Hym.; Pteromalidae) show the greatest potential for incorporation into an IPM programme in North America and are currently being considered for introduction. Prior to importation, several issues have to be assessed, and results are presented here:

Taxonomy of the European species of the genus Trichomalus and Mesopolobus associated to Ceutorhynchinae hosts were revised and illustrated keys provided to ensure up to date information is available to biological control practitioners. A three years field survey has been carried out in five European countries to field collect Ceutorhynchinae hosts, rear their ectoparasitoids and identify them. Furthermore, implications of the host-parasitoid associations recovered by the surveys are discussed relative to introduction of species to North America for classical biological control of cabbage seedpod weevil.

The host specificity of the candidate ectoparasitoids has to be determined in their native cultivated and non-cultivated habitats. A three year field survey has been carried out to document the European parasitoid assemblages associated with several Ceutorhynchinae species either already introduced in North America as classical weed biological control agents (Microplontus edentulus (Schultze) against scentless chamomile, Tripleurospermum perforatum (Mérat) Laínz (=Matricaria perforata Mérat) [Asteraceae]; Hadroplontus litura (Fabricuius) against Canada thistle, Cirsium 
arvense (L.) Scopoli [Asteraceae]), proposed for introduction (Ceutorhynchus turbatus Schultze against hoary cress, Lepidium draba L. (=Cardaria draba) [Asteraceae]) or of importance in term of conservation (Ceutorhynchus typhae $(=C$. floralis) (Paykull) on Shepherd's purse, Capsella bursa-pastoris (L.) Medicus [Brassicaceae]). These results are discussed to estimate potential non-target effects on other Ceutorhynchinae species and implications for classical biological control of cabbage seedpod weevil. 


\section{Table of Contents}

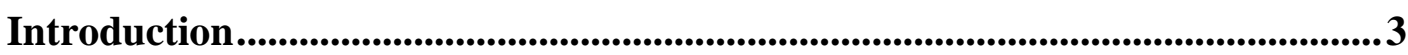

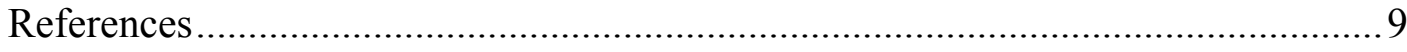

A Review of the Species of Trichomalus (Chalcidoidea: Pteromalidae) Associated with Ceutorhynchus (Coleoptera: Curculionidae) Host-Species of European Origin ............................................................................................................14

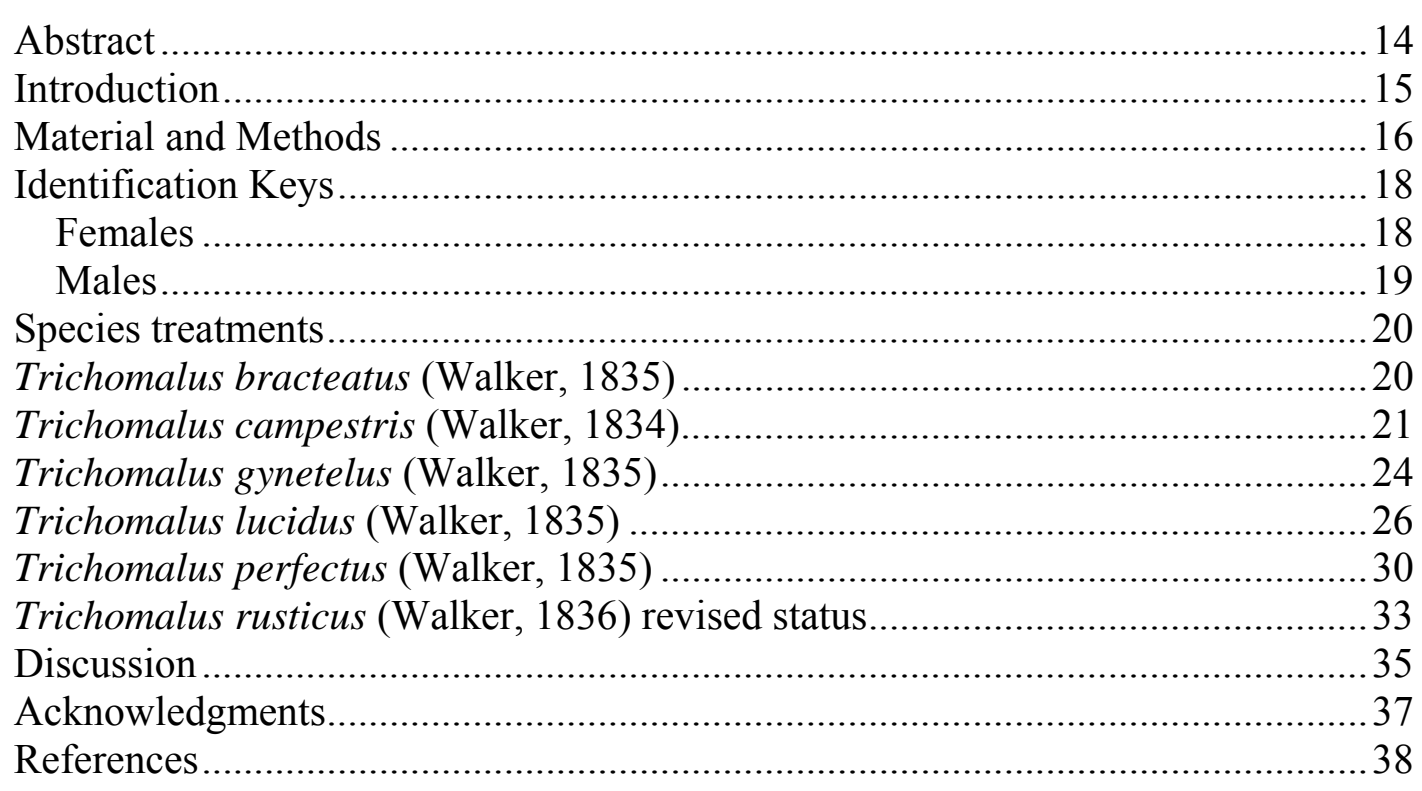

A Review of the Species of Mesopolobus (Chalcidoidea: Pteromalidae) Associated with Ceutorhynchus (Coleoptera: Curculionidae) Host-Species of European Origin. .............................................................................................................41

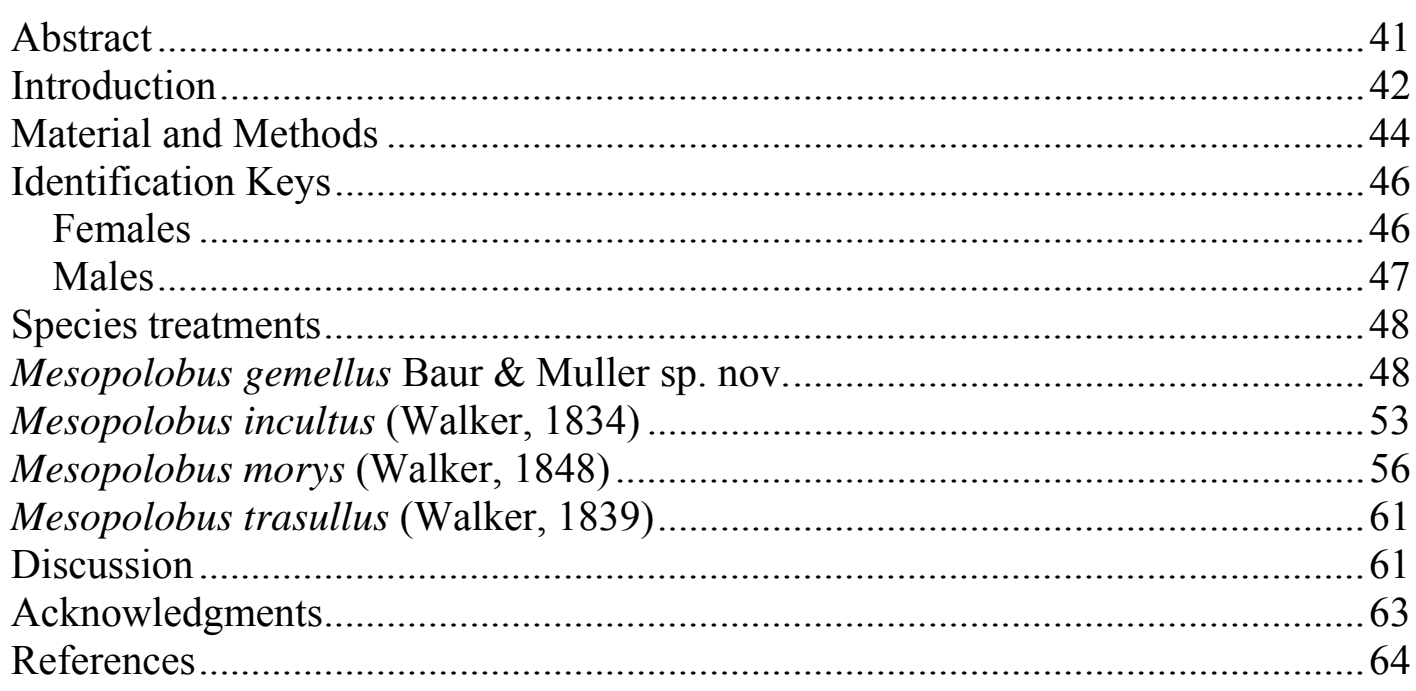

European Ectoparasitoid Assemblages of Two Classical Weed Biological Control Agents Released in North America: Ensuring the Safety of Biological Control Agents for Cabbage Seedpod Weevil .

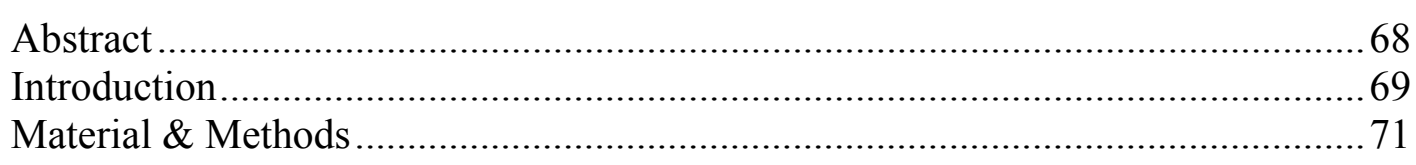




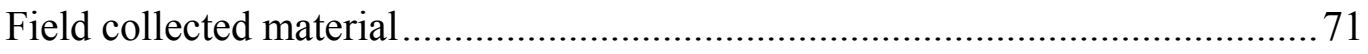

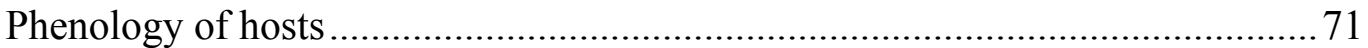

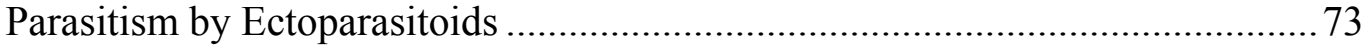

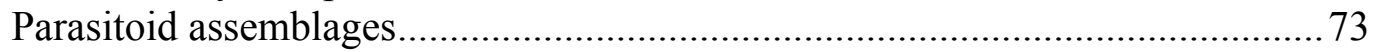

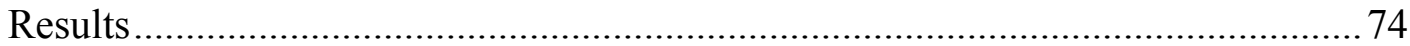

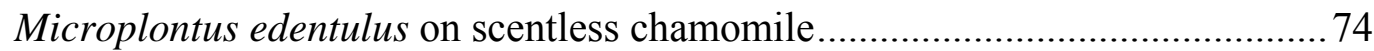

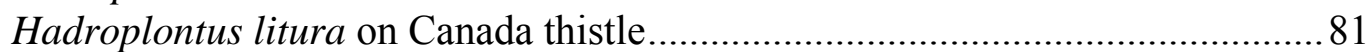

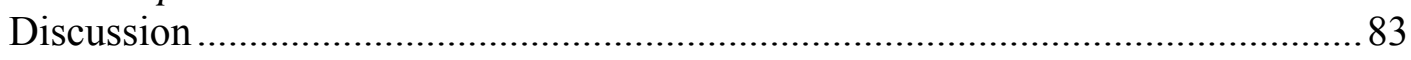

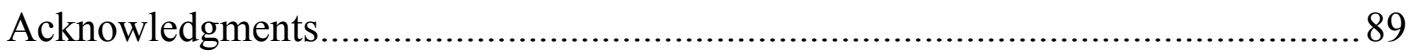

References......................................................................................... 90

European Ectoparasitoids of Two Ceutorhynchinae Associated with Shepherd's Purse and Hoary Cress: Assessing Safety Requirements for Classical Biological Control of Cabbage Seedpod Weevil.........................................96

\begin{tabular}{|c|}
\hline Abstract. \\
\hline Introduction... \\
\hline 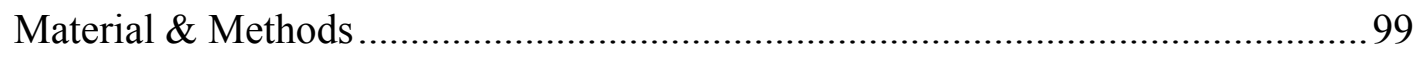 \\
\hline 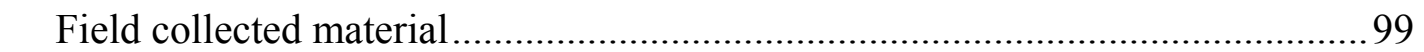 \\
\hline Phenology of Ceutorhynchinae hosts... \\
\hline Parasitism by ectoparasitoids.............. \\
\hline Parasitoid assemblages.. \\
\hline Results.............................. \\
\hline 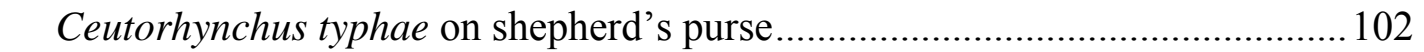 \\
\hline Ceutorhynchus turbatus on hoary cress..... \\
\hline 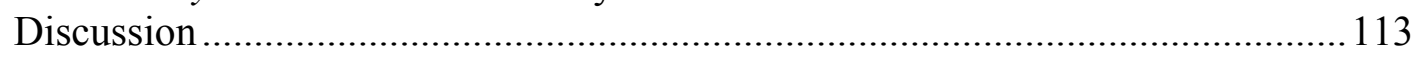 \\
\hline Acknowledgments... \\
\hline (1) \\
\hline Discussion \\
\hline 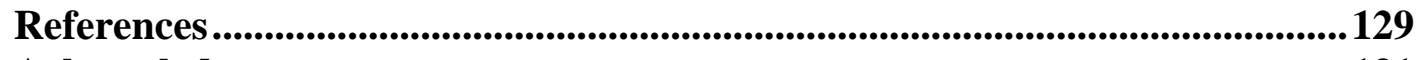 \\
\hline Acknowledgments ................................... \\
\hline
\end{tabular}




\section{Introduction}

The Convention on Biological Diversity defines an invasive alien species as follows "an alien species whose introduction and spread threatens ecosystems, habitats or species with socio-cultural, economic and/or environmental harm, and/or harm to human health" (COP, 2002). Biological invasions by non-native species constitute one of the leading threats to natural ecosystems and biodiversity, and impose an enormous cost on agriculture, forestry, fisheries, and other human enterprises, as well as on human health (Wittenberg \& Cock, 2001). The ways in which non-native species affect native species and ecosystems are numerous and usually irreversible (Wittenberg \& Cock, 2001). Furthermore, the costs of invasions are rising rapidly due partly to increasing human population density, and partly to intensification of production in genetically impoverished agricultural systems (Perrings et al., 2002). The negative effects caused by introduced exotic species on the environment are sometimes massive but often subtle (Wittenberg \& Cock, 2001).

The most important pathway of harmful exotics is unintentional importation through international trade (Perrings, 1996). One example illustrating the problem is the cabbage seedpod weevil (CSPW), Ceutorhynchus obstrictus (Marsham) $[=C$. assimilis (Paykull); see Colonnelli (2004)] (Fig. 1), which is a serious pest of oilseed rape and canola (Brassica napus L. and Brassica rapa L.) in North America where it was accidentally introduced, presumably with importation of seed stocks, about 75 years ago (McLeod, 1953). The pest was first recovered near Vancouver in British Columbia in 1931 (McLeod, 1953). It became widespread in British Columbia and the Pacific Northwest of North America and is believed to have dispersed throughout most of the United States (Baker, 1936; Hagen, 1946; Crowell, 1952; Walz, 1957; Boyd \& Lentz, 1994; Buntin et al., 1995). More recently, C. obstrictus was found in southern Alberta in 1995 (Carcamo et al., 2001) and has since spread to central Alberta and western Saskatchewan (Dosdall et al., 2002). In eastern Canada, C. obstrictus was found in Quebec in 2000 (Brodeur et al., 2001) and in Ontario in 2001 (Mason et al., 2003a). Based on surveys conducted from 1997 to 2000, Dosdall et al. (2002) determined that it is dispersing at approximately $55 \mathrm{Km}$ per year. 
Consequently, they predicted that C. obstrictus will eventually establish throughout the entire canola-growing region of western Canada. Furthermore, Olfert and Weiss (Olfert \& Weiss, 2006) predicted that with increases in temperature due to climate change the risks associated with C. obstrictus will become more severe in areas it presently occupies, and be able to establish in new localities.

Its discovery immediately raised concern within Canada's canola industry because $C$. obstrictus is usually considered the most economically important pest infesting oilseed rape during pod development (Walters \& Lane, 1994). The potential for yield loss in northern Idaho, USA, was estimated at $15-35 \%$ in untreated winter rape and

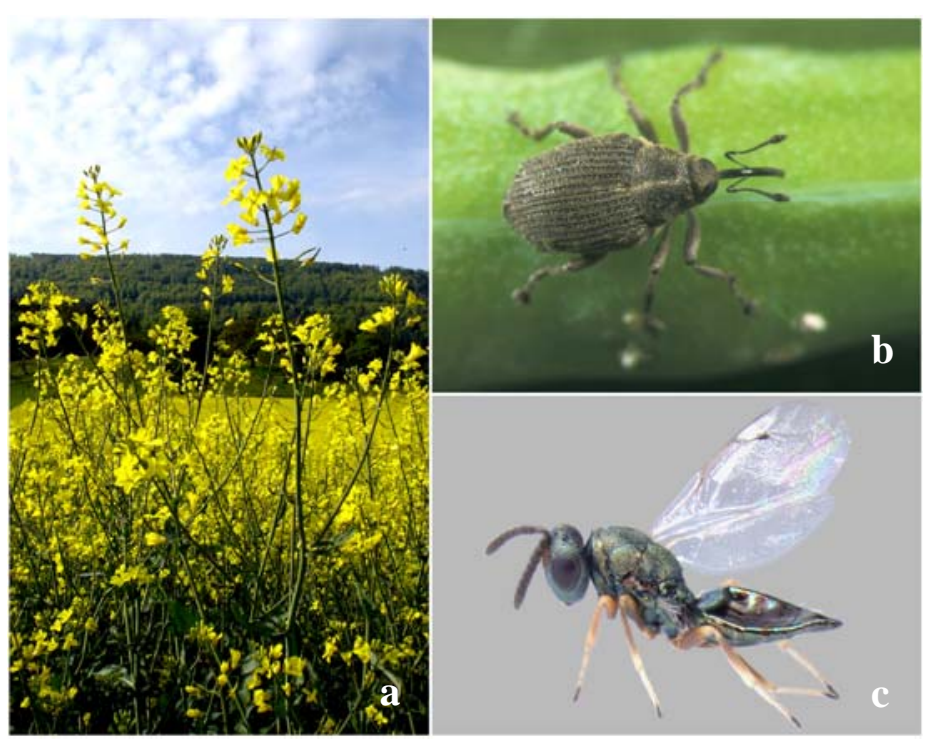

Fig. 1. Three trophic levels a) the crop : Brassica napus L., b) the pest, Ceutorhynchus obstrictus Marsham, and c) its principal parasitoid species in Europe, Trichomalus perfectus Walker. 3-6 adults per sweep can cause economic losses (McCaffrey et al., 1986). Populations of C. obstrictus remained relatively low in southern Alberta from 1995 to 1998, but in 1999 and 2000 outbreak densities occurred over an area of about 100,000 ha of canola (Dosdall et al., 2002).

The biology of $C$. obstrictus has been studied in detail in Europe (Bonnemaison, 1957; Dmoch, 1965; Ni et al., 1990; Kjaer-Pedersen, 1992). The species is univoltine. Adults overwinter in soil or leaf litter outside agricultural fields and wild crucifers serve as important food for them in spring. Oilseed rape and other brassicaceous seed crops are colonized with the onset of flowering. The life cycle is better synchronised with winter than spring crops. Adults feed for $3-4$ weeks on buds, flowers, pods and stem tips before mating (Williams \& Free, 1979). This causes a delay in oviposition on winter rape, but oviposition starts immediately on spring rape. Females bore a hole through the pod wall with their rostrum and then insert a 
single egg into the pod, which is subsequently marked with an oviposition deterrent pheromone emitted from the abdomen (Kozlowski et al., 1983; Mudd et al., 1997). Females lay a total of 25-240 eggs, larvae hatch after 6-10 days and feed within the pods for 14-21 days (Bonnemaison, 1957). Each larva consumes about five seeds and mature larvae leave through an exit hole, drop to the soil, and pupate within a cocoon, usually before the crop is harvested (Fox \& Dosdall, 2003; Dosdall \& Moisey, 2004). Adults of the next generation emerge after 15-19 days and feed on any remaining crop pods or wild hosts during July and August before dispersing to overwintering sites (Bonnemaison, 1957). In spring, overwintered adults feed and females oviposit until June when they begin to die.

Ceutorhynchus obstrictus is currently controlled through the use of broadspectrum chemical insecticides in North America (Dosdall et al., 2001; Carcamo et al., 2005). In Europe, studies have shown that chemical insecticides have a negative impact on parasitoids associated with the pest in canola fields (Alford, 1995).

Compared to other control methods, classical biological control is considered as the most appropriate option to manage invasive alien species; if successful, it is often highly cost-effective, permanent, and self-sustaining (Wittenberg \& Cock, 2001). Classical biological control provides an opportunity to partially reconstruct the natural enemy complex of an invading alien pest (Mills, 1994), and can be integrated with other control methods in a sustainable integrated pest management approach. In Europe, populations of the seed-feeder C. obstrictus are suppressed by a wide range of natural enemies, some of which might have the potential to be considered as biological control agents for $C$. obstrictus in North America. Among them, the pteromalid wasps Trichomalus perfectus (Walker) and Mesopolobus morys (Walker) are the most abundant and together account for up to $80-90 \%$ parasitism of $C$. obstrictus in Europe, even at low pest densities (Buntin, 1998; Murchie \& Williams, 1998; Williams, 2003). Given the importance of parasitism in Europe (Harmon \& McCaffrey, 1996; Williams, 2003) to control C. obstrictus, there is potential for classical biological control agents to reduce C. obstrictus populations in recently infested areas.

In a first attempt at biological control of cabbage seedpod weevil, three European pteromalid parasitoid species were released in British Columbia, Canada in 1949 (McLeod, 1953). In their review of the scientific literature relating to parasitoids 
of the cabbage seedpod weevil, Murchie and Williams (1998) stated that "the study of literature is hampered by synonymy and misidentification". In fact, recent work by Gibson et al (2005) illustrated these words by stating that the species introduced as Trichomalus fasciatus (Thomson), Xenocrepis pura Mayr, and Habrocytus sp. for classical biological control of C. obstrictus were misidentifications of T. perfectus, $M$. morys and Stenomalina gracilis Walker (Hym.: Pteromalidae) respectively. In addition, Gibson et al. (2005; in press) determined that species reared subsequently from Brassica spp. seedpods in British Columbia and reported in the literature under the first three names were misidentifications of Trichomalus lucidus (Walker), Mesopolobus moryoides Gibson and one or both of Pteromalus puparum (Linnaeus) and T. lucidus, respectively. Therefore, neither $T$. perfectus nor $M$. morys are established in North America, but S. gracilis is newly recorded from British Columbia (Gibson et al., in press).

In a renewed classical biological control initiative against $C$. obstrictus, both T. perfectus and $M$. morys are being considered for introduction to Canada (Kuhlmann et al., 2002). In this context of misidentifications, false synonymies and lack of taxonomic information, it became critical to revise the species of Mesopolobus and Trichomalus associated with Ceutorhynchinae hosts in Europe. The work presented in the first two chapters of this thesis aims at clarifying the taxonomic status of the species involved, and providing up-to-date identification keys.

Prior to any introduction, field surveys are needed in the area of origin of candidate biological control agents to assess their ecological host range. The assessment of the host specificity in their area of origin facilitates accurate prediction of potential non-target host impacts in the area of introduction as proposed by Kuhlmann et al. (Kuhlmann \& Mason, 2002; Kuhlmann et al., 2006b). Based on current knowledge, host associations of candidate biological control agents of $C$. obstrictus in its area of origin are probably restricted to the genus Ceutorhynchus but certainly to the subfamily Ceutorhynchinae (Graham, 1956a; Graham, 1969; Yu et al., 2005; Noyes, 2006). Prior the assessment of the ecological host range of $M$. morys and T. perfectus, a list of non-target host species was selected under the principle that parasitoids of $C$. obstrictus might parasitize other Ceutorhynchinae hosts in the same feeding niche (seeds), in other above-ground feeding niches (stem and leaf), as well as 
in a feeding niche below ground (roots) (Kuhlmann et al., 2006a). In addition, Kuhlmann et al. (2006a) proposed that a phenological and geographical overlap of $C$. obstrictus (target) with closely related Ceutorhynchinae species (non-target) would lead towards a higher risk that parasitoids of the target species could parasitize nontarget species. In this context it is essential to know that several species of Ceutorhynchinae have been introduced, or are being considered for introduction, as classical biological control agents of weed species in North America. Those Ceutorhynchinae released or considered for introduction to control weeds in cultivated crops will be at great risk of potential attack if agents released for biological control of $C$. obstrictus are not specific to that species. This is the case for (1) Hadroplontus litura (Fabricius) released for the control of Canada thistle, Cirsium arvense (L.) Scopoli [Asteraceae]; (2) Microplontus edentulus (Schultze) for the control of scentless chamomile, Tripleurospermum perforatum (Mérat) Laínz (=Matricaria perforata Mérat) [Asteraceae], and (3) Ceutorhynchus turbatus (Schultze), considered for introduction against hoary cress, Lepidium draba L. (=Cardaria draba) [Asteraceae]. In addition, a fourth species, Ceutorhynchus typhae (=C. floralis) (Herbst), which is of conservation interest as it is part of the natural enemy complex associated with a weed in cultivated habitats, shepherd's purse, Capsella bursa-pastoris (L.) Medicus [Brassicaceae] has also been considered in this study. Results presented in the second part of this thesis document the parasitoid assemblages associated with these four species, with the aim of verifying whether or not the candidate biological control agents occur in these parasitoid assemblages and if safety issues apply or not for the classical biological control of C. obstrictus in Canada.

a Chapter 1 provides a review of the species belonging to the genus Trichomalus associated with Ceutorhynchinae hosts in Europe. In order to provide taxonomic clarifications for this genus, an illustrated identification key has been developed including description and revision of the taxonomic status of each species involved.

- In Chapter 2 species belonging to the genus Mesopolobus associated with Ceutorhynchinae hosts in Europe are reviewed and a species new to science 
discovered during this study is described. In order to provide taxonomic clarifications for the genus Mesopolobus, an illustrated identification key has been developed together with descriptions of the species and including a revision of the taxonomic status of each species involved.

- Chapter 3 deals with the potential conflicts that could occur between classical biological control of $C$. obstrictus and classical biological control of weeds. The objectives of this study were to: 1) describe the phenologies of $H$. litura and $M$. edentulus to determine if there is phenological overlap with $C$. obstrictus; 2) assess the parasitism levels, particularly by ectoparasitoids; and 3) determine the parasitoid assemblages associated with $M$. edentulus and $H$. litura.

a Chapter 4 presents the case of two Ceutorhynchinae species closely related to C. obstrictus that are part of the herbivore complex associated with two weed species. The objectives of this study were to: 1) describe the phenology of $C$. typhae and C. turbatus to determine if there is a phenological overlap with that of C. obstrictus; 2) assess the parasitism levels of C. typhae and C. turbatus, particularly by ectoparasitoids; and 3) determine the parasitoid assemblage associated with these two Ceutorhynchinae species. 


\section{References}

Alford, D. V. (1995). Observations on the impact of standard insecticide treatments on Trichomalus perfectus, a parasitoid of the seed weevil on winter oilseed rape in the UK. In: V. H. Paul, P. Gladders and I. H. Williams (Eds.) Proceedings of the Working group "Integrated control in oilseed crops". Zurich-Reckenholz, Switzerland,23-27.

Baker, W. W. (1936). Notes on the European weevil, Ceutorhynchus assimilis Payk., recently found in the state of Washington. Canadian Entomologist 8, 191-193.

Bonnemaison, L. (1957). Le charancon des siliques (Ceutorhynchus assimilis Payk.) Biologie et Méthodes de lutte. Annales de l'institut national de la recherche agronomique - Serie C: Annales des Epiphytes 8 (IV), 387-542.

Boyd, M. L. \& G. L. Lentz (1994). Seasonal incidence of the cabbage seedpod weevil (Coleoptera: Curculionidae) on rapeseed in West Tennessee. Environmental Entomology 23 (4), 900-905.

Brodeur, J., L. Leclerc, M. Fournier \& M. Roy (2001). The cabbage seedpod weevil, Ceutorhynchus obstrictus (Coleoptera: Curculionidae): a new pest of canola in northeastern North America. The Canadian Entomologist 133 (5), 709-711.

Buntin, G. D. (1998). Cabbage seedpod weevil (Ceutorhynchus assimilis, Paykull) management by trap cropping and its effect on parasitism by Trichomalus perfectus (Walker) in oilseed rape. Crop Protection 17, 299-305.

Buntin, G. D., J. P. McCaffrey, P. L. Raymer \& J. Romero (1995). Quality and germination of rapeseed and canola seed damaged by adult cabbage seedpod weevil, Ceutorhynchus assimilis (Paykull) (Coleoptera: Curculionidae). Canadian Journal of Plant Science 75 (2), 539- 541.

Carcamo, H. A., L. M. Dosdall, M. Dolinski, O. Olfert \& J. R. Byers (2001). The cabbage seedpod weevil, Ceutorhynchus obstrictus (Coleoptera: Curculionidae) - a review. Journal of the Entomological Society of British Columbia 98, 201-210.

Carcamo, H. A., L. M. Dosdall, D. Johnson \& O. Olfert (2005). Evaluation of foliar and seed treatments for control of the cabbage seedpod weevil (Coleoptera: Curculionidae) in canola. The Canadian Entomologist 137, 476-487. 
Colonnelli, E. (2004). Catalogue of Ceutorhynchinae of the world, with key to genera. Argania edito, Balmes, Barcelona. 124 pp.

COP (2002). Review and consideration of options for the implementation of Article $8(\mathrm{~h})$ on alien species that threatens ecosystems, habitats or species. In: Proceedings of the Conference of the Parties to the Convention on Biological Diversity (COP). The Hague. UNEP/CBD/COP/6/18/Add.11/Rev.11.

Crowell, H. H. (1952). Cabbage seedpod weevil control with Parathion. Journal of Economic Entomology 45, 545-546.

Dmoch, J. (1965). The dynamics of a population of the cabbage seedpod weevil (Ceuthorrhynchus assimilis Payk.) and the development of winter rape. Ekologia Polska A (13), 249-287.

Dosdall, L. M., D. Moisey, H. A. Carcamo \& R. Dunn (2001). Cabbage seedpod weevil fact sheet. Alberta Agriculture, Food and Rural Development Agdex 622-21, 1-4.

Dosdall, L. M. \& D. W. A. Moisey (2004). Developmental biology of the cabbage seedpod weevil, Ceutorhynchus obstrictus (Coleoptera: Curculionidae), in spring canola, Brassica napus, in western Canada. Annals of the Entomological Society of America 97 (3), 458-465.

Dosdall, L. M., R. M. Weiss, O. Olfert \& H. A. Carcamo (2002). Temporal and geographical distribution patterns of the cabbage seedpod weevil (Coleoptera: Curculionidae) in canola. The Canadian Entomologist 134 (3), 403-418.

Fox, A. S. \& L. Dosdall (2003). Reproductive biology of Ceutorhynchus obstrictus (Coleoptera: Curculionidae) on wild and cultivated Brassicaceae in southern Alberta. Journal of Entomological Science 38, 533-544.

Gibson, G. A. P., H. Baur, B. Ulmer, L. Dosdall \& F. J. Muller (2005). On the misidentification of the chalcid (Hymenoptera: Chalcidoidea) parasitoids of the cabbage seedpod weevil (Coleoptera: Curculionidae) in North America. The Canadian Entomologist 137, 381-403.

Gibson, G. A. P., D. R. Gillespie \& L. M. Dosdall (in press). The species of Chalcidoidea (Hymenoptera) introduced to North America for biological control of the cabbage seedpod weevil, and the first recovery of Stenomalina gracilis (Chalcidoidea: Pteromalidae). The Canadian Entomologist.

Graham, M. W. R. (1956). A revision of the Walker types of Pteromalidae (Hym., Chalcidoidea). Part 2 (including descriptions of new genera and species). Entomologist’s Monthly Magazine 92, 246-263. 
Graham, M. W. R. (1969). The Pteromalidae of North-Western Europe (Hymenoptera: Chalcidoidea). Bulletin of the British Museum (Natural History) Entomology (Suppl.16), 908pp.

Hagen, K. S. (1946). The occurrence of Ceutorhynchus assimilis (Paykull) in California. Pan-Pacific Entomologist 22, 73.

Harmon, B. L. \& J. P. McCaffrey (1996). Parasitism of adult Ceutorhynchus assimilis (coleoptera ; curculionidae) by Microctonus melanopus (hymenoptera : Braconidae) in northern Idaho and eastern Washington. Journal of Agricultural Entomology 14 (1), 55-59.

Kjaer-Pedersen, C. (1992). Flight behaviour of the cabbage seedpod weevil. Entomologia Experimentalis et Applicata 62 (1), 61-66.

Kozlowski, M. W., S. Lux \& J. Dmoch (1983). Oviposition behaviour and pod marking in the cabbage seed weevil, Ceutorhynchus assimilis. Entomologia Experimentalis et Applicata 34, 277-282.

Kuhlmann, U., L. M. Dosdall \& P. G. Mason (2002). Ceutorhynchus obstrictus (Marsham), cabbage seedpod weevil (Coleoptera: Curculionidae). In: P. G. Mason and J. T. Huber (Eds.) Biological Control Programmes in Canada, 1981-2000. CABI Publishing, Wallingford, Oxon, U.K. 52-58.

Kuhlmann, U. \& P. G. Mason (2002). Use of field host range surveys for selecting candidate non-target species for physiological host specificity testing of entomophagous biological control agents. In: R. G. Van Driesche (Ed.) Proceedings of the 1st International Symposium on Biological Control of Arthropods. United States Department of Agriculture, Forest Service, Washington, USA Hawaii. 370-377.

Kuhlmann, U., P. G. Mason, H. L. Hinz, B. Blossey, R. A. De Clerck-Floate, L. Dosdall, J. P. McCaffrey, M. Schwarzlaender, O. Olfert, J. Brodeur, A. S. McClay \& R. N. Wiedenmann (2006a). Avoiding conflicts between insect and weed biological control: selection of non-target species for test list to assess host specificity of cabbage seedpod weevil parasitoids. Journal of Applied Entomology 130 (3), 129-141.

Kuhlmann, U., U. Schaffner \& P. G. Mason (2006b). Selection of non-target species for host specificity testing. In: F. Bigler, D. Babendreier and U. Kuhlmann (Eds.) Environmental impact of invertebrates for biological control of Arthropods: Methods and risk assessment. CABI Publishing., Wallingford, Oxon, UK. 15-37.

Mason, P. G., T. Baute, O. Olfert \& M. Roy (2003). Cabbage Seedpod Weevil, Ceutorhynchus obstrictus (Marsham) (Coleoptera: Curculionidae) in Ontario and Quebec. Journal of the Entomological Society of Ontario 134, 107-113. 
McCaffrey, J. P., L. E. O'Keefe \& H. W. Homan (1986). Cabbage seedpod weevil control in winter rapeseed. University of Idaho, Agricultural Experiment Station Information Series 782, 18-29.

McLeod, J. H. (1953). Notes on the cabbage ceedpod weevil, Ceutorhynchus assimilis (Payk.) (Coleoptera : Curculionidae), and its parasites. Entomological Society of British Columbia, Proc. 49, 11-18.

Mills, N. J. (1994). Parasitoid guilds: a comparative analysis of the parasitoid communities of tortricids and weevils. In: B. A. Hawkins and W. Sheehan (Eds.) Parasitoid Community Ecology. Oxford Science Publications. 516pp.

Mudd, A., A. W. Ferguson, M. M. Blight, I. H. Williams, P. Scubla, M. Solinas \& S. J. Clark (1997). Extraction, isolation, and composition of oviposition-deterring secretion of cabbage seed weevil Ceutorhynchus assimilis. Journal of Chemical Ecology 23 (9), 2227-2240.

Murchie, A. K. \& I. H. Williams (1998). A bibliography of the parasitoids of the cabbage seed weevil (Ceutorhynchus assimilis Payk.). IOBC wprs Bulletin 21 (5), 163-169.

Ni, X. Z., J. P. McCaffrey, R. L. Stoltz \& B. L. Harmon (1990). Effects of postdiapause adult diet and temperature on oogenesis of the cabbage seedpod weevil (Coleoptera: Curculionidae). Journal of Economic Entomology 83 (6), 2246- 2251.

Noyes, J. S. (2006). Universal Chalcidoidea Database. www.nhm.ac.uk/entomology/chalcidoids/index.html. last accessed 20-April2006.

Olfert, O. \& R. M. Weiss (2006). Impact of climate change on potential distributions and relative abundances of Oulema melanopus, Meligethes viridescens and Ceutorhynchus obstrictus in Canada. Agriculture, Ecosystems and Environment 113, 295-301.

Perrings, C. (1996). Free trade and exotic species introductions. Conservation Biology 10, 300-302.

Perrings, C., M. Williamson, E. B. Barbier, D. Delfino, S. Dalmazzone, J. Shogren, P. Simmons \& A. Watkinson (2002). Biological invasion risks and the public good: an economic perspective. ConservationEcology 6 (1), art. No. 1.

Walters, K. F. A. \& A. Lane (1994). The development of an improved strategy for cabbage seed weevil on oilseed rape. In: S. R. Leather, A. D. Watt, N. J. Mills and K. F. A. Walters (Eds.) Individuals, populations and patterns in ecology. Intercept, Andover, UK,. 187-197. 
Walz, A. J. (1957). Observations on the biologies of some hymenopterous parasites of the cabbage seedpod weevil in northern Idaho. Annals of the Entomological Society of America 50, 219-220.

Williams, I. H. (2003). Parasitoids of Cabbage Seed Weevil. In: D. V. Alford (Ed.) Biocontrol of Oilseed Rape Pests. Blackwell Science, Oxford. 97-112.

Williams, I. H. \& J. B. Free (1979). Compensation of oil-seed rape (Brassica napus L.) plants after damage to their buds and pods. Journal of Agricultural Science 92, 53-59.

Wittenberg, R. \& M. J. W. Cock (Eds.) (2001). Invasive Alien Species: A Toolkit of Best Prevention and Management Practices. CABI Publishing, Wallingford, Oxon, UK. 228 pp.

Yu, D., K. Van Achterberg, K. Horstmann \& J. S. Noyes (2005). Taxapad. Vancouver, BC, Canada. 


\title{
A Review of the Species of Trichomalus (Chalcidoidea:
}

\section{Pteromalidae) Associated with Ceutorhynchus (Coleoptera: Curculionidae) Host-Species of European Origin}

Franck J. Muller ${ }^{1}$, Hannes Baur ${ }^{2}$, Gary A. P. Gibson ${ }^{3}$, Peter G. Mason ${ }^{3}$ \& Ulrich Kuhlmann ${ }^{1}$

1- CABI Switzerland Centre, Rue des Grillons 1, 2800 Delémont, Switzerland

2- Naturhistorisches Museum, Bernstrasse 15, CH-3005 Bern, Switzerland

3- AAFC, Biodiversity and IPM, Research Centre, 960 Carling Avenue, Ottawa, Canada

\begin{abstract}
Six species of Trichomalus Thomson, 1878, were reared as parasitoids of Ceutorhynchinae hosts in Europe during surveys in 2000-2004. Trichomalus rusticus (Walker, 1836) is treated as a valid species, resurrected from synonymy under T. lucidus (Walker, 1835), and T lyttus (Walker, 1848) is transferred from synonymy under T. lucidus and newly placed in synonymy with T. rusticus. An illustrated key is given to differentiate the six species (T. bracteatus (Walker, 1835), T. campestris (Walker, 1834), T. gynetelus (Walker, 1835), T. lucidus (Walker, 1835), T. perfectus (Walker, 1835) and T. rusticus) except for males of T. bracteatus and T. gynetelus. Trichomalus campestris is newly recorded as a parasitoid of Ceutorhynchus cardariae. Implications of the host-parasitoid associations recovered by the surveys are discussed relative to introduction of species to North America for classical biological control.
\end{abstract}




\section{Introduction}

Colonnelli (2004) stated that Ceutorhynchinae (Coleoptera: Curculionidae) contained 1,316 species, making it one of the most speciose subfamilies of Curculionidae, which itself is the most speciose family of Coleoptera. Some species of Ceutorhynchinae are used worldwide as natural enemies for classical biological control of weeds to reduce their impact in crop and non-crop habitats (Julien \& Griffiths, 1998), but several species are known to be herbivorous pests of high economic importance in agricultural crops (Dieckmann, 1972; Mason \& Huber, 2002). One such species, the cabbage seedpod weevil, Ceutorhynchus obstrictus (Marsham) [=C. assimilis (Paykull); see Colonnelli (2004)], is a pest of Brassica napus L. (oilseed rape) in Europe and was accidentally introduced to western North America in the early 1930's (McLeod, 1953). It is now widespread in North America (Kuhlmann et al., 2002), though only recently was found in the Canadian provinces of Alberta (Carcamo et al., 2001), Saskatchewan (Dosdall et al., 2002), Quebec (Brodeur et al., 2001) and Ontario (Mason et al., 2003b). In the major canola (oilseed rape) production areas in Alberta and Saskatchewan, crop losses due to $C$. obstrictus have been reduced through registration of broad-spectrum insecticides (Mason \& Huber, 2002).

As an invasive alien species for North America, C. obstrictus was considered for classical biological control after its establishment, and in 1949 three species of larval ectoparasitoids were introduced from Europe to British Columbia, Canada (McLeod, 1962). McLeod (1953) reported one of these species as Trichomalus perfectus (Walker) (Hymenoptera: Chalcidoidea: Pteromalidae). Trichomalus perfectus is the most important parasitoid responsible for reducing populations of the cabbage seedpod weevil in Europe (Williams, 2003) and is one of several species of the genus known to be important members of parasitoid complexes associated with some Ceutorhynchinae species (Murchie \& Williams, 1998). Although follow up studies to prove establishment were not carried out, T. perfectus was considered as established in North America until very recently. Gibson et al. (2005) verified from voucher material that $T$. perfectus was indeed introduced into BC in 1949, but showed that all subsequent reports of $T$. perfectus in North America were based on misidentifications of another European species, Trichomalus lucidus (Walker). 
Classical biological control of $C$. obstrictus is again being considered for North America to provide a reduced-risk strategy alternative to insecticide applications. Accurate identification of natural enemies is the cornerstone of biological control and is essential when exotic species are introduced, especially when morphological differentiation among species is slight, such as for the species of Trichomalus associated with Ceutorhynchinae hosts. It is crucial to clarify the taxonomic status of closely related Trichomalus species to: 1) accurately document ecological data on the species associated with Ceutorhynchinae hosts in Europe, the area of origin of C. obstrictus, and 2) address safety issues in classical biological control initiatives.

In this paper we provide: 1) illustrated keys to differentiate females and most males of Trichomalus species known from Ceutorhynchinae hosts in Europe; 2) a list of type material examined together with notes on the concordance with specific characters of voucher specimens; 3) a complete list of all voucher specimens examined; 4) a short diagnosis for females and males or, if required, a more comprehensive description of the species for which taxonomic status is being changed.

\section{Material and Methods}

Our study is based primarily on surveys in Switzerland, Germany, France, Austria, Hungary, Romania and Ukraine during 2000-2004, which were made to obtain specimens of relevant species of Trichomalus associated with Ceutorhynchus. When stated as "individually reared", the specimens were obtained by dissecting host plants for Ceutorhynchus hosts having a larval ectoparasitoid and then rearing these individually to the adult stage (for detailed rearing methods see Chapter 3). "Mass collected" specimens were obtained by collecting and placing host plants in emergence boxes. Adult parasitoids emerged into glass vials and were collected, killed, air-dried, pinned, labelled and curated for later identification. All voucher specimens stated as collected by F. Muller, B. Klander, M. Grossrieder and M. Cripps were obtained during the 2000-2004 field surveys and are deposited in the Natural History Museum in Bern, Switzerland (NMBE). Additional material, including type specimens of relevant species, was obtained either from the NMBE or from the British Museum of Natural History (BMNH) in London, United Kingdom. 
Descriptions are based on observations made using a Leica MZ16 binocular microscope coupled to a Leica CLS $150 \mathrm{x}$ incandescent light source and a light diffuser placed over the specimen to reduce the effects of glare. Several images of a specimen were taken through the binocular microscope at different focal planes using a JVC KY-F70BU triple CCD digital camera and processed using the Syncroscopy Auto-Montage ${ }^{\mathrm{TM}}$ software suite. This enabled production of a single, composite, focused image, which allowed us to overcome the problems historically associated with inadequate depth of field for 3-dimensional imaging of tiny specimens. Images obtained from the Syncroscopy Auto-montage ${ }^{\mathrm{TM}}$ software suite were retouched using Adobe Photoshop CS ${ }^{\mathrm{TM}}$ to enhance clarity of the illustrations.

Terms for morphological features and sculpture follow Gibson et al. (1997) and Goulet \& Huber (1993). Terms for colours of various body parts are taken from Graham (1969). Measurements for each species were taken from about 6-10 air dried specimens, depending on availability.

The synonymy of most Trichomalus species is not quoted here because it often is extensive and is readily accessible electronically in the Universal Chalcidoidea Database (Noyes, 2006); however, for those species where we introduce some nomenclatural change, the complete synonymy is given. 


\section{Identification Keys}

\section{Females}

1 Procoxa testaceous, much paler than dark green body (Fig. 1b). Fore wing often with a dark discal cloud (Fig. 2a), basal fold bare and costal cell setal line widely broken in the middle T. campestris (Walker)

- $\quad$ Procoxa dark green with metallic tinge, concolorous with body (Fig. 1a). Fore wing hyaline (Fig. 2c, e, g, i), basal fold and costal cell with complete setal line.....

2 Fore wing with marginal vein at most $1.5 \mathrm{x}$ as long as stigmal vein and stigma relatively large (Fig. 2e). Flagellum with first funicular segment distinctly broader than pedicel in lateral view (Fig. 3c) T. perfectus (Walker)

- $\quad$ Fore wing with marginal vein at least $1.6 \mathrm{x}$ as long as stigmal vein and stigma comparatively smaller (Fig. 2c, g, i). Flagellum with first funicular segment about as broad as pedicel in lateral view (Fig. 3a) ........................................................ 3

3 Metacoxa densely setose dorsobasally (Fig. 4e) T. rusticus (Walker) Metacoxa sparsely setose dorsobasally (Fig. 4a) Gaster at most $2.5 \mathrm{x}$ as long as broad (Fig. 5c). Median area of propodeum 1.25$1.4 \mathrm{x}$ as broad as long. T. lucidus (Walker) Gaster about 2.4-3.4 $\mathrm{x}$ as long as broad (Fig. 5g). Median area of propodeum about 1.6-1.95 $\mathrm{x}$ as broad as long Gaster about 1.6-1.75 $\mathrm{x}$ as long as mesosoma; last tergite 1.0-1.6 $\mathrm{x}$ as long as its basal breadth (Fig. 5g) T. bracteatus (Walker) Gaster about $1.7-2.0 \mathrm{x}$ as long as mesosoma; last tergite $1.7-2.15 \mathrm{x}$ as long as its basal breadth T. gynetelus (Walker) 


\section{Males}

[note: T. bracteatus \& T. gynetelus are keyed out according to features given by Graham (1969)]

Procoxa testaceous, much paler than dark green body (Fig. 1b). Antenna (Fig. 3e) with scape long and stout, only about $3 \mathrm{x}$ as long as broad and broadest in middle, but about 1.0-1.2 x as long as eye height; flagellum with funicular segments 4-6 or at least 5 and 6 pale, remaining segments dark. Fore wing with basal fold bare and costal cell setal line widely broken in the middle (Fig. 2b). Gaster with a pale transverse band basally (Fig. 5b)..... T. campestris (Walker) Procoxa dark green with metallic tinge, concolorous with body (Fig. 1a). Antenna (Fig. 3b, d) with scape short and relatively slender, about $4 \mathrm{x}$ as long as broad and slightly expanded apically, and at most $0.8 \mathrm{x}$ as long as eye height; flagellum dark (Figs. 3b, d). Fore wing with setal lines on basal fold and on lower side of costal cell complete (Fig. 2d, f, h). Gaster at most with a pale spot basally (Fig. 5d, f) ....2 Gena slightly compressed and with a sharp edge near base of mandible (Fig. 6b). Pronotal collar almost as broad as mesoscutum (Fig. 8b), its anterior margin less strongly curved viewed from behind (Fig. 8b). Marginal vein 1.1-1.4 x as long as stigmal vein, stigma relatively large (Fig. 2f) T. perfectus (Walker)

- Gena rounded without sharp edge near base of mandible (Fig. 6a). Pronotal collar distinctly narrower than mesoscutum (Fig. 8a), its anterior margin more strongly curved viewed from behind (Fig. 8a). Marginal vein 1.5-1.8 x as long as stigmal

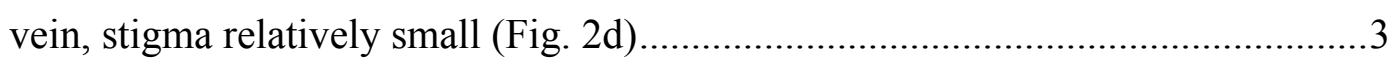
Metacoxa densely setose dorsobasally (Fig. 4e) T. rusticus (Walker) Metacoxa sparsely setose dorsobasally (Fig. 4b) 4

$4 \quad$ Propodeum medially about half as long as scutellum T. lucidus (Walker) Propodeum medially slightly less than half as long as scutellum 


\section{Species treatments}

\section{Trichomalus bracteatus (Walker, 1835)}

\section{Type material:}

Pteromalus bracteatus Walker, 1835, lectotype female (B.M. TYPE HYM. 5.3398) in BMNH, designated by Graham ) (examined by Baur).

\section{Material examined:}

ITALY, Como: Olgiate-Com. SW Pare, 721.0/74.0, 370m; coll. 15.VI.1992, leg. H. Baur (NMBE), collected by sweeping (1). SWITZERLAND, Bern: Boltigen, Vordere Reldigen, 592/164, 1420m.; coll. 12.VII.1997; leg. H. Baur (NMBE), collected by sweeping (1q); Bremgarten, Hoger, 599.4/202.9, 550m.; coll. 21.VI.2001; leg. H. Baur (NMBE); collected by sweeping (1\%); Rumendingen, 614.9/217.5, 510m.; coll. 26.V.1992; leg. H. Baur (NMBE); collected by sweeping (19). Jura: La Chaud-des-Breuleux, tourbière, 569/230, 970m.; coll. 18.VII.1996; leg. H. Baur (NMBE); collected by sweeping (1). Valais: NE Hohtenn (subalpline Weide), 625.65/130.75, 1460m.; coll. 30.vi.1992; leg. H. Baur (NMBE); collected by sweeping (1q). Oberwald, Gonerlital, 671/153, 1500m.; coll. 20.VI.1999; leg. H. Baur (NMBE); collected by sweeping (1 9 ). Vaud: Le Chenit, Burtignière (emergence trap), 502.3/156.8, 1050m.; coll. 7.-14.VIII.1994; leg. C. Vaucher (NMBE); collected by sweeping (19).

\section{Diagnosis:}

Female. Length 2.5-3.1 mm (Fig. 7g). Antenna in lateral view with first funicular segment at most slightly broader than pedicel. Procoxae dark green with metallic tinge, similar to body. Forewing hyaline (Fig. 2i); marginal vein $1.7-2.0 \mathrm{x}$ as long as stigmal vein; stigma small; basal fold and lower side of costal cell with complete setal lines. Metacoxa sparsely setose dorsobasally (Fig. 4d). Propodeum with median area 1.6-1.85 $\mathrm{x}$ as broad as long, from almost 


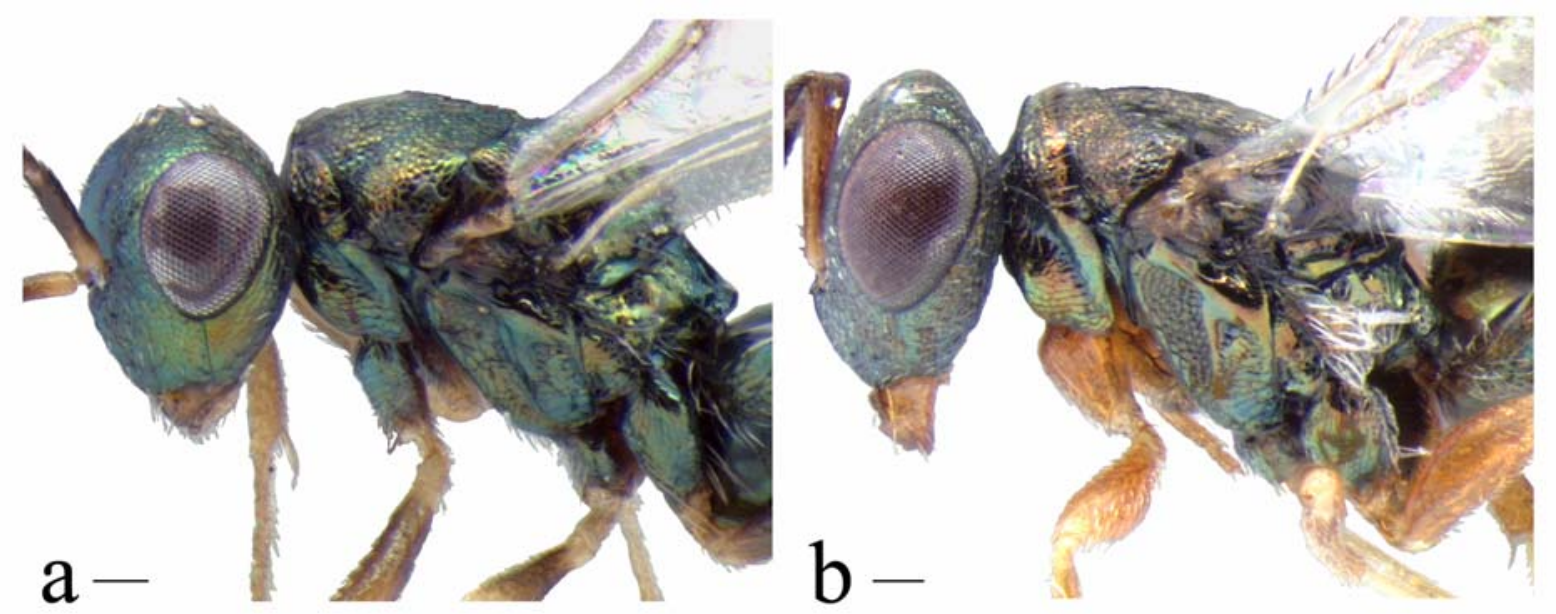

Fig. 1. Head and mesosoma (lateral) illustrating differences in procoxae coloration in $q$ of (a) Trichomalus bracteatus (Walker, 1835) and (b) Trichomalus campestris (Walker, 1834). Scale bars $=100 \mu \mathrm{m}$.

smooth to slightly strigose. Gaster $1.6-1.75 \mathrm{x}$ as long as mesosoma and $2.4-3.0 \mathrm{x}$ as long as broad; length of last tergite about 1.0-1.6 x its basal breadth.

Male. See characters given in the key.

\section{Remarks:}

We reared only females of T. bracteatus and T. gynetelus in our surveys. Females of theses two species are differentiated only by relatively subtle differences in gastral shape as given in the key. The differences mentioned by Graham (Graham, 1969) concerning the size of the fore wing stigma were actually not diagnostic for our specimens.

\section{Trichomalus campestris (Walker, 1834)}

\section{Type material:}

Amblymerus campestris Walker, 1834, lectotype female in BMNH, designated by Graham (Graham, 1956a) (not examined). 


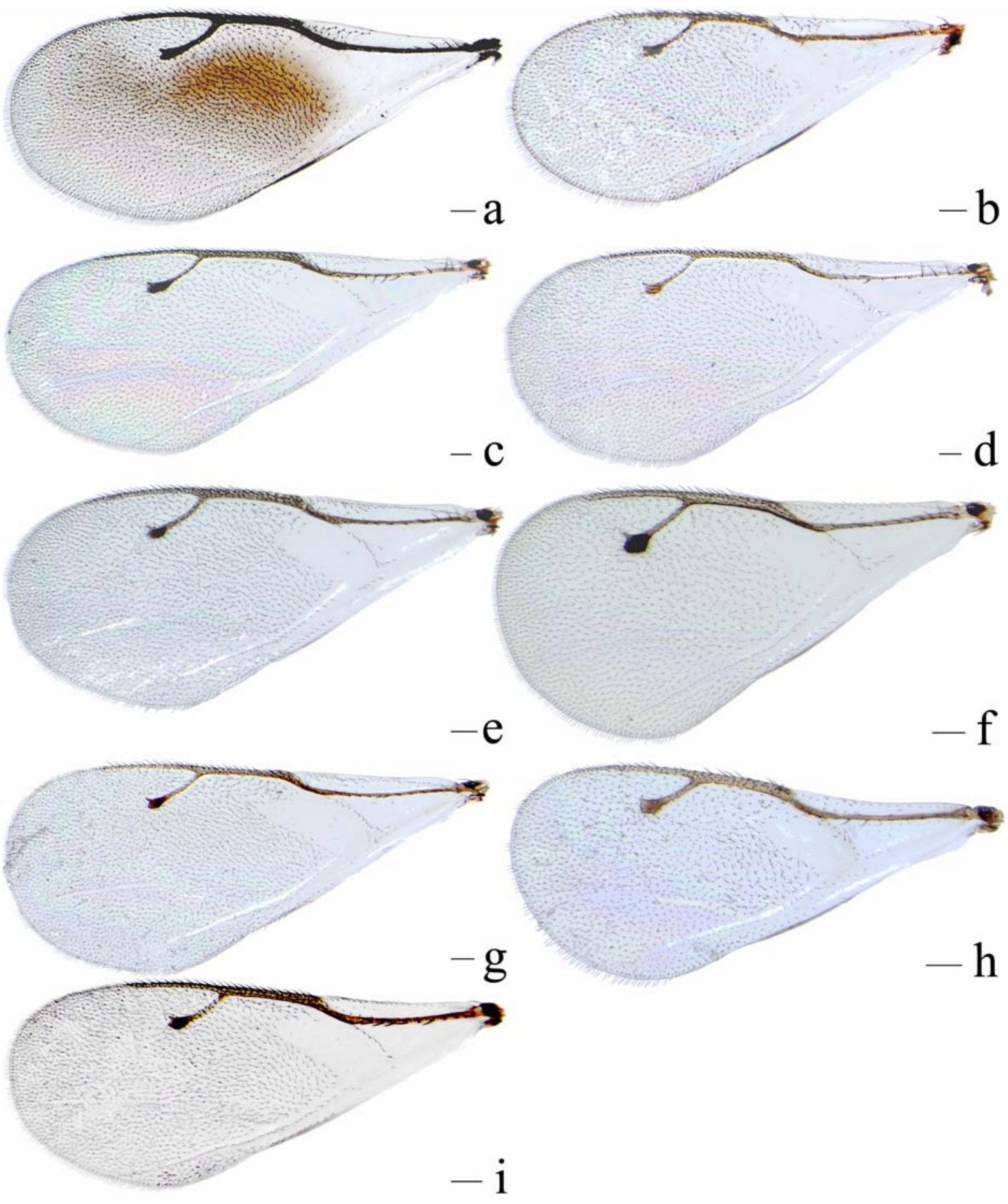

Fig. 2. Forewings of (a) $q$ Trichomalus campestris (Walker, 1834); (b) $\lesssim$ T. campestris; (c) $q$ Trichomalus lucidus (Walker, 1835); (d) §T. lucidus; (e) $\varnothing$ Trichomalus perfectus (Walker,

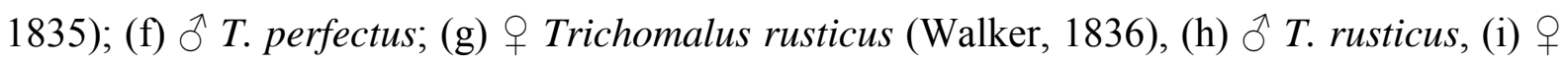
Trichomalus bracteatus (Walker, 1835). Scale bars $=100 \mu \mathrm{m}$. 


\section{Material examined:}

FRANCE. Hérault: S-Guilhem-le-Désert, Les Lavagnes; coll. 30.III.2002; leg. H. Baur (1). ITALY. Novara: $0.9 \mathrm{~km}$ E of Orta; 678.0/72.4, coll. 24.6.1993; leg. H. Baur $(1 \propto ; 1$ đ). Varallo, $0.5 \mathrm{~km} \mathrm{~S}$ of Monte Novesso; 668.8/77.0, coll. 27.6.1993; leg. H. Baur (3 ठే). ROMANIA. Lasi, RO12 N47¹0.139 E02728.035; coll. 12.V.2003, em. 2.-4.VII.2003; leg M. Cripps; indiv. reared from Ceutorhynchus cardariae in root-crown galls of Lepidium draba L. (2ð’; 19). SWITZERLAND. Berne: Berne, Eymatt, 596.7/201.4; coll. 20.V.2004; leg. H. Baur (3 q); Bremgarten, Hoger, 599.4/202.9; coll. 12.V.1992; leg. H. Baur (1 ); coll. 26.V.2004; leg. H. Baur (3 +). Solothurn: Rickenbach, 631.2/244.2; coll. 10.X.1995; leg. H. Baur (19); Trimbach, Miesernbach, 632.9/246.2; coll. 25.4.2002; leg. H. Baur (2)). Valais. Baltschieder-Kumme; coll. 3.4.1999; leg. B. Merz (1 9 ); Simplon, Laggintal, 548.5/113.3; coll. 21.9.1998; leg. H. Baur (1ठ). UKRAINE. Crimea: Shchebetovka, N4457.180 E03507.936; coll. 17.V.2003, em. 8.VI.2003; leg. M. Cripps; indiv. reared from Ceutorhynchus cardariae in root-crown galls of Lepidium draba L. (1+)

\section{Diagnosis:}

Female. Length 1.8-2.3 mm (Fig. 7a). Antenna in lateral view with first funicular segment about as broad as pedicel. Procoxa testaceous (Fig. 1b). Fore wing often with a dark discal cloud (Fig. 2a); marginal vein 1.1-1.5 x as long as stigmal vein (Fig. 2a); stigma small; basal fold bare; costal cell with setal line on lower surface widely interrupted medially. Metacoxa densely setose dorsobasally (see Fig. 4e). Propodeum with median area $1.45-1.6 \mathrm{x}$ as broad as long, weakly sculptured. Gaster about $1.4-1.6 \mathrm{x}$ as long as mesosoma and 1.7-2.1 $\mathrm{x}$ as long as broad; length of last tergite $0.8-0.9 \mathrm{x}$ its basal breadth (Fig. 5a).

Male. Length 1.4-1.7 mm (Fig. 7d). Procoxae testaceous (see Fig. 1b). Antenna with scape testaceous (Fig. 3e), broadest medially, only about $3 \mathrm{x}$ as long as broad and 1.0-1.2 $\mathrm{x}$ as long as eye height; flagellum dark with funicular segments $4-6$ or 5 and 6 testaceous (Fig. 3e). Gena rounded near base of mandible (see Fig. 6a). Pronotal collar distinctly narrower than mesoscutum (see Fig. 8a), its anterior margin rather strongly curved viewed from behind. Fore wing with marginal vein $1.2-1.35 \mathrm{x}$ as long as stigmal vein (Fig. 2b); basal fold bare, costal cell with setal line on lower surface widely interrupted medially; stigma small. 
Metacoxa densely setose dorsobasally. Propodeum about half as long as scutellum. Gaster with a pale transverse band basally (Fig. 5b).
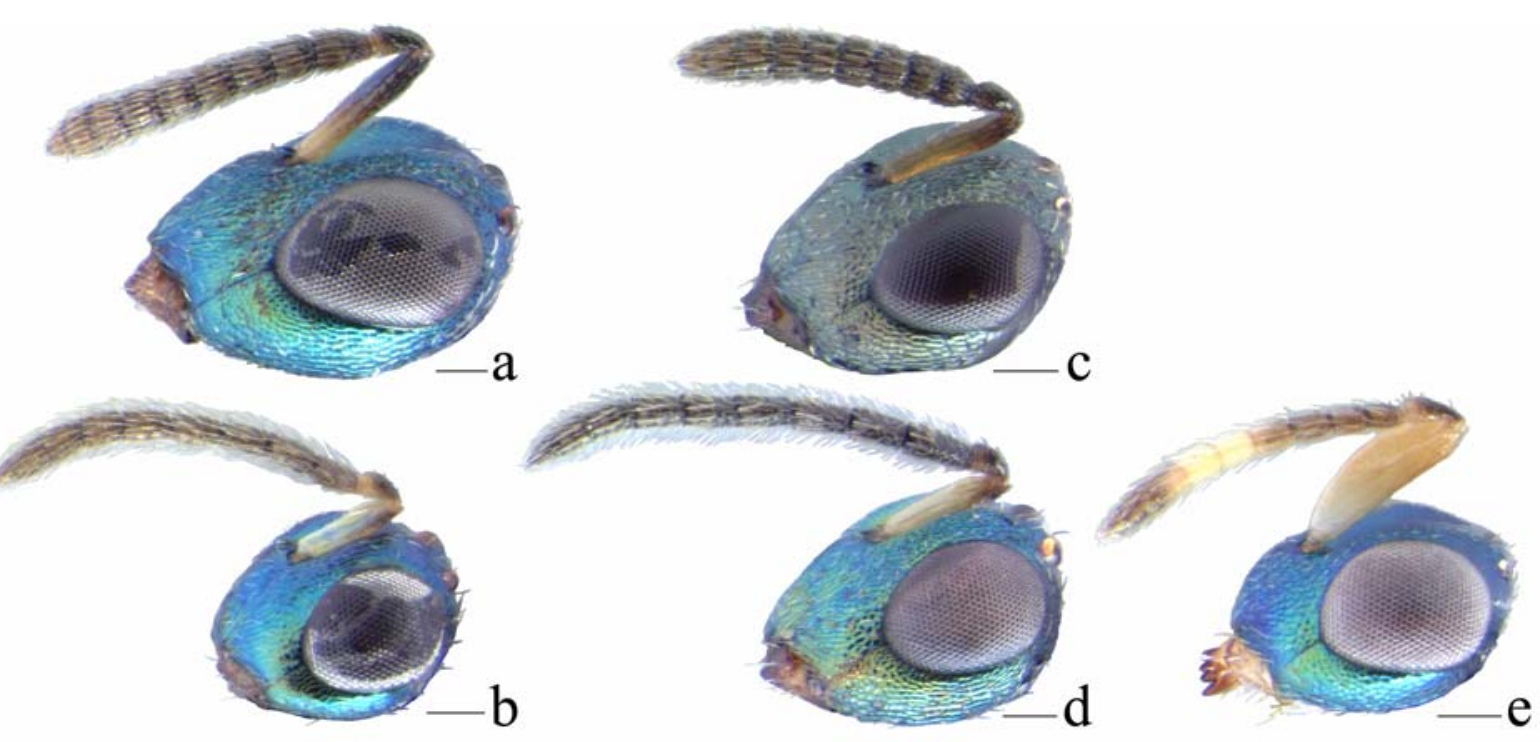

Fig. 3. Head and antennae (front-lateral) of (a) + Trichomalus lucidus (Walker, 1835); (b) $\widehat{\varnothing}$

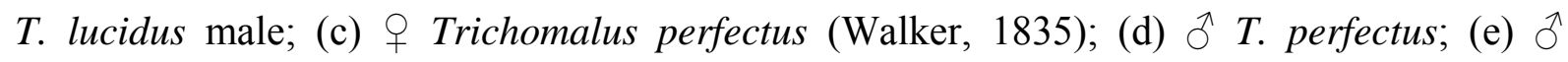
Trichomalus campestris (Walker, 1834). Scale bars $=100 \mu \mathrm{m}$.

\section{Remarks:}

Yellowish procoxae readily differentiate both sexes of T. campestris from other Trichomalus associated with Ceutorhynchus species. Females are often also differentiated by having the forewing infumate behind the marginal vein, and males by structure of their scape, and antennal and gastral colour pattern. Our rearing of T. campestris from Ceutorhynchus cardariae in root-crown galls of Lepidium draba L. represents a new host record for the species.

\section{Trichomalus gynetelus (Walker, 1835)}

\section{Type material:}

Pteromalus gynetelus Walker, 1835, lectotype female (B.M. TYPE HYM. 5.1767) in BNHM, designated by Graham (Graham, 1956a); paralectotypes 4 female (BMNH) (examined by Baur). 

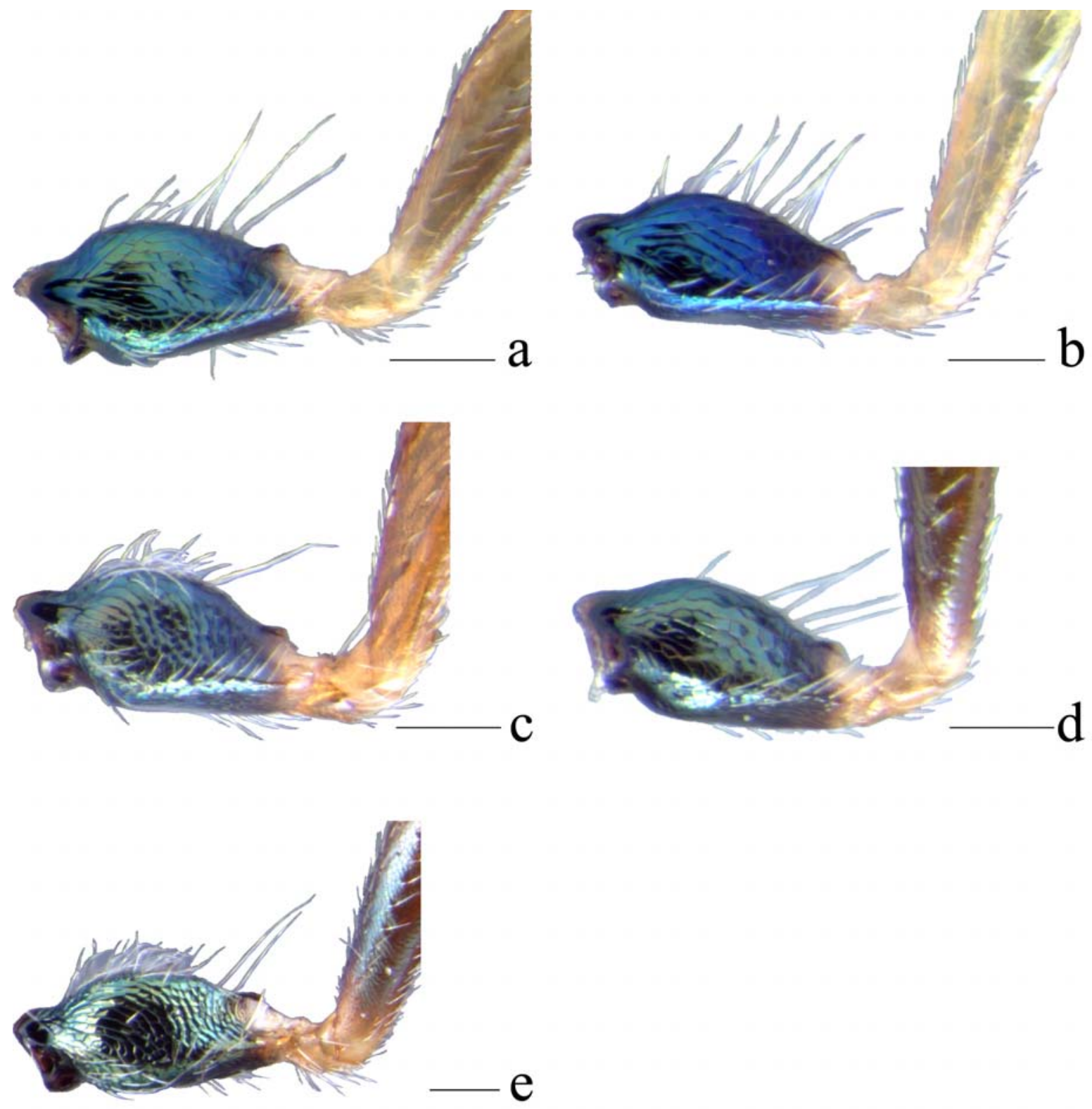

Fig. 4. Metacoxae (lateral) illustrating differences in pilosity for (a) $q$ Trichomalus lucidus (Walker, 1835); (b) §̂ T. lucidus; (c) † Trichomalus perfectus (Walker, 1835); (d) + Trichomalus bracteatus (Walker, 1835); (e) OTrichomalus rusticus (Walker, 1836). Scale bars $=100 \mu \mathrm{m}$.

\section{Material examined:}

AUSTRIA. Eisenstadt, AUS-EIS2; coll. 15.VI.2003; leg. F. Muller; indiv. reared ex. Microplontus (Ceutorhynchus) edentulus Schultze in stems of Tripleurospermum perforatum (Mérat) Laínz (Asteraceae: Anthemideae) (19). CZECH REPUBLIC. Bohemia: PrahaButovice, Prokopskè Udoli, N50.02.609 E014.21.348, 100m; coll. 7.VI.2004; leg. H. Baur (NMBE); collected by sweeping (1q). SWITZERLAND. Valais: NE Hohtenn (subalpline 
Weide) 625.65/130.75, 1460m; coll. 30.VI.1992; leg. H. Baur (NMBE); collected by sweeping (19). Fully, Les Follatères, 571.6/108.0, 620m; coll. 18.VI.2004; leg. H. Baur (NMBE); collected by sweeping (1+). Jura: La Chaud-des-Breuleux, La Baumatte, 569/230, 1100m; coll. 18.VII.1996; leg. H. Baur (NMBE); collected by sweeping (1 ).

\section{Diagnosis:}

Female. Length 2.4-3.1 mm (Fig. 7h). Antenna in lateral view with first funicular segment at most slightly broader than pedicel. Procoxae dark green with metallic tinge, similar to body. Forewing hyaline (see Fig. 2a); marginal vein 1.6-2.0 x as long as stigmal vein; stigma of medium size; basal fold and lower side of costal cell with complete setal lines. Metacoxa sparsely setose dorsobasally (see Fig. 4c). Propodeum with median area 1.65-1.95 x as broad as long, from almost smooth to slightly strigose. Gaster $1.7-1.95 \mathrm{x}$ as long as mesosoma and 2.9-3.4 $\mathrm{x}$ as long as broad; length of last tergite about 1.7-2.15 $\mathrm{x}$ its basal breadth.

Male. See characters given in the key.

\section{Remarks:}

See T. bracteatus.

\section{Trichomalus lucidus (Walker, 1835)}

\section{Type material:}

Pteromalus lucidus Walker, 1835, lectotype female (B.M. TYPE HYM. 5.3394) in BMNH, designated by Graham (Graham, 1956a) (specimen glued on card rectangle, head and mesosoma with strong coppery tinges; metacoxae covered with glue, hence some setae probably worn off; however, only few pores of setae present) (examined by Baur).

Pteromalus brevicornis Walker, 1835, lectotype female (B.M. TYPE HYM. 5.1772) in BMNH, designated by Graham (Graham, 1956a) (specimen glued on card rectangle, head and mesosoma with strong coppery tinges) (examined by Baur). 

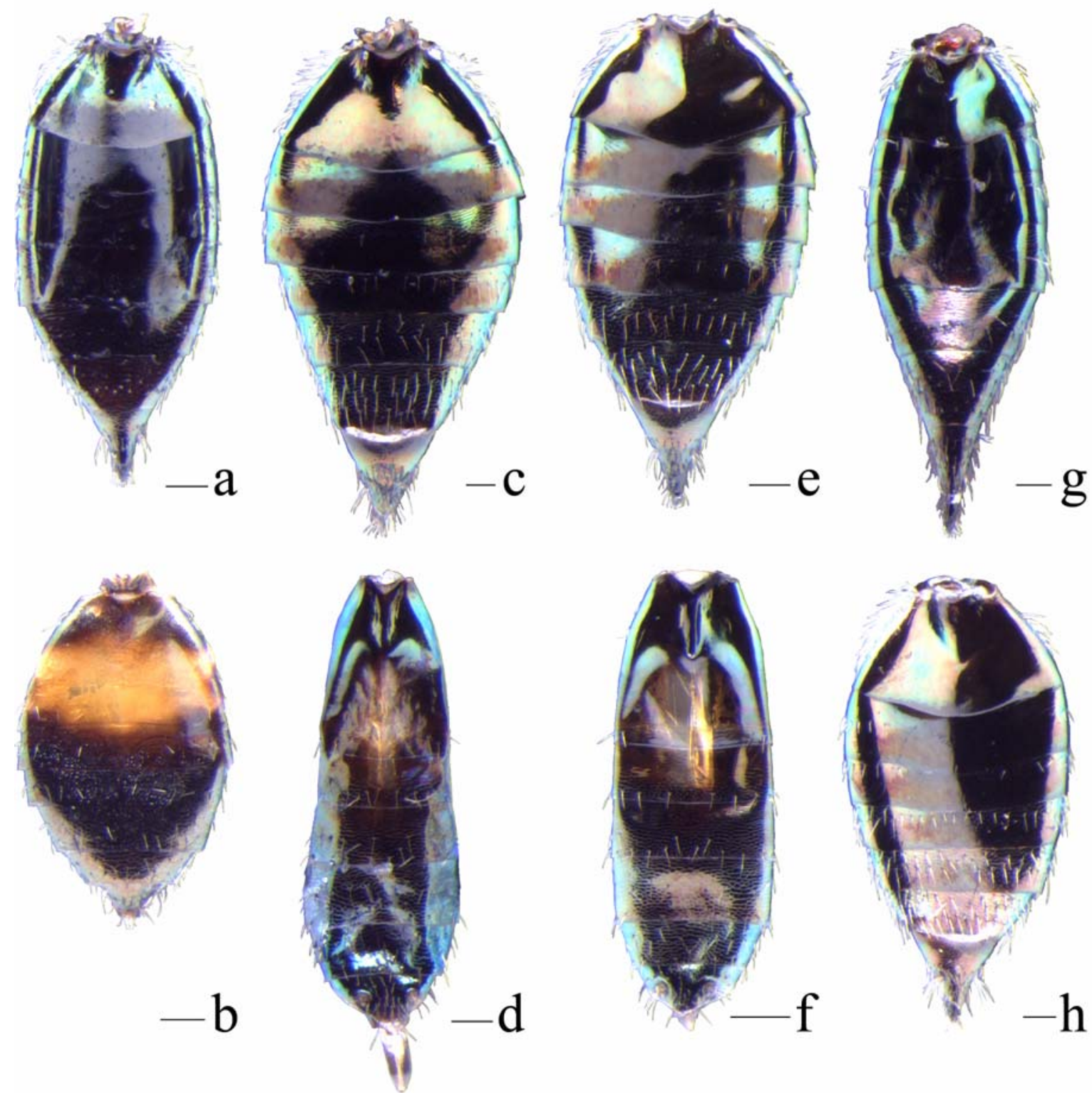

Fig. 5. Metasoma (dorsal) of (a) $q$ Trichomalus campestris (Walker, 1834); (b) $\lesssim T$. campestris; (c) † Trichomalus lucidus (Walker, 1835); (d) đ̂ T. lucidus; (e) ๆ Trichomalus perfectus (Walker, 1835); (f) đ̂ T. perfectus; (g) ๆ Trichomalus bracteatus (Walker, 1835); (h) $\uparrow$ Trichomalus rusticus (Walker, 1836). Scale bars $=100 \mu \mathrm{m}$.

Pteromalus chalceus Walker, 1835, lectotype female (B.M. TYPE HYM. 5. 1770) in BMNH, designated by Graham (Graham, 1956a) (specimen glued on card rectangle) (examined by Baur). 
Pteromalus despectus Walker, 1835, lectotype female (B.M. TYPE HYM. 5.1771) in BMNH, designated by Graham (Graham, 1956a) (specimen glued on card rectangle) (examined by Baur).

Pteromalus mundus Förster, 1841, lectotype male in Natural History Museum, Vienna, Austria, designated by Graham (Graham, 1956a) (not examined; primary homonym of P. mundus Walker, 1836).

Isocyrtus (Trichomalus) fasciatus Thomson, 1878, lectotype female in Zoological Museum, Lund University, Lund, Sweden, designated by Graham (Graham, 1956a) (not examined).

Pteromalus purus Dalla Torre, 1898, replacement name for Pteromalus mundus Förster, 1841, not Walker, 1836.

\section{Material examined:}

GERMANY. Baden-Württemberg: Rheintal, Müllheim; coll. 2000, leg. B. Klander; indiv. reared, ex. Ceutorhynchus roberti Gyllenhal 1837 in stems of Alliaria petiolata (M. Bieb.) Cavara \& Grande (1ठ); Neuenburg; coll. 31.V.2001 \& 19.VI.2001; leg. B. Klander; indiv. reared, ex. Ceutorhynchus roberti Gyllenhal 1837 in stems of Alliaria petiolata (M. Bieb.) Cavara \& Grande (2犬; 2q); Zienken; coll. 2000; leg. B. Klander; indiv. reared, ex. Ceutorhynchus roberti Gyllenhal 1837 in stems of Alliaria petiolata (M. Bieb.) Cavara \& Grande (1ठ̂). Brandenburg-Berlin: Berlin, Schoenebeck; coll. 2.VI.2001; leg. M. Grossrieder; indiv. reared, ex. Ceutorhynchus alliariae Gyllenhal in stems of Alliaria petiolata (M. Bieb.) Cavara \& Grande (1つ̋; 1ㅇ); coll. 5.VI.2001; leg. M. Grossrieder; indiv. reared, ex. Ceutorhynchus scrobicollis Nerensheimen \& Wagner in stems of Alliaria petiolata (M. Bieb.) Cavara \& Grande (1ठ; 1q). Brandenburg; coll. 19.-30.V.2001; leg. M. Grossrieder; indiv. reared, ex. Ceutorhynchus alliariae Gyllenhal in stems of Alliaria petiolata (M. Bieb.) Cavara \& Grande (2ふ̂); coll. 19.-25.V.2001; leg. M. Grossrieder; indiv. reared, ex. Ceutorhynchus scrobicollis Nerensheimen \& Wagner in stems of Alliaria petiolata (M. Bieb.) Cavara \& Grande (1§̋; 1 ) ). Schleswig-Holstein: Griebel; coll. 28.VI.2001; leg. M. Grossrieder; indiv. reared, ex. Ceutorhynchus alliariae Gyllenhal in stems of Alliaria petiolata (M. Bieb.) Cavara \& Grande (1 +). Hotzkaten; coll. 2000; leg. M. Grossrieder; indiv. reared, ex. Ceutorhynchus alliariae Gyllenhal in stems of Alliaria petiolata (M. Bieb.) Cavara \& Grande (1乞ึ). SWITZERLAND. Baselland: Grellingen; coll. 30.V.-26.VI.2001, leg. M. Grossrieder; indiv. reared, ex. Ceutorhynchus roberti Gyllenhal 1837 in stems of Alliaria 

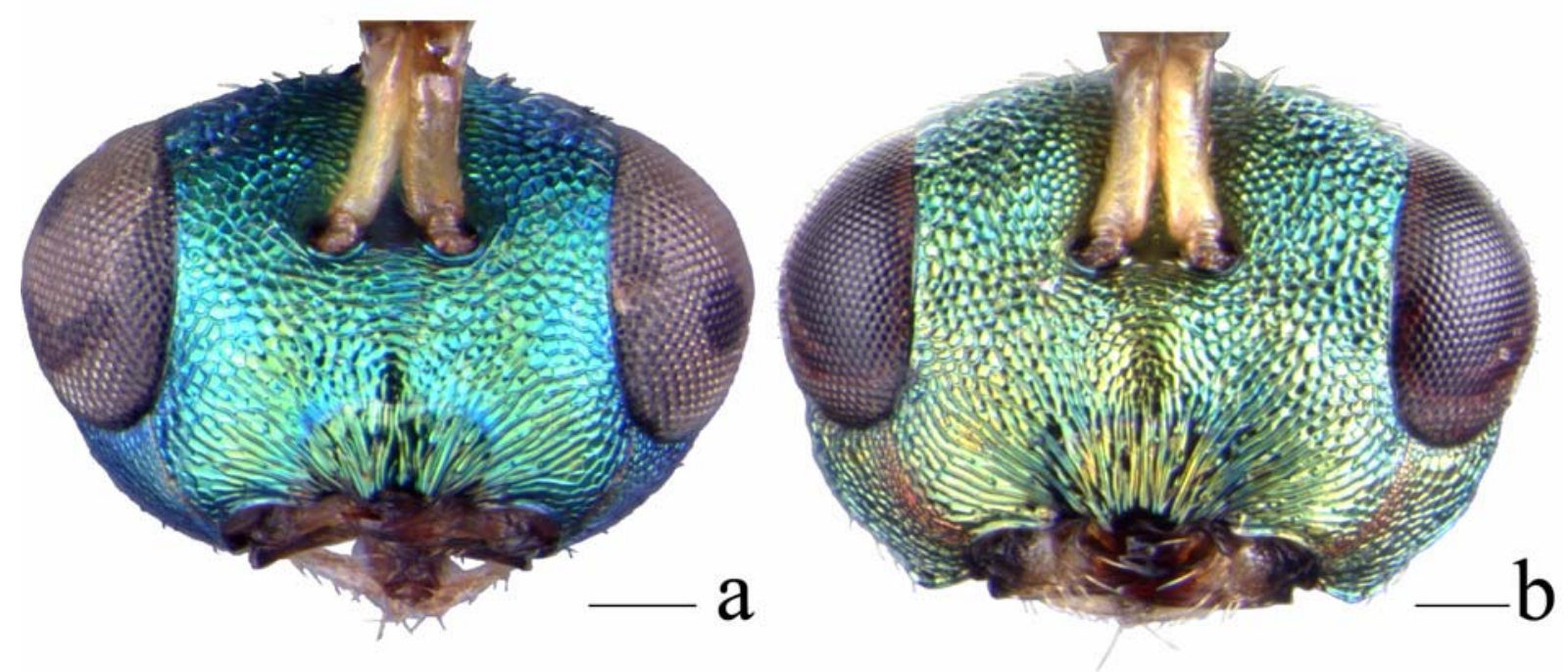

Fig. 6. Head (baso-lateral) illustrating differences in the shape of gena in $\hat{\sigma}$ of (a) Trichomalus lucidus (Walker, 1835) and (b) Trichomalus perfectus (Walker, 1835). Scale bars $=100 \mu \mathrm{m}$.

petiolata (M. Bieb.) Cavara \& Grande (38ð’; 19우). Fribourg: Sugiez; coll. 19.VI.2000, leg. M. Grossrieder, ex Ceutorhynchus quadridens in cabbage $(1 \uparrow ; 1 \overbrace{}^{\Uparrow})$. Jura: Delemont; coll. 18.VI.2002, leg. F. Muller; indiv. reared, ex. Ceutorhynchus alliariae or C. roberti Gyllenhal 1837 in stems of Alliaria petiolata (M. Bieb.) Cavara \& Grande (19); same, coll. 30.V.2002 $\left(1{ }^{\Uparrow}\right)$ and coll. 3.VI.2002 (1ठ); Delemont, Vorbourg; coll. 5.VI.2001, leg. M. Grossrieder; indiv. reared, ex. Ceutorhynchus roberti Gyllenhal 1837 in stems of Alliaria petiolata (M. Bieb.) Cavara \& Grande (2ð); Undevelier; coll. 25.V.2001, leg. M. Grossrieder; indiv. reared, ex. Ceutorhynchus roberti Gyllenhal 1837 in stems of Alliaria petiolata (M. Bieb.) Cavara \& Grande $\left(1 \jmath^{\Uparrow}\right)$.

\section{Diagnosis:}

Female. Length 2.5-3.1 mm (Fig. 7b). Antenna in lateral view with first funicular segment at most slightly broader than pedicel (Fig. 3a). Forewing hyaline (Fig. 2c); marginal vein 1.7$2.0 \mathrm{x}$ as long as stigmal vein (Fig. 2c); stigma small; basal fold and lower side of costal cell with complete setal lines. Procoxae dark green with metallic tinge, similar to body (see Fig. 1a). Metacoxa sparsely setose dorsobasally (Fig. 4a). Propodeum 1.25-1.4 x as broad as long, median area weakly sculptured. Gaster $1.25-1.4 \mathrm{x}$ as long as mesosoma and 2.1-2.4 x as long as broad; length of last tergite about $0.7-0.9 \mathrm{x}$ its basal breadth (Fig. 5c). 
Male. Length 1.9-2.5 mm (Fig. 7e). Procoxae dark (see Fig. 1a). Antenna with scape testaceous, distinctly expanded apically (Fig. 3b), about $4 \mathrm{x}$ as long as broad and about $0.75 \mathrm{x}$ eye height; flagellum dark. Gena rounded near base of mandible (Fig. 6a). Pronotal collar almost as broad as mesoscutum (see Fig. 8b), its anterior margin rather strongly curved when viewed from behind. Fore wing with marginal vein $1.55-1.8 \mathrm{x}$ as long as stigmal vein; basal fold and lower side of costal cell with complete setal lines (Fig. 2d); stigma small. Metacoxa sparsely setose dorsobasally (Fig. 4b). Propodeum about half as long as than scutellum. Gaster with a pale spot basally (Fig. 5d).

\section{Remarks:}

Of the lectotypes listed above that we examined, all agree well with the diagnosis of $T$. lucidus and are therefore considered conspecific. We accept the synonymy of Graham (1969) for the other names. Females of T. lucidus and T. rusticus are very similar, as discussed under the latter species.

\section{Trichomalus perfectus (Walker, 1835)}

\section{Type material:}

Pteromalus perfectus Walker, 1835, lectotype female (B.M. TYPE HYM. 5.1798) in BMNH, designated by Graham (1956) (examined by Gibson).

\section{Material examined:}

FRANCE. Alsace: Faverois, FAV, N47.518947 EO7.053317; coll. 6.VII.204; leg. F. Muller; Mass. Coll, ex. Ceutorhynchus obstrictus in pods of Brassica napus L.(7ð̄; 10ํ); indiv. reared from larval parasitoids, ex. Ceutorhynchus obstrictus in pods of Brassica napus L.(2犬; 3 ㅇ); Boron, BRN3, N47.536484 E07.006693; coll. 21.VI.2004; leg. F. Muller, indiv. reared from larval parasitoids, ex. Ceutorhynchus obstrictus in pods of Brassica napus L (19). GERMANY. Schleswig-Holstein: Rastorfer Passau, RP, N54.283 E10.350; coll. 3.28.VI.2002 \& 1.-10.VII.2002; leg. F. Muller, indiv. reared from larval parasitoids, ex. Ceutorhynchus obstrictus in pods of Brassica napus L. (15つ̋; 7ㅇ); Kiel, coll. 24.VI.1999, leg. B. Klander ex. Ceutorhynchus obstrictus in pods of Brassica napus L. (1 9 ); same, coll. 

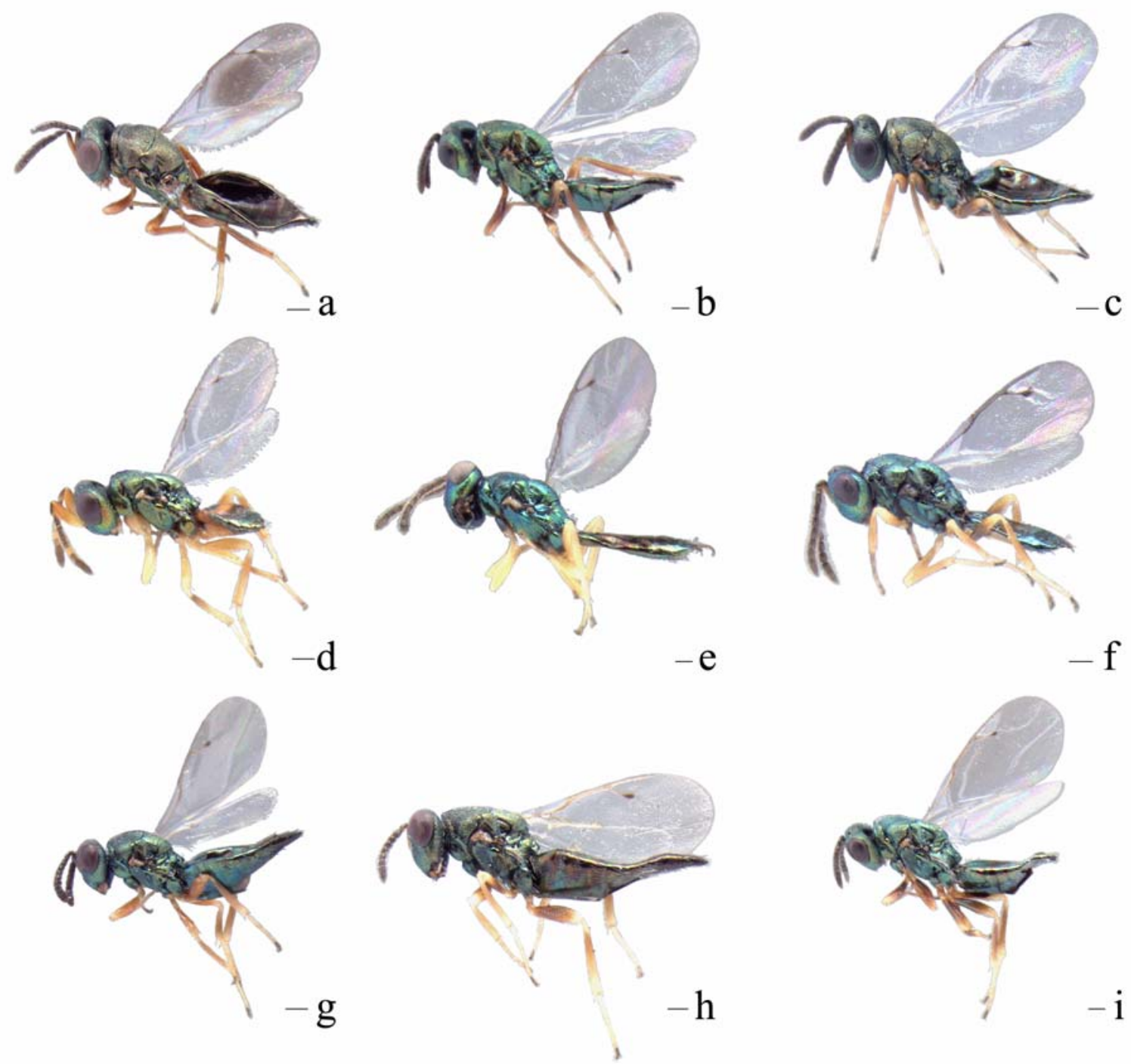

Fig. 7. Habitus of (a) 9 Trichomalus campestris (Walker, 1834); (b) $\subsetneq$ Trichomalus lucidus (Walker, 1835); (c) q Trichomalus perfectus (Walker, 1835); (d) § T. campestris, (e) ઈิ T. lucidus, (f) đ̊ T. perfectus, (g) † Trichomalus bracteatus (Walker, 1835); (h) $\varnothing$ Trichomalus Gynetulus (Walker, 1835), (i) q Trichomalus rusticus (Walker, 1836). Scale bars $=100 \mu \mathrm{m}$.

5.VI.2000 (2今). SWITZERLAND. Jura: Chatillon, La Prîre, CHA11, N47.334285 E07.332301; coll. 8.VI.2004; leg. F. Muller; indiv. reared from larval parasitoids, ex. Ceutorhynchus obstrictus in pods of Brassica napus L. (19); CHA12, N47.329621 E07.331510; coll. 22.VI.2004; leg. F. Muller; indiv. reared from larval parasitoids, ex. Ceutorhynchus obstrictus in pods of Brassica napus L. (1ठ); CHA14, N47.338940 E07.332363; coll. 15.VI.2004; leg. F. Muller; indiv. reared from larval parasitoids, ex. Ceutorhynchus obstrictus in pods of Brassica napus L. (2ङ);CHA-LP2; coll. 20.VI.2003; leg. 
F. Muller; indiv. reared from larval parasitoids, ex. Ceutorhynchus obstrictus in pods of Brassica napus L. .(1§ో; 6우); coll. 28.VI.2002; leg. F. Muller; indiv. reared from larval parasitoids, ex. Ceutorhynchus obstrictus in pods of Brassica napus L. (1ðં; 1); CHA-LP3; coll. 9.-25.VI.2002 \& 1.VII.2002; leg. F. Muller; indiv. reared from larval parasitoids, ex. Ceutorhynchus obstrictus in pods of Brassica napus L. (8今゙; 3 +); CHA-1, coll. 9., 18.,19., 22., 26. \& 28.VI.2002 \& 1.VII.2003, leg. F. Muller; indiv. reared from larval parasitoids, ex. Ceutorhynchus obstrictus in pods of Brassica napus L. (7ô; 6ㅇ); Delémont, Le Chavelier DEL-DOM; coll. 10.-13. \& 20.VI.2003; leg. F. Muller; indiv. reared from larval parasitoids, ex. Ceutorhynchus obstrictus in pods of Brassica napus L. (11§亍; 5q); Courgenay, CGY1, N47.404000 E07.156737; coll. 21.VI.2004, leg. F. Muller; indiv. reared from larval parasitoids, ex. Ceutorhynchus obstrictus in pods of Brassica napus L. $\left(1 \frac{1}{3}\right)$. Fribourg: Galmiz, Gal, N46.989 E07;100; coll. 28.VII.2004; leg. F. Muller; indiv. reared from larval parasitoids, ex. Ceutorhynchus obstrictus in pods of Brassica napus L. (1 §̋; 1 + ).

\section{Diagnosis:}

Female. Length 1.65-2.9 mm (Fig. 7c). Antenna in lateral view with first funicular segment distinctly broader than pedicel (Fig. 3c). Procoxae dark green with metallic tinge, similar to body (see Fig. 1a). Forewing hyaline (Fig. 2e); marginal vein 1.35-1.5 x as long as stigmal vein (Fig. 2e); stigma of medium size, on average slightly larger than in T. lucidus (see Fig. 2c, e); basal fold and lower side of costal cell with complete setal lines. Metacoxa densely setose dorsobasally (Fig. 4c). Propodeum with median area 1.45-1.6 x as broad as long, strigose-reticulate. Gaster $1.2-1.4 \mathrm{x}$ as long as mesosoma and 1.8-2.1 x as long as broad; length of last tergite $0.8-0.95 \mathrm{x}$ its basal breadth (Fig. 5e).

Male. Length 1.6-2.2 mm (Fig. 7f). Procoxae dark (see Fig. 1a). Antenna with scape testaceous, distinctly expanded apically (Fig. 3d), about $4 \mathrm{x}$ as long as broad and about $0.75 \mathrm{x}$ eye height; flagellum dark (Fig. 3d). Gena slightly compressed and with sharp edge near base of mandible (Fig. 6b). Pronotal collar almost as broad as mesoscutum (Fig. 8b), its anterior margin only weakly curved when viewed from behind. Fore wing with marginal vein 1.1-1.4 $\mathrm{x}$ as long as stigmal vein; basal fold and lower side of costal cell with complete setal lines (Fig. 2f); stigma relatively large. Metacoxa densely setose dorsobasally. Propodeum about half as long as scutellum. Gaster with a pale spot basally (Fig. 5f). 


\section{Remarks:}

Individuals of $T$. perfectus are differentiated from other species of Trichomalus associated with Ceutorhynchus species by a combination of features as given in the key.
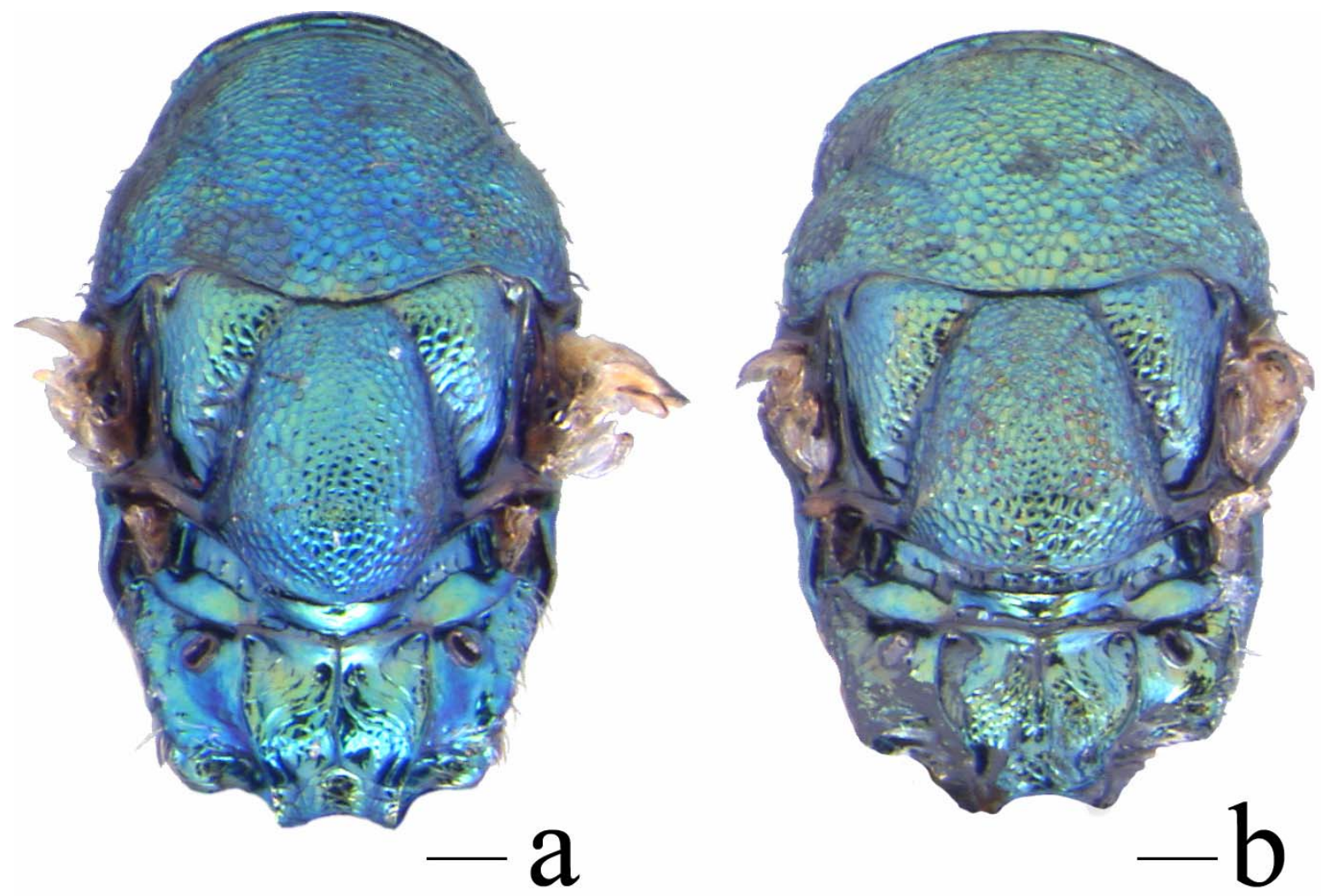

Fig. 8. Mesosoma (dorsal) illustrating differences in pronotal collars in $\widehat{\partial}$ of (a) Trichomalus lucidus (Walker, 1835) and (b) Trichomalus perfectus (Walker, 1835). Scale bars $=100 \mu \mathrm{m}$.

\section{Trichomalus rusticus (Walker, 1836) revised status}

\section{Type material:}

Pteromalus rusticus Walker, 1836, lectotype female (B.M. TYPE HYM. 5.3396) in BMNH, present designation; labelled "Pteromalus rusticus Walker; Stood under this name in old B. M. Coll. C. Waterhouse. [back side of former label]; Pteromalus rusticus W. LECTOTYPE M. de V. Graham 1956; B.M. TYPE HYM. 5.3396" (specimen glued on card rectangle, the right metacoxa and gaster lacking; badly covered with dust, color of legs and venation partly darkened and certainly an artefact) (examined by Baur). 
Pteromalus lyttus Walker, 1848, lectotype female (B.M. TYPE HYM. 5.1773) in BMNH, designated by Graham (Graham, 1956a) (specimen glued on card rectangle, body with rather strong coppery tinges) (examined by Baur) syn. $\mathbf{n}$.

\section{Material examined:}

SWEDEN. Akarp; coll. 17.I.1962; leg. H. Von Rosen (NMBE); collected by sweeping (1 9 ); Lomma; coll. 17.I.1962 \& 1.I.1964; leg. H. Von Rosen, collected by sweeping (5q). SWITZERLAND. Neuchatel: St-Blaise; coll. 10.IV.1978 \& 13.-16.IV.1979; leg. J. Casas (NMBE); collected by sweeping (6甲); Sugiez; coll. 19.VI.2000; leg. B. Klander (NMBE); found in cabbage, ex. Ceutorhynchus quadridens? (19). Solothurn: Hüniken, S Tannfeld; 20.IX.1993; leg. H. Baur (NMBE) (1 +).

\section{Diagnosis:}

Female. Length 2.3-2.9 mm (Fig. 7i). Antenna with scape dark in apical three quarters, pedicel and flagellum dark; scape $0.75-0.9 \mathrm{x}$ eye height; pedicel about $1.8 \mathrm{x}$ as long as broad in lateral view; pedicel plus flagellum $0.85-1.0 \mathrm{x}$ as long as head breadth; flagellum slender, slightly clavate; first funicular segment rather slender, about $1.25 \mathrm{x}$ as long as broad, only slightly broader than pedicel in lateral view; last funicular segment distinctly transverse, about $0.8 \mathrm{x}$ as long as broad. Head 2.1-2.2 $\mathrm{x}$ as broad as long, 1.2-1.35 $\mathrm{x}$ as long as mesoscutum, finely reticulate with minute and high meshes on vertex; POL 1.6-1.8 x OOL; eye 1.3-1.4 x as high as broad, separated by $1.25-1.4 \mathrm{x}$ their height; malar space $0.44-0.53 \mathrm{x}$ as long as eye height; clypeus striate, weakly emarginate medially. Body dark metallic green (Fig. 7i); legs testaceous except coxae concolorous with body and femora slightly dark. Mesosoma 1.6-1.7 $\mathrm{x}$ as long as broad. Pronotal collar about one seventh as long as mesoscutum length. Mesoscutum 1.45-1.55 $\mathrm{x}$ as broad as long, reticulate with sculpture consisting of small meshes anteriorly and larger ones posteriorly; scutellum $0.9-0.95 \mathrm{x}$ as broad as long, reticulate. Fore wing hyaline (Fig. 2g); marginal vein 1.6-1.8 $\mathrm{x}$ as long as stigmal vein; stigma small, separated by about 2.5-3.1 x its height from hind margin of postmarginal vein; basal fold and lower side of costal cell with complete setal lines; speculum open below. Metacoxa densely setose dorsobasally (Fig. 4e); metafemur about 3.8-4.4 x as long as broad. Propodeum with complete plicae, median area finely alutaceous, about $1.2-1.4 \mathrm{x}$ as long as broad and $0.5-0.6 \mathrm{x}$ as long as scutellum; costulae indicated laterally, sometimes complete; nucha weakly reticulate; callus moderately hairy. Gaster (1.3-) 1.5-1.9 x as long as broad 
(Fig. 5h) and 0.9-1.17 x as long as mesosoma, ovate and acuminate; length of last tergite about $0.55-0.8 \times$ its basal breadth; sides of basal tergite with conspicuous patch of whitish hairs basally.

Male. Unknown.

\section{Remarks:}

Pteromalus rusticus was listed by Graham (1969) among the synonyms of T. lucidus, but the lectotype designation was not published in that or any other paper (see Delucchi \& Graham, 1956; Graham, 1969). Hence the specimen is regarded as a syntype that is herewith designated as lectotype. As suggested by Graham (Graham, 1956a), T. rusticus is very similar to T. lucidus, but we consider it is a distinct species. Although males are unknown, females of T. rusticus can be differentiated from those of $T$. lucidus by the following features (features of T. lucidus in brackets): Femora, especially metafemur, infuscate in basal half [mostly testaceous]. Sculpture on vertex, mesoscutum and scutellum relatively strong, with high meshes [sculpture finer]. Marginal vein usually shorter, 1.6-1.8 $\mathrm{x}$ as long as stigmal vein [1.7-2.0 x]. Base of metacoxa with thick batch of setae, which extend somewhat to outer aspect of coxa [setae sparse and confined to dorsal aspect]. Gaster normally $1.5-1.9 \mathrm{x}$ as long as wide, however one specimen has a ratio of only 1.3 [about 2-2.4 x].

\section{Discussion}

Results of our study have direct implications for documenting ecological baseline data of parasitoid-Ceutorhynchinae host associations, which is essential to a renewed classical biological initiative against $C$. obstrictus in Canada. Trichomalus lucidus is confirmed as a parasitoid of C. alliariae and C. roberti, two candidate classical biological control agents against Alliaria petiolata (garlic mustard) (Gerber et al., 2003), which poses a severe threat to biodiversity of forest habitats (Blossey et al., 2002) in much of the eastern and Midwestern U.S.A. We did not rear T. lucidus from C. obstrictus in our surveys, though Klander (2001) reported that $1.7 \%$ of the parasitoids she reared from $C$. obstrictus on B. napus from Schleswig-Holstein, Germany, in 2000, were T. lucidus, and this species is purportedly one of the major parasitoids of C. obstrictus in North America (Gibson et al., 2005). Based on this 
apparent ecological difference, molecular analyses are warranted for specimens identified as T. lucidus in Europe and North America in order to test whether the populations actually represent two cryptic species. Also, for the first time we record T. campestris as a parasitoid of the gall-forming weevil C. cardariae, a potential agent for classical biological control of Lepidium draba (whitetop) in North America. We reared T. perfectus only from C. obstrictus, which is its main host; it has only rarely been recorded from other Ceutorhynchus spp. hosts in Europe (Klander, 2001). Consequently, this species could be considered for introduction to North America for classical biological control of C. obstrictus.

The number of concerns regarding potential non-target effects of invertebrate biological control agents of arthropods has risen during the last decade and an increasing number of studies have since dealt with this topic (Babendreier et al., 2005). However, understanding the population dynamics of Ceutorhynchinae species of economic importance is still hampered by the insufficient knowledge of the natural enemy complexes that may play an important role in the regulation of these herbivorous insects (Vidal, 2003). Clarification of the taxonomy of Trichomalus species presented here provides a sound basis for understanding these dynamics, leading towards the safe use of Trichomalus species in future biological control approaches against Ceutorhynchinae pest species. 


\section{Acknowledgments}

We acknowledge Emmanuel Cuenot (France), MSc Virginia Larraz (Spain), MSc Leonore Lovis (Switzerland), Gabor Nagy (Hungary), Fezekas Janos (Hungary), Alicia Leroux (Canada), MSc Tara Gariepy (Canada), Kim Riley (Canada), Lars Andreassen (Canada), MSc Leyla Valdivia Buitriago (Peru), MSc Rike Stelkens (Germany) and MSc Stephen Maggins (Ireland) for their precious help as part of the CABI Agricultural Pest Research dissection team. Maren Belde (Technischen Universität Munich, Germany) and MSc Beate Klander (Christian Albrechst Universtity, Kiel, Germany) for finding collection sites of Canada thistle in Germany. Dr. Scheibelreiter (Wien, Austria) assisted with collections of scentless chamomile in Austria in 2003. We appreciated the fruitful discussions with Dr. André Gassmann, Dr. Hariet Hinz, Dr. Stefan Toepfer and Dr. Esther Gerber (all CABI, Delémont) and acknowledge them as well for information exchanged on collection sites of scentless chamomile, hoary cress, Canada thistle, garlic mustard and other Ceutorhynchinae host plants in various European countries. This work was funded by Agriculture and Agri-Food Canada, and AAFC's Pest Management Research Centre Project PRR03-370 and the Alberta Agricultural Research Institute Reseach Institute. Technical support was provided by the Natural History Museum at Bern, Switzerland 


\section{References}

Babendreier, D., F. Bigler \& U. Kuhlmann (2005). Methods used to assess non-target effects of invertebrate biological control agents of arthropod pests. BioControl 50 (6), 821870 .

Blossey, B., V. A. Nuzzo, H. L. Hinz \& E. Gerber (2002). Garlic Mustard. In: R. Van Driesche, S. Lyon, B. Blossey, M. Hoddle and R. Reardon (Eds.) Biological control of invasive plants in the eastern United States. United department of agriculture - Forest health technology transfer team, Morgantown, West Virginia. 365-372.

Brodeur, J., L. Leclerc, M. Fournier \& M. Roy (2001). The cabbage seedpod weevil, Ceutorhynchus obstrictus (Coleoptera: Curculionidae): a new pest of canola in northeastern North America. The Canadian Entomologist 133 (5), 709-711.

Carcamo, H. A., L. M. Dosdall, M. Dolinski, O. Olfert \& J. R. Byers (2001). The cabbage seedpod weevil, Ceutorhynchus obstrictus (Coleoptera: Curculionidae) - a review. Journal of the Entomological Society of British Columbia 98, 201-210.

Colonnelli, E. (2004). Catalogue of Ceutorhynchinae of the world, with key to genera. Argania edito, Balmes, Barcelona. 124 pp.

Delucchi, V. \& M. W. R. Graham (1956). La révision du genre Trichomalus Thomson (1878) (Chalcidoidea: Pteromalidae). Beiträge zur Entomologie 6, 543-576.

Dieckmann, L. (1972). Beiträge zur Insektenfauna der DDR: Coleoptera - Curculionidae: Ceutorhynchinae. Beitrage zur Entomologie 22 (1/2), 3-128.

Dosdall, L. M., R. M. Weiss, O. Olfert \& H. A. Carcamo (2002). Temporal and geographical distribution patterns of the cabbage seedpod weevil (Coleoptera: Curculionidae) in canola. The Canadian Entomologist 134 (3), 403-418.

Gerber, E., H. L. Hinz, B. Blossey \& S. Bacher (2003). Two shoot miners as potential biological control agents for garlic mustard: should both be released? In: J. M. Cullen, D. T. Briese, D. J. Kriticoset al (Eds.) Proceedings of the XI International Symposium on Biological Control of Weeds. CSIRO. Canberra, Australia. 108-112.

Gibson, G. A. P., H. Baur, B. Ulmer, L. Dosdall \& F. J. Muller (2005). On the misidentification of the chalcid (Hymenoptera: Chalcidoidea) parasitoids of the cabbage seedpod weevil (Coleoptera: Curculionidae) in North America. The Canadian Entomologist 137, 381-403. 
Gibson, G. A. P., J. T. Huber \& J. R. Woolley (1997). Annotated Keys to the Genera of Nearctic Chalcidoidea (Hymenoptera). NRC Research Press, Ottawa. 772 pp.

Goulet, H. \& J. T. Huber (1993). Hymenoptera of the world: An identification guide to families. Research Branch Agriculture Canada, Ottawa, Ontario. 660 pp.

Graham, M. W. R. (1956). A revision of the Walker types of Pteromalidae (Hym., Chalcidoidea). Part 2 (including descriptions of new genera and species). Entomologist’s Monthly Magazine 92, 246-263.

Graham, M. W. R. (1969). The Pteromalidae of North-Western Europe (Hymenoptera: Chalcidoidea). Bulletin of the British Museum (Natural History) Entomology (Suppl.16), 908pp.

Julien, M. H. \& M. W. Griffiths (1998). Biological control of weeds - A world Catalogue of Agents and their target weeds. CABI Publishing, Wallingford, Oxon, UK. 223 pp.

Klander, B. (2001). Die Rüsselkäfer der Unterfamilie Ceutorhynchinae und deren parasitoide auf Winterraps und begleitenden Unkräutern in Schleswig-Holstein. MSc Thesis. Zoologisches Institut der Christian-Albrechts-Universität zu Kiel, Department of Ecology, Kiel, Germany.

Kuhlmann, U., L. M. Dosdall \& P. G. Mason (2002). Ceutorhynchus obstrictus (Marsham), cabbage seedpod weevil (Coleoptera: Curculionidae). In: P. G. Mason and J. T. Huber (Eds.) Biological Control Programmes in Canada, 1981-2000. CABI Publishing, Wallingford, Oxon, U.K. 52-58.

Mason, P. G., T. Baute, O. Olfert \& M. Roy (2003). Cabbage Seedpod Weevil, Ceutorhynchus obstrictus (Marsham) (Coleoptera:Curculionidae) in Ontario and Quebec. Journal of the Entomological Society of Ontario 134, 107-113.

Mason, P. G. \& J. T. Huber (Eds.) (2002). Biological control programmes in Canada, 19812000. CABI Publishing, Wallingford, UK. 583 pp.

McLeod, J. H. (1953). Notes on the cabbage ceedpod weevil, Ceutorhynchus assimilis (Payk.) (Coleoptera : Curculionidae), and its parasites. Entomological Society of British Columbia, Proc. 49, 11-18.

McLeod, J. H. (1962). Part 1 - Biological control of pests of crops, fruit trees, ornamentals, and weeds in Canada up to 1959. In: A review of the biological control attempts against insects and weeds in Canada. Commonwealth Agricultural Bureaux, Farnham, Bucks, UK. 216.

Murchie, A. K. \& I. H. Williams (1998). A bibliography of the parasitoids of the cabbage seed weevil (Ceutorhynchus assimilis Payk.). IOBC wprs Bulletin 21 (5), 163-169. 
Vidal, S. (2003). Identification of Hymenopterous parasitoids associated with oilseed rape pests. In: D. V. Alford (Ed.) Biocontrol of Oilseed Rape Pests. Blackwell Science, Oxford.161-179

Williams, I. H. (2003). Parasitoids of Cabbage Seed Weevil. In: D. V. Alford (Ed.) Biocontrol of Oilseed Rape Pests. Blackwell Science, Oxford. 97-112. 


\title{
A Review of the Species of Mesopolobus (Chalcidoidea:
}

\section{Pteromalidae) Associated with Ceutorhynchus (Coleoptera: \\ Curculionidae) Host-Species of European Origin.}

\author{
Hannes Baur ${ }^{1}$, Franck J. Muller ${ }^{2}$, Gary A. P. Gibson ${ }^{3}$, Peter G. Mason ${ }^{3}$ \& Ulrich Kuhlmann ${ }^{2}$
}

1- Naturhistorisches Museum, Bernstrasse 15, CH-3005 Bern, Switzerland

2- CABI Switzerland Centre, Rue des Grillons 1, 2800 Delémont, Switzerland

3- AAFC, Biodiversity and IPM, Research Centre, 960 Carling Avenue, Ottawa, Canada

\begin{abstract}
Four species of Mesopolobus Westwood, 1833, were reared as parasitoids of Ceutorhynchinae hosts in Europe during surveys in 2000-2004. An illustrated key is given to differentiate the four species (M. gemellus Baur\&Muller sp. nov., M. incultus (Walker, 1834), M. morys (Walker, 1848), and M. trasullus (Walker, 1848)) except for males of M. trasullus. Mesopolobus morys is for the first time accurately associated with the seed weevil Ceutorhynchus turbatus (Schultze), a potential agent for classical biological control of hoary cress, Lepidium draba L. [Asteraceae] in North America. Mesopolobus gemellus is for the first time associated with another seed weevil, Ceutorhynchus typhae (=C. floralis) (Herbst). Furthermore, implications of the host-parasitoid associations recovered by the surveys are discussed relative to introduction of species to North America for classical biological control of the cabbage seedpod weevil, Ceutorhynchus obstrictus (Marsham) [=C. assimilis (Paykull); see Colonnelli (2004)].
\end{abstract}




\section{Introduction}

In the last two decades increasing concerns have been expressed regarding potential nontarget effects of invertebrate biological control agents of arthropods (Howarth, 1991; Simberloff \& Stiling, 1996; Thomas \& Willis, 1998; Stiling \& Simberloff, 2000; Louda, 2003; Stiling, 2004). This has led to an increasing number of studies investigating non-target effects in many systems and several matters have recently been addressed with the aim of standardizing methods in risk assessment studies worldwide (Babendreier et al., 2005; Simberloff, 2005; Wright et al., 2005; Kuhlmann et al., 2006b). Undoubtedly, understanding the many trophic relationships between parasitic wasps used in classical biological control programmes, the target pest species they are aimed at, and potential non-target species is a key requirement prior to any introduction of candidate parasitoids. One of the many constraints biological control practitioners very frequently encounter is that the taxonomy of the involved groups is often unclear (Van Driesche \& Reardon, 2004).

The subfamily Ceutorhynchinae is the most speciose of the family Curculionidae, itself the most diverse family of Coleoptera (Colonnelli, 2004). Ceutorhynchinae contains about 1,316 species among which a certain number is considered to be herbivorous pests of high economic importance in agricultural crops (Dieckmann, 1972; Mason \& Huber, 2002). A number of Ceutorhynchus species such as the cabbage seedpod weevil, Ceutorhynchus obstrictus (Marsham) [=C. assimilis (Paykull); see Colonnelli (2004)], the cabbage stem weevil (Ceutorhynchus napi (Marsham)), the cabbage seedstalk curculio (Ceutorhynchus pallidactylus (Marsham)), and the turnip gall weevil (Ceutorhynchus pleurostigma Marsham) are pests of economic importance in cruciferous crops. Simultaneously, a number of Ceutorhynchinae species are used worldwide for classical biological control of weeds in crop and non-crop habitats (Julien \& Griffiths, 1998). In North America, Ceutorhynchinae released to reduce the impact of weed species include Mogulones crucifer (Pallas) for houndstongue Cynoglossum officinale (L.) [Boragincaceae] (De Clerck-Floate \& Schwarzlaender, 2002), Hadroplontus litura (Fabricius) for Canada thistle, Cirsium arvense (L.) Scopoli [Asteraceae] (McClay et al., 2002a), and Microplontus edentulus (Schultze) for scentless chamomile, Tripleurospermum perforatum (Merat) Lainz [Asteraceae] (McClay et al., 2002b). The 
existing interrelationships of pests and beneficial agents belonging to the same subfamily add one level of complexity to the work of biological practitioners.

The Chalcidoidea, one of the most important Hymenoptera groups, contains over 800 different species that have been associated with biological control programmes in one or another way (Noyes, 2006). A number of Mesopolobus (Chalcidoidea: Pteromalidae) species are known to be important members of parasitoid assemblages associated with several Ceutorhynchinae species (Murchie \& Williams, 1998). For instance, Mesopolobus morys Walker is one of the most important parasitoids involved in the cabbage seedpod weevil natural enemy complex in Europe (Williams, 2003). Ceutorhynchus obstrictus is a pest of oilseed rape, Brassica napus L., in Europe and was accidentally introduced in North America where it is now widespread (Kuhlmann et al., 2002). As an invasive alien species $C$. obstrictus has always been considered as a prime target for classical biological control (McLeod, 1962). In a first attempt at classical biological control of C. obstrictus, several larval ectoparasitoids, including $M$. morys were released into British Columbia in 1949 (McLeod, 1953). Later, McLeod (1962) reported that $M$. morys might have already been present, presumably accidentally introduced with $C$. obstrictus. Until very recently this species was considered to be established in North America although follow up studies were never conducted. Recently, the pest has been reported from the Canadian provinces of Alberta (Carcamo et al., 2001) Saskatchewan (Dosdall et al., 2002), Quebec (Brodeur et al., 2001), and Ontario (Mason et al., 2003b). C. obstrictus is currently controlled through the use of broad-spectrum chemical insecticides (Dosdall et al., 2001; Carcamo et al., 2005). Classical biological control has recently been reconsidered with the aim to reduce the use of chemical cultural control methods. Gibson et al. (2005) recently reviewed the parasitoid - C. obstrictus associations in Canada and determined that data on $M$. morys recoveries after its initial introduction in 1949 were actually based on successive misidentifications of a previously undescribed species, Mesopolobus (Xenocrepis) moryoides Gibson, presumably of North American origin (Gibson et al., 2005). Thus, in contrast to previous beliefs, M. morys, one of the most important parasitoid species regulating C. obstrictus in Europe, is not present in North America.

The importance of systematics in relation to pest management, environment, ecology and quarantine and regulatory activities has been reported by several authors and many studies relate its importance in particular on the relationship of taxonomy to biological control (Knutson \& Murphy, 1988; Huber et al., 2002; Bigler et al., 2005). Indeed, accurate identification of natural enemies is the cornerstone of biological control and essential when 
exotic biological control agents are introduced, especially when morphological variation among species in the genus Mesopolobus associated with Ceutorhynchinae hosts is slight. To decide whether to introduce European parasitoids of $C$. obstrictus into North America, it is crucial to provide clarification of the taxonomic status of these Mesopolobus. Taxonomic clarification has: 1) implications for providing accurate ecological baseline data on parasitoid species associated with Ceutorhynchinae hosts in Europe, the area of origin: and 2) applications towards ensuring safety of classical biological control initiatives.

In this paper we provide: 1) illustrated keys to identify females and males of all Mesopolobus species known from Ceutorhynchinae hosts in Europe; 2) a list of type material examined together with notes on the concordance with specific characters of voucher specimens; 3) a complete list of all voucher specimen examined; and 4) a short diagnosis for females and for males or, if required, a more comprehensive description of the new species or those for which taxonomic status is being changed. Most important characters included in the determination keys and diagnosis are illustrated.

\section{Material and Methods}

Our study is based primarily on surveys in Switzerland, Germany, France, Austria, Hungary, Romania and Ukraine during 2000-2004, which were made to obtain specimens of relevant species of Trichomalus associated with Ceutorhynchus. When stated as "individually reared", the specimens were obtained by dissecting host plants for Ceutorhynchus hosts having a larval ectoparasitoid and then rearing these individually to the adult stage (for detailed rearing methods see Chapter 3). "Mass collected" specimens were obtained by collecting and placing host plants in emergence boxes. Adult parasitoids emerged into glass vials and were collected, killed, air-dried, pinned, labelled and curated for later identification. All voucher specimens stated as collected by F. Muller, B. Klander, M. Grossrieder and M. Cripps were obtained during the 2000-2004 field surveys and are deposited in the Natural History Museum in Bern, Switzerland (NMBE). Additional material, including type specimens of relevant species, was obtained either from the NMBE or from the British Museum of Natural History (BMNH) in London, United Kingdom.

Descriptions are based on observations made using a Leica MZ16 binocular microscope coupled to a Leica CLS $150 \mathrm{x}$ incandescent light source and a light diffuser 
placed over the specimen to reduce the effects of glare. Several images of a specimen were taken through the binocular microscope at different focal planes using a JVC KY-F70BU triple CCD digital camera and processed using the Syncroscopy Auto-Montage ${ }^{\mathrm{TM}}$ software suite. This enabled production of a single, composite, focused image, which allowed us to overcome the problems historically associated with inadequate depth of field for 3dimensional imaging of tiny specimens. Images obtained from the Syncroscopy Automontage $^{\mathrm{TM}}$ software suite were retouched using Adobe Photoshop CS ${ }^{\mathrm{TM}}$ to enhance clarity of the illustrations.

Terms for morphological features and sculpture follow Gibson et al. (1997) and Goulet \& Huber (1993). Terms for colours of various body parts are taken from Graham (1969). Measurements for each species were taken from about 6-10 air dried specimens, depending on availability.

The synonymy of most Mesopolobus species is not quoted here because it often is extensive and is readily accessible electronically in the Universal Chalcidoidea Database (Noyes, 2006); however, for those species where we introduce some nomenclatural change, the complete synonymy is given. 


\section{Identification Keys}

\section{Females}

[Note: Mesopolobus moryoides Gibson also belongs to the group of Mesopolobus species treated here, but has only been recorded from North America (Gibson et al. 2005)].

1 Tegula dark (Fig. 1g). Median area of propodeum smooth, plica indicated in posterior third only (Fig. 1g) .................................................. trasullus (Walker)

- $\quad$ Tegula pale (Fig. 1a - c). Median area of propodeum finely aletaceous, plica more

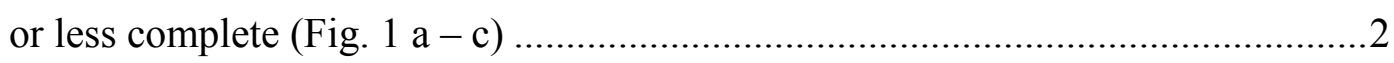

2(1) Tip of hypopygium reaching two thirds along the gaster. Gaster 2.0-2.5 x as long as broad (Fig. 2c). Pedicel plus flagellum about $0.85-0.95 \mathrm{x}$ as long as head breadth (Fig. 3c) ..................................................................... incultus (Walker)

- $\quad$ Tip of hypopygium reaching about half way along the gaster. Gaster 1.35-1.9 x as long as broad (Fig. 2a, b). Pedicel plus flagellumabout $0.7-0.8 \mathrm{x}$ as long as head

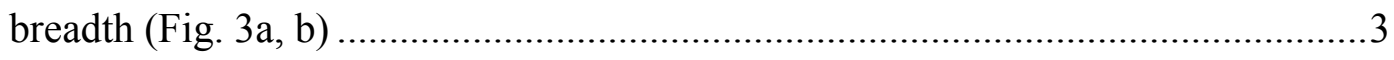

3(2) Speculum extending about to the middle of marginal vein (Fig. 4a, b); basal fold with 2-5 hairs (Fig. 1a, b). Flagellum slightly infuscate (Fig. 3a).

M. gemellus Baur\&Muller sp. nov. Speculum extending about to the distal end of marginal vein (Fig. 4d, e); basal fold with 0-1 hair (Fig. 4d, e). Flagellum slightly paler (Fig. 3b) .

M. morys (Walker) 


\section{Males}

[note: M. trasullus is keyed out according to features given by Askew et al. (1969)]

1 Tegula dark (see Fig. 1g). Median area of propodeum almost smooth, plica indicated in posterior third only ............................................... trasullus (Walker)

- $\quad$ Tegula pale except sometimes apically (Fig. 1d - f). Median area of propodeum finely reticulate, plica more or less complete (Fig. $1 \mathrm{~d}-\mathrm{f}$ ) .................................2

2(1) Marginal vein inflated and only about $4.5 \mathrm{x}$ as long as broad (Fig. 4f). Head more transverse in dorsal view, occiput less concave. Gaster with pale spot medially (Fig. 2f). M. morys (Walker)

- $\quad$ Marginal vein not inflated more than $6 \mathrm{x}$ as long as broad (Fig. 4c, h). Head less transverse in dorsal view, occiput more concave. Gaster without pale spot medially (Fig. 2e, g) ..... 3

3(2) Head in frontal view 1,23-1.31 times as broad as high (Fig. 5a), gena curved M. gemellus Baur\&Muller sp. nov. Head in frontal view 1,14-1.21 times as broad as high (Fig. 1c), gena rather straight. M. incultus (Walker) 


\section{Species treatments}

\section{Mesopolobus gemellus Baur \& Muller sp. nov.}

\section{Type material:}

Holotype male labelled: "ALE 2 coll. 28.VI.2004/61(1) found as larval parasitoid; Alle/ALE2 Jura (Ajoie)/Switzerland GPS lat. N47.436608 long. E07.141965; Ex.: Ceuto. floralis in: C. bursa-pastoris leg. F. Muller/CABI-CH; Holotype $\widehat{\jmath}$ Mesopolobus gemellus sp. n. det. Baur \& Muller 2005".

Paratypes: GERMANY. Ostholstein: Nähtkamp; coll. 14.vi.2000; leg. B. Klander; indiv. reared from larval parasitoids, ex Ceutorhynchus typhae (=C. floralis) in fruits of Capsella bursa pastoris (L.) Medik. (17ð̊; 15ๆ). Schleswig-Holstein: Kiel, Scharnhagen; coll. 1622.vi.2001; leg. B. Klander; indiv. reared from larval parasitoids, ex Ceutorhynchus typhae (=C. floralis) in fruits of Capsella bursa pastoris (L.) Medik. (13 $\overbrace{}^{\lambda} ; 25 \bigcirc)$. SWITZERLAND. Canton Jura: Alle, Les Genavrats, 490 m, N47²6'11.79" E7 8'31.07", 28.vi.2004, leg. F. Muller, ex Ceutorhnchus typhae (Herbst) (Coleoptera: Curculionidae) in fruits of Capsella bursa-pastoris (L.) Medik. (23ðో; 15q). Mass collected material from various sites in: FRANCE. Alsace: Faverois, FAV, N47º31'8.21" E7³'11.94" \& SWITZERLAND. Valais: valley from Martigny to Sion; coll. 9-29. vi. 2004; leg. F. Muller; mass collected adults emerged from pods of Capsella bursa pastoris (L.) Medik. placed in emergence boxes (41§; 31 ) $)$.

\section{Material:}

SWITZERLAND. Valais: Martigny, N46²'36.49" E76'12.82"; coll. 29.VI.2004; leg. F. Muller, ex Ceutorhynchus turbatus Schulze in fruits of Lepidium draba L. (19).

\section{Etymology}

The specific name is formed after the latin noun "gemellus", meaning twin. It refers to the close relationship of this species with M. morys. 

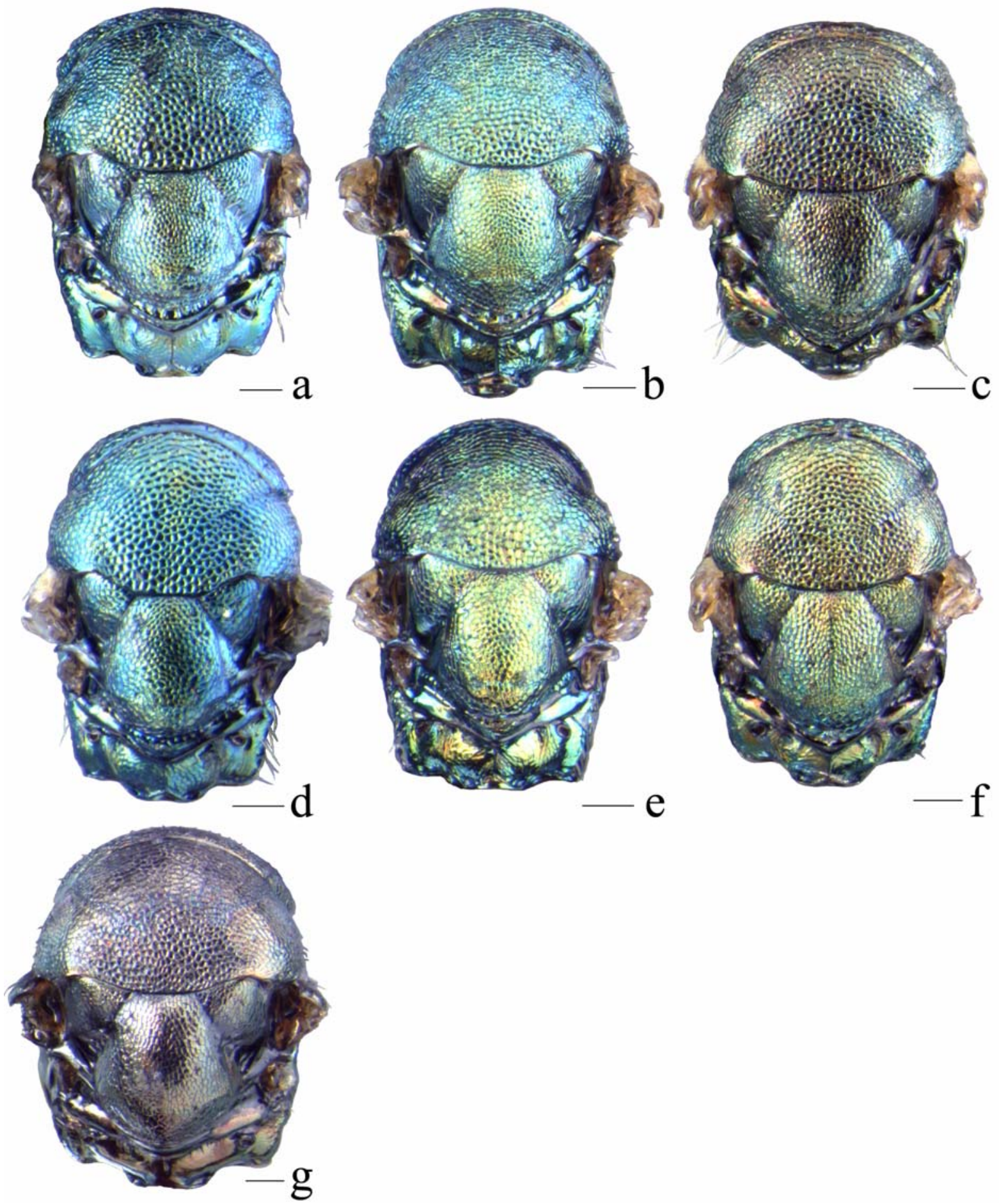

Fig. 1. Mesosoma (dorsal) of (a) $\subsetneq$ Mesopolobus gemellus Baur \& Muller sp. nov.; (b) Mesopolobus morys (Walker, 1848); (c) ๆ Mesopolobus incultus (Walker, 1834); (d) $\lesssim$ M. gemellus; (e) $\precsim$ M. morys; (f) $\widehat{\jmath}$ M. incultus. Scale bars $=100 \mu \mathrm{m}$.

\section{Diagnosis}

Female. Length: 1.5-2 mm (Fig. 6a). Flagellum weakly infuscate (Fig. 3a). Pedicel plus flagellum about $0.75-0.8 \mathrm{x}$ as long as head breadth. Tegulae pale (Fig. 1a). Speculum 
extending to distal end of marginal vein (Fig. 4a, b); basal fold with 2-5 hairs (Fig. 4a, b). Median area of propodeum finely reticulate, plica more or less complete. Gaster 1.3-1.6 (to 1.9) $x$ as long as broad (Fig. 2a); tip of hypopygium reaching about half way along the gaster.

Male. Length: 1.55-1.85 mm (Fig. 6d). Head in frontal view 1.23-1.31 x as broad as high (Fig. 5a), genae curved; in dorsal view about 1.95-2.05 $\mathrm{x}$ as broad as long, occiput rather strongly excaavate. Marginal vein inflated and only about $4.5 \mathrm{x}$ as long as broad (Fig. 4f); tegula pale (Fig. 1d). Median area of propodeum finely reticulate, plica more or less complete. Gaster with indistinct pale spot at base (Fig. 2e).

\section{Description}

Holotype male.

Length: $1.85 \mathrm{~mm}$.

Head bright green with blue tinge in some lights; scape citron yellow; pedicel and flagellum slightly infuscate dorsally, paler below. Mesosoma bright green with bluish tinge. Tegulae yellow. Veins light testaceous. Legs citron yellow except for dark apical tarsal segments. Gaster green with indistinct pale spot at base.

Head in dorsal view $1.97 \mathrm{x}$ as long as broad, $1.27 \mathrm{x}$ as broad as high; occiput rather strongly excavate; POL 2.07 x OOL; malar space $0.63 \mathrm{x}$ eye height; eye $1.23 \mathrm{x}$ as high as broad; face finely reticulate, clypeus reticulate with anterior margin truncate. Antenna with lower edge torulus inserted very slightly above level of lower ocular line; antennal formula 111363; scape not quite extending to ventral margin of anterior ocellus, about $5 \mathrm{x}$ as long as broad and $0.91 \mathrm{x}$ eye height; pedicel in dorsal view $1.8 \mathrm{x}$ as long as broad, slightly longer than anelli plus first funicular segment; combined length of pedicel plus flagellum $0.92 \mathrm{x}$ as long as head breadth; flagellum distinctly clavate; anelli strongly transverse; first funicular slightly transverse and distinctly smaller than second funicular segment; second funicular segment slightly longer than broad, fifth transverse; clava $2.1 \mathrm{x}$ as long as broad, slightly shorter than combined length of 3 apical segments (collapsed in holotype), funicular and claval segments with single row of longitudinal setae.

Mesosoma $1.5 \mathrm{x}$ as long as broad. Pronotal collar differentiated but rounded anteriorly, about one ninth as long as mesoscutum, reticulate with a smooth stripe along postrerior margin; mesoscutum $0.6 \mathrm{x}$ as long as broad, finely reticulate with meshes only very slightly smaller in anterior part; scutellum about as long as broad, $0.92 \mathrm{x}$ as long as mesoscutum, finely reticulate 

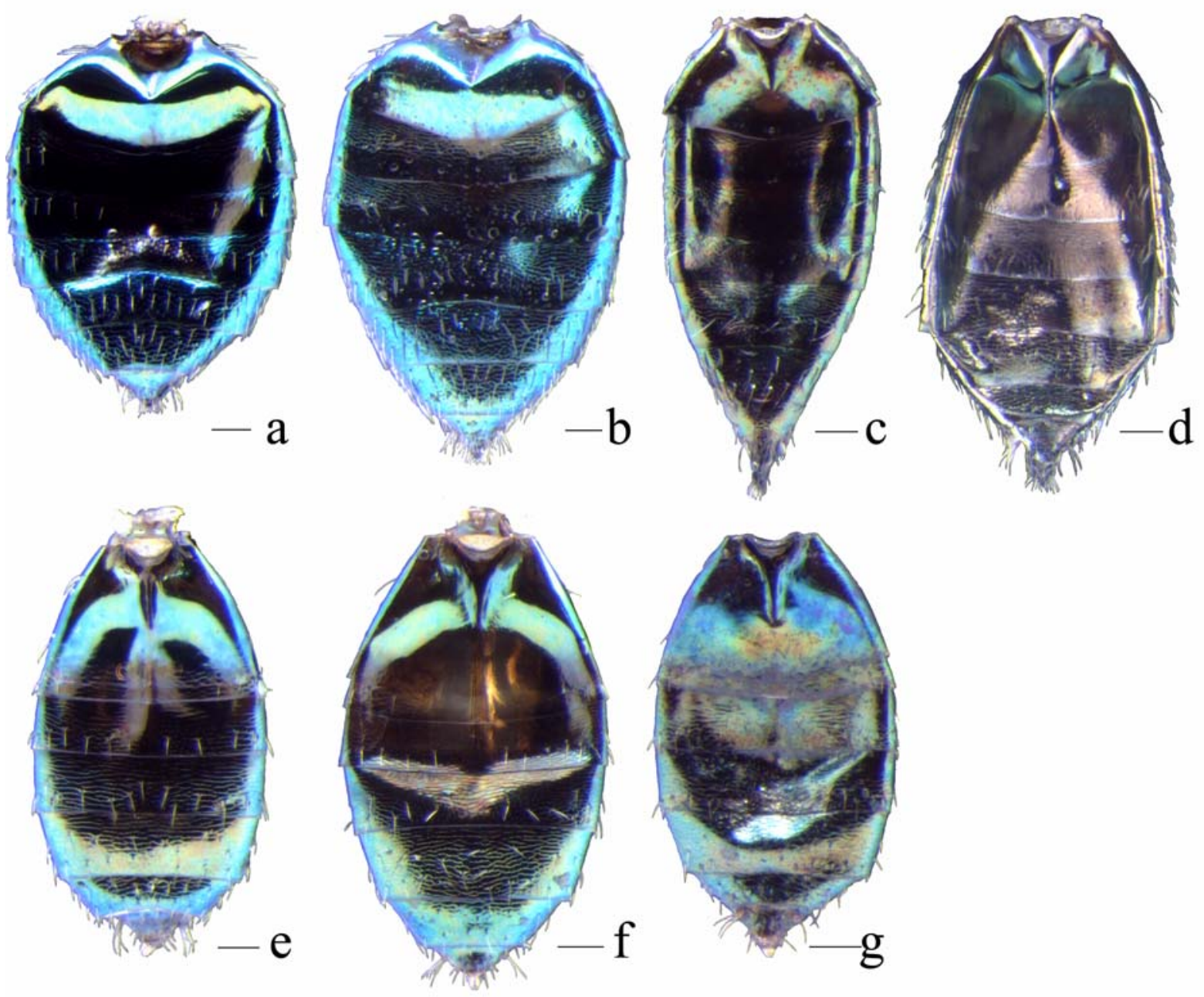

Fig. 2. Metasoma (dorsal) of (a) $\rightarrow$ Mesopolobus gemellus Baur \& Muller sp. nov.; (b) $q$ Mesopolobus morys (Walker, 1848); (c) † Mesopolobus incultus (Walker, 1834); (d) $q$

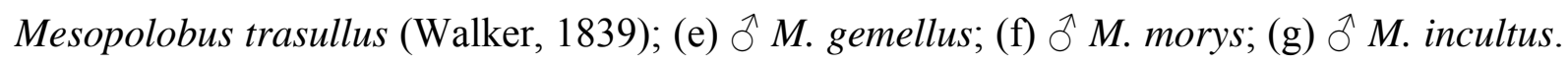
Scale bars $=100 \mu \mathrm{m}$.

with minute meshes along median line and larger meshes on frenum; frenal line indicated laterally; dorsellum alutaceous. Forewing with basal cell with 1-2 setae, basal setal line lacking; costal cell with complete setal line on lower side, upper side bare; speculum extending to middle of marginal vein, open below; marginal vein about $6.3 \mathrm{x}$ as long as broad, not inflatted, $1.33 \mathrm{x}$ as long as stigmal vein and $0.95 \mathrm{x}$ as long as postmarginal vein. Propodeum with superficial but complete plica, median area superficially reticulate, $1.7 \mathrm{x}$ as broad as long, $0.47 \mathrm{x}$ as long as scutellum; median carina distinct, straight; nucha angulate medially; spiracular sulci superficial; right spiracle deformed and tooth like raised in holotype. 
Gaster slightly ovate, $1.78 \mathrm{x}$ as long as broad; tergite 1 smooth, tergites $2-6$ alutaceous; first tergite occupying two fifths of length of gaster.

Female differs from male as follows:

Length $1.8 \mathrm{~mm}$.

Head bright green to blue green; scape testaceous; pedicel and flagellum infuscate. Mesosoma bright blue-green. Tegulae yellow. Veins light testaceous. Legs with coxa concolorous with body, femora broadly fuscous in middle, rest of legs testacoeous. Gaster blue-green.

Head in dorsal view more transverse $2.17 \mathrm{x}$ as long as broad, $1.3 \mathrm{x}$ as broad as high; occiput less strongly excavate; POL $2.25 \mathrm{x}$ OOL; malar space $0.5 \mathrm{x}$ eye height; eye $1.24 \mathrm{x}$ as high as broad; face finely reticulate, clypeus reticulate with anterior margin truncate. Antenna with lower edge torulus inserted distinclty above level of lower ocular line; scape not extending to ventral margin of anterior ocellus, about $4.9 \mathrm{x}$ as long as broad and $0.75 \mathrm{x}$ eye height; pedicel in dorsal view about as long as anelli plus first funicular segment; combined length of pedicel plus flagellum $0.77 \mathrm{x}$ as long as head breadth; first funicular segment about as long as broad and of same size as second.

Gaster ovate pointed, $1.52 \mathrm{x}$ as long as broad; tergite 1 smooth, tergites $2-6$ alutaceous; first tergite occupying one third of length of gaster; hypopygium extending to about middle of the gaster.

\section{Remarks:}

The male of M. gemellus sp. nov. is readily separated from all other Mesopolobus species treated here by the combination of characters given in the key and the diagnosis. However, the female is very close to $M$. morys from which it can only be separated by the slightly reduced fore wing speculum. Because the male sex is much more distinct, it was chosen for the holotype.

The female reared from C. turbatus on Lepidium draba fits the type series quite well, except for a slightly longer gaster. Therefore, it was not included in the type series. 


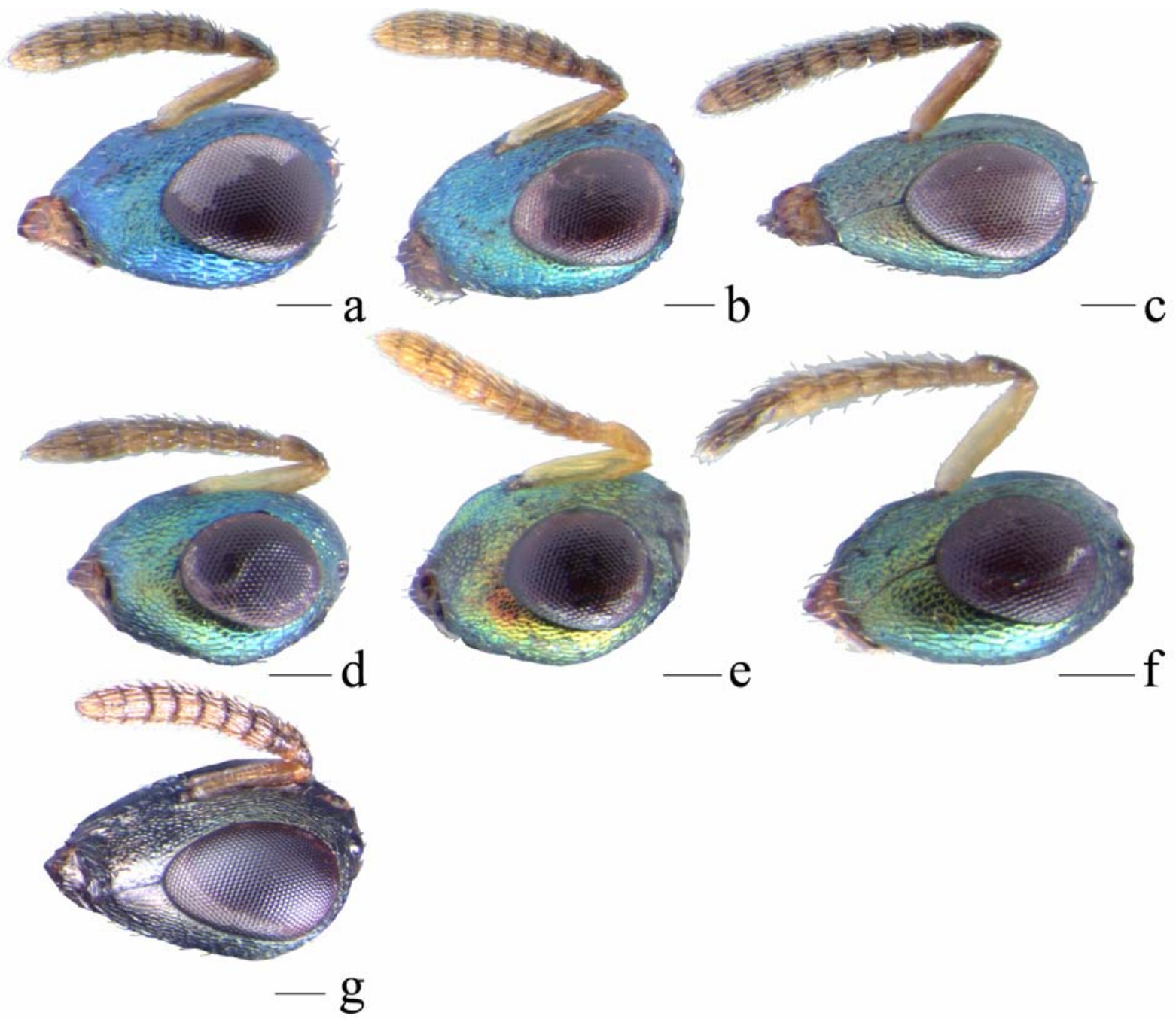

Fig. 3. Head and antennae (front-lateral) of (a) $q$ Mesopolobus gemellus Baur \& Muller sp. nov.; (b) $\subsetneq$ Mesopolobus morys (Walker, 1848); (c) ๆ Mesopolobus incultus (Walker, 1834);

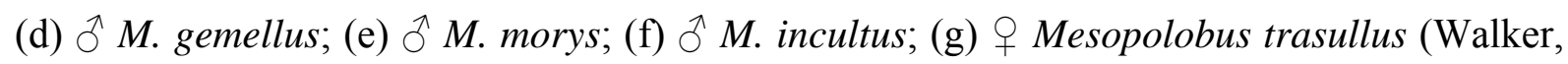
1839). Scale bars $=100 \mu \mathrm{m}$.

\section{Mesopolobus incultus (Walker, 1834)}

\section{Type material:}

Platyterma incultum Walker, 1834, lectotype male in BMNH, designated by Graham (Graham, 1956a) (examined by Gibson).

Amblymerus stupidus Walker, 1834, lectotype female in BMNH, designated by Graham (Graham, 1956a) (examined by Gibson). 
Platyterma femorale Walker, 1834, lectotype female in BMNH, designated by Graham (Graham, 1956a) (examined by Gibson).

Pteromalus ergias Walker, 1839, lectotype male in BMNH, designated by Graham (Graham, 1956a) (examined by Gibson).

Pteromalus leodocus Walker, 1839, lectotype male in BMNH, designated by Graham (Graham, 1956a) (examined by Gibson).

Pteromalus amyntor Walker, 1845, lectotype female in BMNH, designated by Graham (Graham, 1956a) (examined by Gibson).

Pteromalus urgo Walker, 1845, lectotype female in BMNH, designated by Graham (Graham, 1956a) (examined by Gibson).

Pteromalus belesis Walker, 1848, lectotype male in BMNH, designated by Graham (Graham, 1956a) (examined by Gibson).

Pteromalus berecynthos Walker, 1848, lectotype male in BMNH, designated by Graham (Graham, 1956a) (examined by Gibson).

Pteromalus lissos Walker, 1848, lectotype female in Zoological Museum, Lund University, Lund (Sweden), designated by Graham (Graham, 1956a) (not examined).

Eutelus (Amblymerus) crassicornis Thomson, 1878, lectotype female in BMNH, designated by Graham (Graham, 1956a) (examined by Gibson).

\section{Material examined:}

GERMANY. Ostholstein: Nähtkampf; coll. 14.vi.2000; leg. B. Klander; indiv. reared ex C. bursa-pastoris (19). ITALY. Novara: Antronaplana, V. Loranco, W.Rif Andolla, 648.1/105.0, 2300m.; coll. 6.viii.1992; leg. H. Baur (NMBE); collected from sweeping (3q); L. d'Orta, 678.72.4, 310m.; coll. 24.vi.1993; leg. H. Baur (NMBE); collected from sweeping (2q). MOROCCO. Talasoltane, Rif. 1850m.; Coll. 4-11.vii.1961; leg. V. Delucchi (NMBE); collected from sweeping (4ㅇ). SWEDEN. Akarp; coll. 4.vii.1961; leg. H. Von Rosen (NMBE); collected by sweeping (1ठ; 1 1 ). SWITZERLAND. Bern: Bremgarten, 599.4/202.9,550M.; coll. 12.v-18.vii.1992; leg. H. Baur (NMBE); collected from sweeping (69); Diemtigen, SW Griemialp, 602.9/157.1, 1240m.; coll. 9.vi.1992; leg. H. Baur (NMBE); collected from sweeping (1q); Eymatt, 596.7/201.45, 510m.; coll. 20.v.2004; leg. H. Baur (NMBE); collected from sweeping (19); Kandersteg, Undere Allme, 616.025/149.175, 1790m.; coll. 28.viii.1991; leg. H. Baur (NMBE); collected from sweeping (3 9 ); 

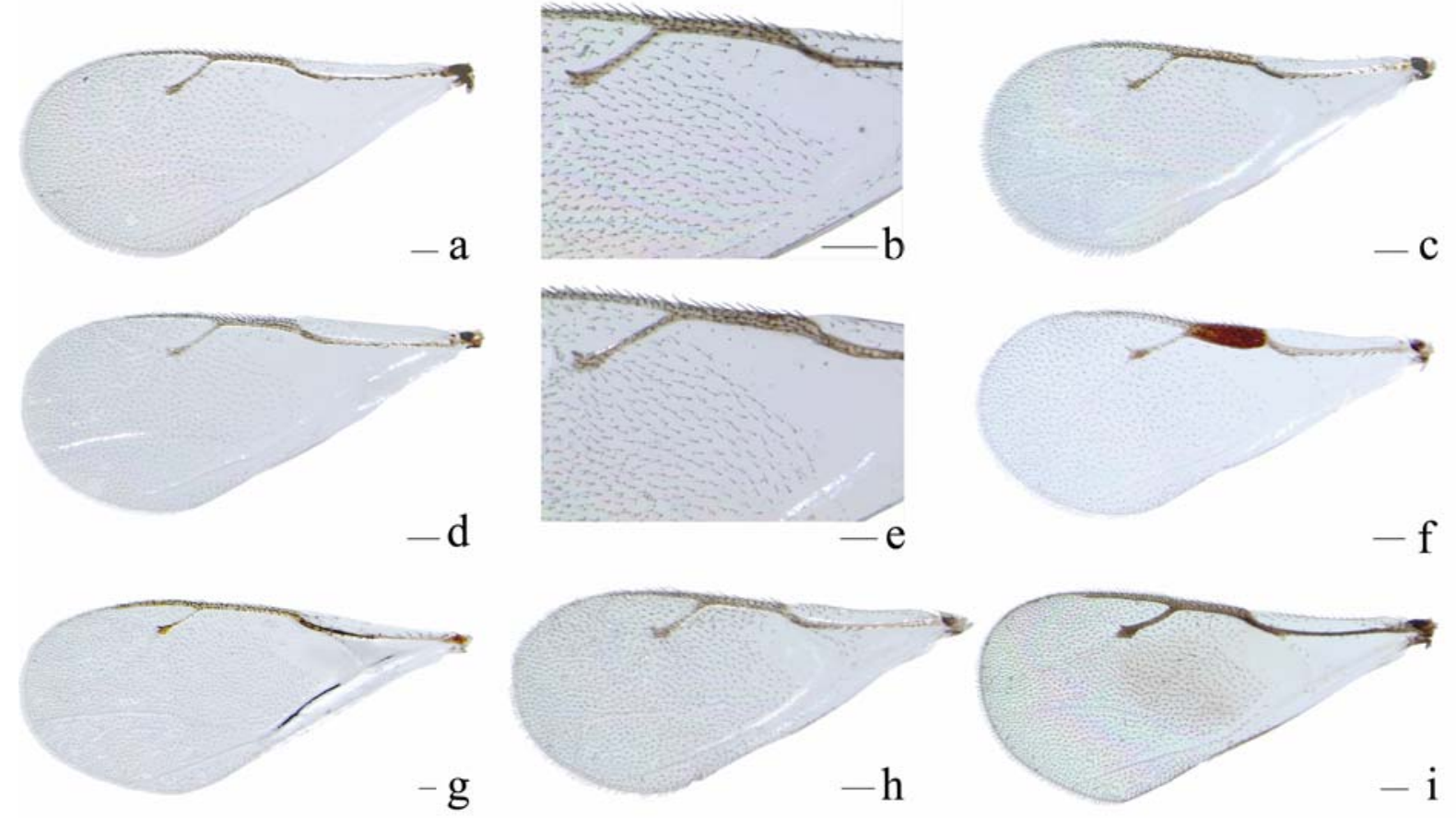

$-\mathrm{f}$

$\mathrm{g}$
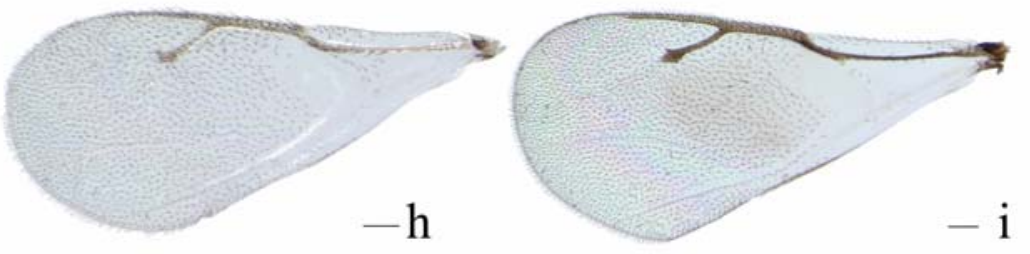

Fig. 4. Forewings of (a) $\subsetneq$ Mesopolobus gemellus Baur \& Muller sp. nov.; (b) $\uparrow$ M. gemellus : detail of speculum; (c) ̊̊ M. gemellus; (d) ๆ Mesopolobus morys (Walker, 1848); (e) $q$ M. morys : detail of speculum; (f) § M. morys; (g) † Mesopolobus incultus (Walker, 1834); (h) $ð$ M. incultus; (i) q Mesopolobus trasullus (Walker, 1839). Scale bars $=100 \mu \mathrm{m}$.

Ruemendingen, 614.9/217.5, 510m.; coll. 26.v.1992; leg. H. Baur (NMBE); collected from sweeping (19); Vauffelin, 591/226, 720m.; coll. 16.vii.1996; leg. H. Baur (NMBE); collected from sweeping (1q); Wohlen b. B., Schürhubel, 588.9/202.35, 520m.; coll.14.v.1992; leg. H. Baur (NMBE); collected from sweeping (3)); Neuchatel: La Brévine, SW Le Maix Rochat, 539.4/205.0, 1050m.; coll. 3-10.viii.1992; leg. C. Vaucher (NMBE); collected from sweeping (1 9 ); Valais: Bitsch, Schwarzes-Flesh, 643.3/133.25, 1620m.; coll. 17.viii.1992; leg. H. Baur (NMBE); collected from sweeping (19); Ferden, Torbu, 623.55/138.7, 2010m.; coll.

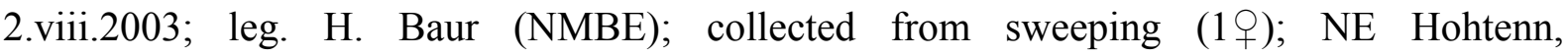
625.65/130.75, 1460m.; coll. 30.vi.1992; leg. H. Baur (NMBE); collected from sweeping

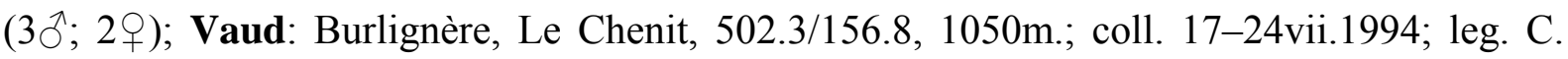
Vaucher (NMBE); collected from sweeping (1); Zurich: Maschwanden, Rüss-Spiez-Ried, 388m.; coll. 21.viii.1989; leg. Rezbanyai-reser (NMBE); collected from sweeping (1); 


\section{Diagnosis:}

Female. Length: 1.5-2.4 mm (Fig. 6c). Flagellum infuscate (Fig. 3c). Pedicel plus flagellum about $0.85-0.95 \mathrm{x}$ as long as head breadth. Tegulae pale (Fig. 1c). Speculum extending to distal end of marginal vein (Fig. 4g); basal fold with 0-2 hairs. Median area of propodeum finely reticulate, plica more or less complete. Gaster 2.0-2.45 x as long as broad (Fig. 2c); tip of hypopygium reaching about two thirds along the gaster.

Male. Length: $1.4-1.8 \mathrm{~mm}$ (Fig. 6f). Head in frontal view 1.13-1.21 x as broad as high (Fig. $3 \mathrm{c}$ ), genae rather straight; in dorsal view about $2.2 \mathrm{x}$ as broad as long, occiput rather strongly concave. Marginal vein not inflated, more than $6 \mathrm{x}$ as long as broad (Fig. 4h); tegula pale (Fig. 1f). Median area of propodeum finely reticulate, plica more or less complete. Gaster without pale spot medially (Fig. 2g).

\section{Remarks:}

The male of $M$. incultus is closest to $M$. gemellus sp. nov., but can be separated by a less transverse head in frontal view (see Fig. 5a, c). From the female it is differentiated by the longer gaster and hypopygium which extends about two third along the gaster.

\section{Mesopolobus morys (Walker, 1848)}

\section{Type material:}

Pteromalus morys Walker, 1848, lectotype male in BMNH, designated by Graham (Graham, 1956a) (not examined).

Encyrtus ceutorhynchi Rondani, 1872, lectotype female in Zoological Museum "La Specola" in Florence (Italy), designated by Boucek (Graham, 1956a) (examined by Baur).

Disema pallipes Förster, 1878, syntype male in Museum für Naturkunde, Berlin

(Germany); synonymized with M. morys by Rosen (1961) (not examined).

Xenocrepis pura Mayr, 1904, holotype male in Naturhistorisches Museum, Vienna (Austria); synonymized with $M$. morys by Graham (1957) (not examined). 

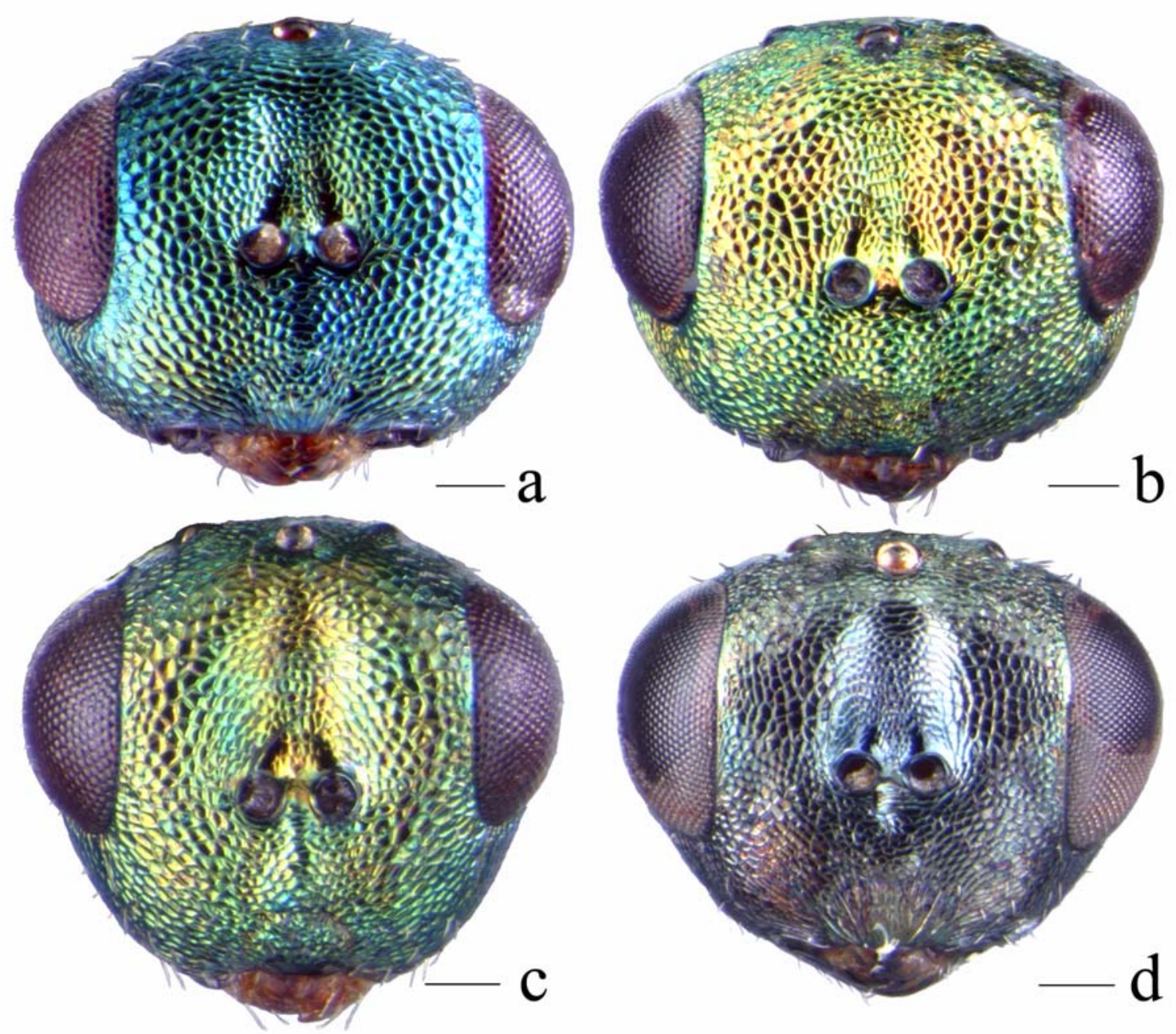

Fig. 5. Head (frontal) of (a) $\widehat{\sigma}$ Mesopolobus gemellus Baur \& Muller sp. nov.; (b) $\widehat{\sigma}$ Mesopolobus morys (Walker, 1848); (c) §̂ Mesopolobus incultus (Walker, 1834); (d) Mesopolobus trasullus (Walker, 1839). Scale bars $=100 \mu \mathrm{m}$.

\section{Material examined:}

FRANCE. Alsace: Boron, BRN3, N47³2'11.34" E70'24.09"; coll. 21.vi.2004; leg. F. Muller, indiv. reared from larval parasitoids, ex. Ceutorhynchus obstrictus in pods of Brassica napus L. (1). Faverois, FAV, N47³1'8.21" E7 3'11.94"; coll. 6.vii.2004; leg. F. Muller; mass. coll, ex. Ceutorhynchus obstrictus in pods of Brassica napus L.(7ðß; 3̊); coll. 28.vi.2004; Leg F. Muller; indiv. reared from larval parasitoids, ex. Ceutorhynchus obstrictus in pods of Brassica napus L.(3今ં; 5 $)$. GERMANY. Schleswig-Holstein: Rastorfer Passau, RP, N54¹6'58.80" E10²0'60.00"; coll. 24-28.vi.2002 \& 1.vii.2002; leg. F. Muller; indiv.

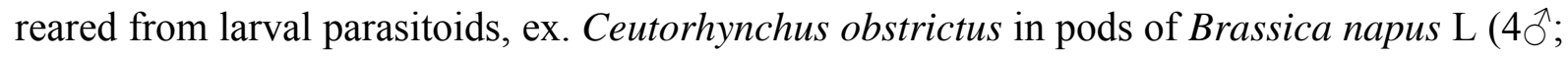
1 ). SWITZERLAND. Jura: Chatillon, La Prîre CHA1, N47²0'3.43" E7²19'56.28"; coll. 9-27.vi.2002 \& 01.vii.2002; leg. F. Muller; indiv. reared from larval parasitoids, ex. 
Ceutorhynchus obstrictus in pods of Brassica napus L.(21ठ; 17@); CHA-LP2; coll. 926.vi.2002, em. 23-27.vi.2003 \& 1-12.vii.2002; Leg. F. Muller; indiv. reared from larval parasitoids, ex. Ceutorhynchus obstrictus in pods of Brassica napus L. (7ð̋; 6ㅇ); coll. 1022.vi.2003, em. 16.vi-27.vii.2003; Leg. F. Muller, indiv. reared from larval parasitoids, ex. Ceutorhynchus obstrictus in pods of Brassica napus L.(15ð⿱ ; 32 +); CHA-LP3; coll. 1025.vi.2002, em. 25-27.vi.2003 \& 1-20.vii.2002; Leg. F. Muller, indiv. reared from larval parasitoids, ex. Ceutorhynchus obstrictus in pods of Brassica napus L $(9 \hat{\jmath} ; 14+$ ); Coeuve, COE1, N47²7'55.00" E76'40.01"; coll. 21.vi.2004; leg. F. Muller, indiv. reared from Larval parasitoids, ex. Ceutorhynchus obstrictus in pods of Brassica napus L (1ठ); Courrendlin, COUR1, N47²0'47.55" E7²17'36.21"; coll. 15.vi.2004; leg. F. Muller; indiv. reared from larval parasitoids, ex. Ceutorhynchus obstrictus in pods of Brassica napus L. (1ડ̄; 1q); Courroux, CRX11, N47²2'1.64" E7²2'3.90"; coll. 21.vi.2004; leg. F. Muller; indiv. reared from larval parasitoids, ex. Ceutorhynchus obstrictus in pods of Brassica napus L $(2 \hat{O} ; 1$ q); Delémont, Le Chavelier DEL-DOM; coll. 10-20.vi.2003, em. 21.vi-11.vii.2003; Leg. F. Muller; indiv. reared from larval parasitoids, ex. Ceutorhynchus obstrictus in pods of

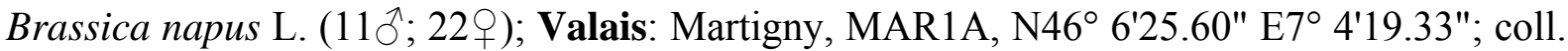
29.vi.2004 \& 5.vii.2004; Leg. F. Muller; indiv. reared from larval parasitoids, ex Ceutorhynchus turbatus Schultze in pods of Lepidium draba L. $(9 \overbrace{}^{\lambda} ; 4$ ). MAR2, N46 ${ }^{\circ}$ 6'47.04" E76'54.24"; coll. 15.vi-5.vii.2004; Leg. F. Muller; indiv. reared from larval parasitoids, ex Ceutorhynchus turbatus Schultze in pods of Lepidium draba L. (7ठ̊; 11 9 ). Ecône-Riddes, VS-Eco, N46¹0'28.87" E7²12'54.19"; coll. 17.vi.2004, em. 3.vii.2003; Leg. F. Muller; indiv. reared from larval parasitoids, ex Ceutorhynchus turbatus Schultze in pods of Lepidium draba L. (2ᄋ); Saxon, VS-Sax; coll. 17\&22.vi.2004, em. 27.vi-11.vii.2003; Leg. F. Muller; indiv. reared from larval parasitoids, ex Ceutorhynchus turbatus Schultze in pods

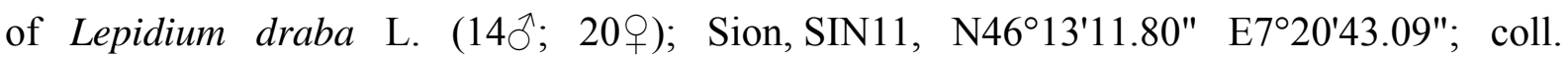
29.vi.2004 \& 5.vii.2004; Leg. F. Muller; indiv. reared from larval parasitoids, ex Ceutorhynchus turbatus Schultze in pods of Lepidium draba L. (14ðં; 7 ); Sion VS-SW1; coll. 17\&22.vi.2004, em. 3-11.vii.2003; Leg. F. Muller; indiv. reared from larval parasitoids, ex Ceutorhynchus turbatus Schultze in pods of Lepidium draba L. (2今; 2 \%). HUNGARY. Csongrad: Lep-HU36, N46²4'50.80" E200'3.24"; coll. 24.vi-11.vii.2004; Leg. F. Muller; indiv. reared from larval parasitoids, ex Ceutorhynchus turbatus Schultze in pods of Lepidium

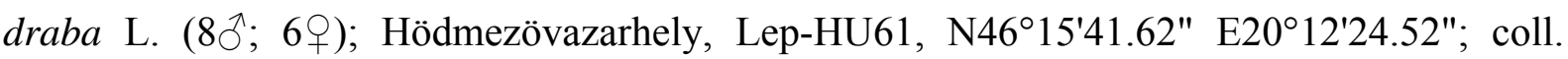
22.vi-11.vii.2004; leg. F. Muller; indiv. reared from larval parasitoids, ex Ceutorhynchus turbatus Schultze in pods of Lepidium draba L. (4તิ; 4ㅇ). Pest: Apaj, Lep-HU65, 
N47²12'9.12" E19¹3'50.22"; coll. 24.vi.2004 \& 11.vii.2004; leg. F. Muller; indiv. reared from larval parasitoids, ex Ceutorhynchus turbatus Schultze in pods of Lepidium draba L.

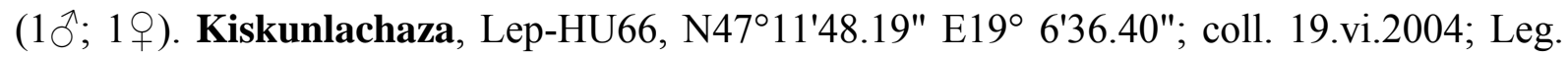
F. Muller; indiv. reared from larval parasitoids, ex Ceutorhynchus turbatus Schultze in pods of Lepidium draba L. (1 $\overbrace{}^{\Uparrow})$. Budapest, Lep-HU7B, N47²1230.24" E19¹3'6.06"; coll. 30.vi.2004 \& 11.vii.2004; leg. F. Muller; indiv. reared from larval parasitoids, ex Ceutorhynchus turbatus Schultze in pods of Lepidium draba L. (2へ).

\section{Diagnosis:}

Female. Length: 1.6-2.5 mm (Fig. 6b). Flagellum weakly infuscate (Fig. 3b). Pedicel plus flagellum about $0.7-0.8 \mathrm{x}$ as long as head breadth. Tegulae pale (Fig. 1b). Speculum extending to distal end of marginal vein (Fig. 4f); basal fold with 0-1 hairs. Median area of propodeum finely reticulate, plica more or less complete. Gaster 1.4-1.8 x as long as broad (Fig. 2b); tip of hypopygium reaching about half way along the gaster.

Male. Length: 1.4-2.1 mm (Fig. 6e). Head in frontal view $1.22-1.33 \mathrm{x}$ as broad as high, genae curved; in dorsal view about $2 \mathrm{x}$ as broad as long, occiput weakly concave. Marginal vein inflated and only about $4.5 \mathrm{x}$ as long as broad (Fig. 4f); tegula pale (Fig. 1e). Median area of propodeum finely reticulate, plica more or less complete. Gaster without pale spot medially (Fig. 2f).

\section{Remarks:}

The male of $M$. morys is readily recognized by the inflated marginal vein (Fig. 4f), which is unique among species of Mesopolobus. It was therefore not necessary to re-examine the male types of the synonyms cited above. However, the female is very close to M. gemellus sp. nov., from which it is separated only by a slightly larger fore wing speculum (Fig. 4e). 


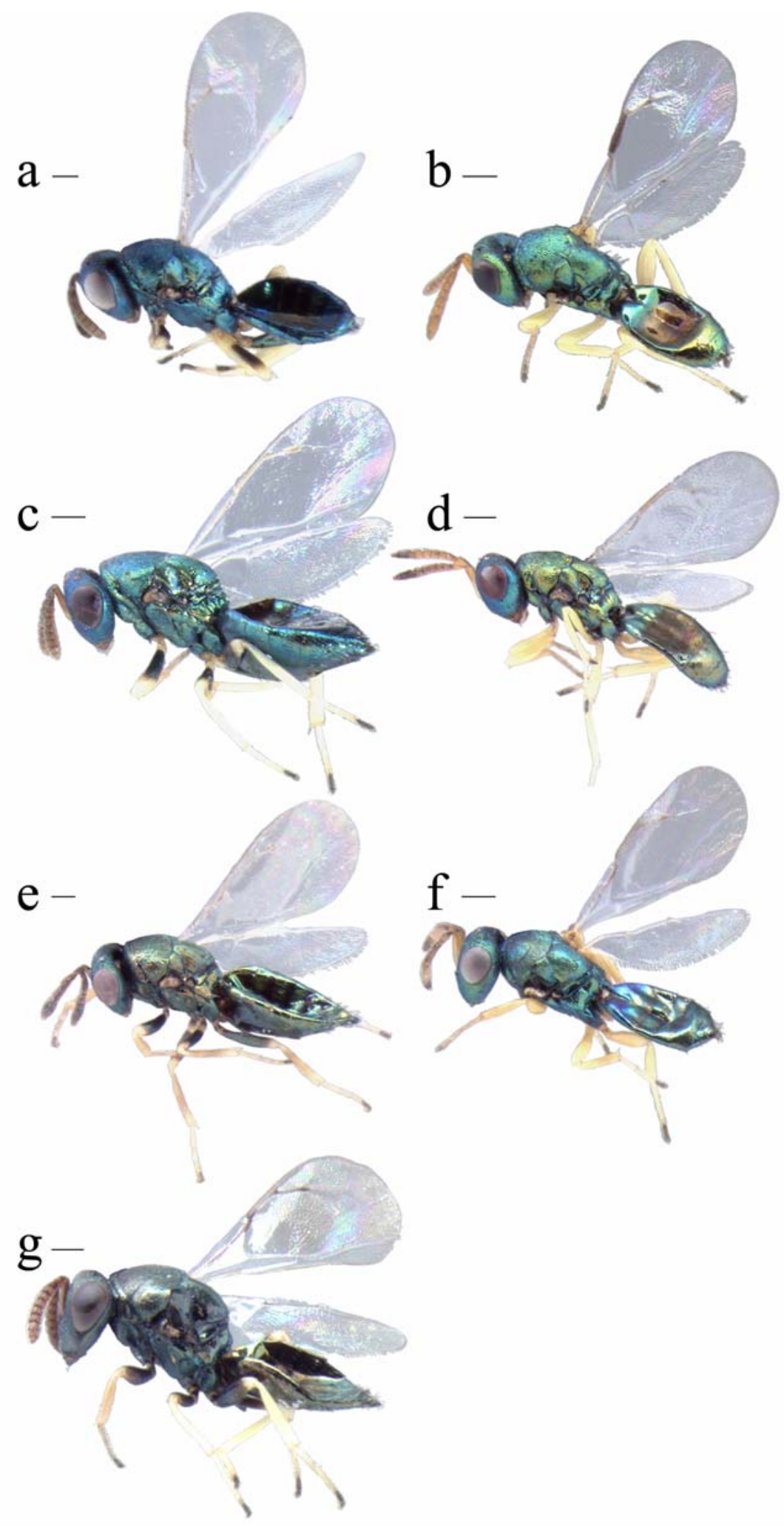

Fig. 6. Habitus of (a) $\subsetneq$ Mesopolobus gemellus Baur \& Muller sp. nov.; (b) $\subsetneq$ Mesopolobus morys (Walker, 1848); (c) ๆ Mesopolobus incultus (Walker, 1834); (d) § M. gemellus; (e) $\widehat{\jmath}$ M. morys; (f) § M. incultus; (g) ๆ Mesopolobus trasullus (Walker, 1839). Scale bars $=200$ $\mu \mathrm{m}$. 


\section{Mesopolobus trasullus (Walker, 1839)}

\section{Type material:}

Ormocerus trasullus Walker, 1839, lectotype female in BMNH, designated by Graham (examined by Gibson).

Mesopolobus roseni Graham, 1984, holotype female in BMNH (examined by Gibson).

\section{Material examined:}

CZECH REPUBLIC. Bohemia: Praha-Butovice, Prokopskè Udoli, lat. N5002.609”' long. E014²1.348', 100m; coll. 7.vi.2004; leg. H. Baur (NMBE); collected by sweeping (1q). SWITZERLAND. Basel: Bottmingen; coll. 22.vii.1935; leg. W. Wittmer (NMBE) (1 + ).

\section{Diagnosis:}

Female. Length: 2.1-2.3 mm (Fig. 6g). Flagellum infuscate dorsally, slightly paler on lower side (Fig. 3g). Pedicel plus flagellum about $0.77 \mathrm{x}$ as long as head breadth. Tegulae dark (Fig. $1 \mathrm{~g})$. Speculum extending about to the middle of the marginal vein (Fig. 4d); basal fold with 2-5 hairs. Median area of propodeum smooth, plica indicated in posterior third only. Gaster $1.7 \mathrm{x}$ as long as broad (Fig. 2d); tip of hypopygium reaching about half way along the gaster.

\section{Remarks:}

Gibson \& Baur (2005) pointed out that M. trasullus was erroneously synonymised under $M$. incultus by Graham (1956b) and recognized it as a senior synonym of Mesopolobus roseni Graham, 1984. Because males of this species were not available for study, the characters given in the key were taken from Askew et al. (2001).

\section{Discussion}

All Mesopolobus species previously known as parasitoids of Ceutorhynchinae hosts in Europe were described and included in the key. Features are provided to differentiate Mesopolobus morys, M. incultus and M. trasullus from Mesopolobus gemellus sp. nov. Results of this study will have direct implications on allowing us to provide ecological 
baseline data for correctly identify parasitoid-Ceutorhynchinae host associations, which is essential for a renewed classical biological initiate against $C$. obstrictus in Canada. In this context, M. morys with its main host C. obstrictus, was thought to occur on C. typhae (=floralis) in Europe (Klander, 2001). We show here that these records were based on misidentifications of $M$. gemellus, undescribed at the time of those studies. However, $M$. morys is for the first time accurately associated with the seed weevil C. turbatus, a potential agent for classical biological control of hoary cress, Lepidium draba in North America.

Concern regarding potential non-target effects of invertebrate biological control agents of arthropods has risen over the last decade and an increasing number of studies have since dealt with this topic (Babendreier et al., 2005). The taxonomic clarification reported in this paper provides a sound basis for accurate documentation of Ceutorhynchus spp. - Mesopolobus spp. host-parasitoid associations. This information is of significant interest to the scientific community involved in the classical biological control of C. obstrictus in North America (Kuhlmann et al., 2006a) because biological control practioners now have to assess potential non-target impacts of invertebrate biological control agents to justify release.

It should be noted that in general the understanding of the population dynamics of Ceutorhynchinae species of economic importance is still hampered by the insufficient knowledge of natural enemy complexes that may play an important role in regulating these herbivorous insects (Vidal, 2003). Clarification of the taxonomy of Mesopolobus species presented here provides a sound basis for understanding these dynamics, leading towards the safe use of Mesopolobus species against Ceutorhynchinae pest species. 


\section{Acknowledgments}

We acknowledge Emmanuel Cuenot (France), MSc Virginia Larraz (Spain), MSc Leonore Lovis (Switzerland), Gabor Nagy (Hungary), Fezekas Janos (Hungary), Alicia Leroux (Canada), MSc Tara Gariepy (Canada), Kim Riley (Canada), Lars Andreassen (Canada), MSc Leyla Valdivia Buitriago (Peru), MSc Rike Stelkens (Germany) and MSc Stephen Maggins (Ireland) for their precious help as part of the CABI Agricultural Pest Research dissection team. Maren Belde (Technischen Universität Munich, Germany) and MSc Beate Klander (Christian Albrechst Universtity, Kiel, Germany) for finding collection sites of Canada thistle in Germany. Dr. Scheibelreiter (Wien, Austria) assisted with collections of scentless chamomile in Austria in 2003. We appreciated the fruitful discussions with Dr. André Gassmann, Dr. Hariet Hinz, Dr. Stefan Toepfer and Dr. Esther Gerber (all CABI, Delémont) and acknowledge them as well for information exchanged on collection sites of scentless chamomile, hoary cress, Canada thistle, garlic mustard and other Ceutorhynchinae host plants in various European countries. This work was funded by Agriculture and Agri-Food Canada, and AAFC's Pest Management Research Centre Project PRR03-370 and the Alberta Agricultural Research Institute Reseach Institute. Technical support was provided by the Natural History Museum at Bern, Switzerland 


\section{References}

Askew, R. R., J. Blasco-Zumeta \& J. Pujade-Villar (2001). Chalcidoidea and Mymarommatoidea (Hymenoptera) of a Juniperus thurifera L. forest of Los Monegros region, Zaragosa. Monografias Sociedad Entomológica Aragonesa 4, 17pp.

Babendreier, D., F. Bigler \& U. Kuhlmann (2005). Methods used to assess non-target effects of invertebrate biological control agents of arthropod pests. BioControl 50 (6), 821870.

Bigler, F., J. S. Baleb, M. J. W. Cock, H. Dreyer, R. Greatrex, U. Kuhlmann, A. J. M. Loomans \& J. C. Van Lenteren (2005). Guidelines on information requirements for import and release of invertebrate biological control agents in European countries. $C A B$ Reviews: Perspectives in Agriculture, Veterinary Science, Nutrition and Natural Resources 1 (001), 1-10.

Brodeur, J., L. Leclerc, M. Fournier \& M. Roy (2001). The cabbage seedpod weevil, Ceutorhynchus obstrictus (Coleoptera: Curculionidae): a new pest of canola in northeastern North America. The Canadian Entomologist 133 (5), 709-711.

Carcamo, H. A., L. M. Dosdall, M. Dolinski, O. Olfert \& J. R. Byers (2001). The cabbage seedpod weevil, Ceutorhynchus obstrictus (Coleoptera: Curculionidae) - a review. Journal of the Entomological Society of British Columbia 98, 201-210.

Carcamo, H. A., L. M. Dosdall, D. Johnson \& O. Olfert (2005). Evaluation of foliar and seed treatments for control of the cabbage seedpod weevil (Coleoptera: Curculionidae) in canola. The Canadian Entomologist 137, 476-487.

Colonnelli, E. (2004). Catalogue of Ceutorhynchinae of the world, with key to genera. Argania edito, Balmes, Barcelona. 124 pp.

De Clerck-Floate, R. A. \& M. Schwarzlaender (2002). Cynoglossum officinale (L.), Houndstongue (Boraginaceae). In: P. G. Mason and J. T. Huber (Eds.) Biological Control Programmes in Canada 1981-2000. CABI Publishing, Wallingford, UK. 337343.

Dieckmann, L. (1972). Beiträge zur Insektenfauna der DDR: Coleoptera - Curculionidae: Ceutorhynchinae. Beitrage zur Entomologie 22 (1/2), 3-128.

Dosdall, L. M., D. Moisey, H. A. Carcamo \& R. Dunn (2001). Cabbage seedpod weevil fact sheet. Alberta Agriculture, Food and Rural Development Agdex 622-21, 1-4. 
Dosdall, L. M., R. M. Weiss, O. Olfert \& H. A. Carcamo (2002). Temporal and geographical distribution patterns of the cabbage seedpod weevil (Coleoptera: Curculionidae) in canola. The Canadian Entomologist 134 (3), 403-418.

Gibson, G. A. P. \& H. Baur (2005). Mesopolobus trasullus (Walker, 1839), a valid species and senior synonym of Mesopolobus roseni Graham, 1984 (Hymenoptera: Chalcidoidea: Pteromalidae). Entomologist's Gazette 56, 129-132.

Gibson, G. A. P., H. Baur, B. Ulmer, L. Dosdall \& F. J. Muller (2005). On the misidentification of the chalcid (Hymenoptera: Chalcidoidea) parasitoids of the cabbage seedpod weevil (Coleoptera: Curculionidae) in North America. The Canadian Entomologist 137, 381-403.

Gibson, G. A. P., J. T. Huber \& J. R. Woolley (1997). Annotated Keys to the Genera of Nearctic Chalcidoidea (Hymenoptera). NRC Research Press, Ottawa. 772 pp.

Goulet, H. \& J. T. Huber (1993). Hymenoptera of the world: An identification guide to families. Research Branch Agriculture Canada, Ottawa, Ontario. 660 pp.

Graham, M. W. R. (1956a). A revision of the Walker types of Pteromalidae (Hym., Chalcidoidea). Part 2 (including descriptions of new genera and species). Entomologist’s Monthly Magazine 92, 246-263.

Graham, M. W. R. (1956b). A revision of the Walker types of Pteromalidae (Hym., Chalcidoidea). Part 3 (including descriptions of new genera and species). Entomologist’s Monthly Magazine 93, 217-236.

Graham, M. W. R. (1969). The Pteromalidae of North-Western Europe (Hymenoptera: Chalcidoidea). Bulletin of the British Museum (Natural History) Entomology (Suppl.16), 908pp.

Howarth, F. G. (1991). Environmental impacts of classical biological control. Annual Review of Entomology 36, 485-509.

Huber, J. T., S. Darbyshire, J. Bisset \& R. G. Footit (2002). Taxonomy and biological control. In: P. G. Mason and J. T. Huber (Eds.) Biological control programmes in Canada, 1981-2000. CABI Publishing. 14-22.

Julien, M. H. \& M. W. Griffiths (1998). Biological control of weeds - A world Catalogue of Agents and their target weeds. CABI Publishing, Wallingford, Oxon, UK. 223 pp.

Klander, B. (2001). Die Rüsselkäfer der Unterfamilie Ceutorhynchinae und deren parasitoide auf Winterraps und begleitenden Unkräutern in Schleswig-Holstein. MSc Thesis. Zoologisches Institut der Christian-Albrechts-Universität zu Kiel, Department of Ecology, Kiel, Germany. pp. 
Knutson, L. \& W. L. Murphy (1988). Systematics: relevance, resources, services, and management. a bibliography. Association of Systematics Collections (Suppl. 1), Washington, DC.

Kuhlmann, U., L. M. Dosdall \& P. G. Mason (2002). Ceutorhynchus obstrictus (Marsham), cabbage seedpod weevil (Coleoptera: Curculionidae). In: P. G. Mason and J. T. Huber (Eds.) Biological Control Programmes in Canada, 1981-2000. CABI Publishing, Wallingford, Oxon, U.K. 52-58.

Kuhlmann, U., P. G. Mason, H. L. Hinz, B. Blossey, R. A. De Clerck-Floate, L. Dosdall, J. P. McCaffrey, M. Schwarzlaender, O. Olfert, J. Brodeur, A. S. McClay \& R. N. Wiedenmann (2006a). Avoiding conflicts between insect and weed biological control: selection of non-target species for test list to assess host specificity of cabbage seedpod weevil parasitoids. Journal of Applied Entomology 130 (3), 129-141.

Kuhlmann, U., U. Schaffner \& P. G. Mason (2006b). Selection of non-target species for host specificity testing. In: F. Bigler, D. Babendreier and U. Kuhlmann (Eds.) Environmental impact of invertebrates for biological control of Arthropods: Methods and risk assessment. CABI Publishing., Wallingford, Oxon, UK. 15-37.

Louda, S. M., et al. (2003). Nontarget effects: the Achilles' heel of biological control? Retrospective analysis to reduce risk associated with biocontrol introductions. Annual Review of Entomology 48, 365-396.

Mason, P. G., T. Baute, O. Olfert \& M. Roy (2003). Cabbage Seedpod Weevil, Ceutorhynchus obstrictus (Marsham) (Coleoptera:Curculionidae) in Ontario and Quebec. Journal of the Entomological Society of Ontario 134, 107-113.

Mason, P. G. \& J. T. Huber (Eds.) (2002). Biological control programmes in Canada, 19812000. CABI Publishing, Wallingford, UK. 583 pp.

McClay, A. S., R. S. Bourchier, P. A. Butts \& D. P. Peschken (2002a). Cirsium arvense (L.) Scopoli, Canada thistle (Asteraceae). In: P. G. Mason and J. T. Huber (Eds.) Biological Control Programmes in Canada, 1981-2000. CABI Publishing, Wallingford, Oxon, UK. 318-330.

McClay, A. S., H. L. Hinz, R. A. De Clerck-Floate \& D. P. Peschken (2002b). Matricaria perforata Mérat, Scentless Chamomille (Asteraceae). In: P. G. Mason and J. T. Huber (Eds.) Biological Control Programmes in Canada, 1981-2000. CABI Publishing, Wallingford, Oxon, UK. 395-402.

McLeod, J. H. (1953). Notes on the cabbage ceedpod weevil, Ceutorhynchus assimilis (Payk.) (Coleoptera : Curculionidae), and its parasites. Entomological Society of British Columbia, Proc. 49, 11-18.

McLeod, J. H. (1962). Part 1 - Biological control of pests of crops, fruit trees, ornamentals, and weeds in Canada up to 1959. In: A review of the biological control attempts 
against insects and weeds in Canada. Commonwealth Agricultural Bureaux, Farnham, Bucks, UK. 216.

Murchie, A. K. \& I. H. Williams (1998). A bibliography of the parasitoids of the cabbage seed weevil (Ceutorhynchus assimilis Payk.). IOBC wprs Bulletin 21 (5), 163-169.

Noyes, J. S. (2006). Universal Chalcidoidea Database. www.nhm.ac.uk/entomology/chalcidoids/index.html. last accessed 20-April-2006.

Simberloff, D. (2005). The politics of assessing risk for biological invasions: the USA as a case study. Trends in Ecology and Evolution 20 (5), 216-222.

Simberloff, D. \& P. Stiling (1996). How risky is biological control? Ecology 77, 1965-1974.

Stiling, P. (2004). Biological control not on target. Biological invasions 6, 151-159.

Stiling, P. \& D. Simberloff (2000). The frequency and strength of nontarget effects of invertebrate biological control agents of plant pests and weeds. In: P. A. Follet and J. J. Duan (Eds.) Nontarget Effects of Biological Control. Kluwer Academic Publishers, Norwell/USA. 31-43.

Thomas, M. B. \& A. J. Willis (1998). Biocontrol - risky but necessary? Trends in Ecology and Evolution 13 (8), 325-329.

Van Driesche, R. G. \& R. Reardon (2004). Assessing host ranges for parasitoids and predators used for classical biological control: A guide to best practice. Forest Health Technology Enterprise Team, USDA-Forest Service, Morgantown, WV, USA. 243 pp.

Vidal, S. (2003). Identification of Hymenopterous parasitoids associated with oilseed rape pests. In: D. V. Alford (Ed.) Biocontrol of Oilseed Rape Pests. Blackwell Science, Oxford. 161-179.

Williams, I. H. (2003). Parasitoids of Cabbage Seed Weevil. In: D. V. Alford (Ed.) Biocontrol of Oilseed Rape Pests. Blackwell Science, Oxford. 97-112.

Wright, M. G., M. P. Hoffmann, T. P. Kuhar, J. Gardner \& S. A. Pitcher (2005). Evaluating risks of biological control introductions: A probabilistic risk-assessment approach Biological Control 35 (3), 338-347. 


\title{
European Ectoparasitoid Assemblages of Two Classical Weed
}

\author{
Biological Control Agents Released in North America:
}

\section{Ensuring the Safety of Biological Control Agents for}

\section{Cabbage Seedpod Weevil}

\author{
Franck J. Muller ${ }^{1}$, Peter G. Mason ${ }^{2}$, Lloyd M. Dosdall ${ }^{3}$ \& Ulrich Kuhlmann ${ }^{1}$ \\ 1- CABI Switzerland Centre, Rue des Grillons 1, 2800 Delémont, Switzerland \\ 2- Agriculture and Agri-Food Canada, Research Centre, 960 Carling Avenue, Ottawa, Canada \\ 3- Department of Agricultural, Food and Nutritional Sciences, University of Alberta, 4-10 Agriculture / \\ Forestry Centre, Edmonton, Canada
}

\begin{abstract}
Among the species of the curculionid subfamily Ceutorhynchinae, two stem miners Hadroplontus litura (Fabricius) and Microplontus edentulus (Schultze), have been released and are established as biological control agents for two weeds of economic importance, Canada thistle, Cirsium arvense (L.) Scopoli and scentless chamomile, Tripleurospermum perforatum (Mérat) Laínz (=Matricaria perforata Mérat), respectively. Canada thistle and scentless chamomile occur in the same regions and same kind of habitats as the cabbage seedpod weevil, Ceutorhynchus obstrictus (Marsham) [=C. assimilis (Paykull); see Colonnelli (2004)], a major pest of canola (Brassica napus L.) in North America. Several chalcid parasitoid species such as Mesopolobus morys Walker, Trichomalus perfectus Walker and Stenomalina gracilis Walker are being evaluated as candidate classical or inundative biological control agents. Those Ceutorhynchinae released to control weeds in cultivated crops will be at great risk of potential attack if agents released for biological control of $C$. obstrictus are not specific to that species. A three-year field survey was carried out to collect $H$. litura and M. edentulus and their ectoparasitoids in France, Germany, Austria and Hungary. The ectoparasitoids were reared to adults and identified with the aim of verifying whether or not the candidate ectoparasitoids occur in the assemblages associated with these
\end{abstract}


two non-target species. Despite phenological overlap of $M$. edentulus and H. litura with $C$. obstrictus, and sympatric distributions in Europe, $M$. morys did not parasitize $M$. edentulus or $H$. litura. Furthermore, we found no evidence that $T$. perfectus attacks these species. In contrast, S. gracilis parasitized M. edentulus at several sites surveyed during two years, in Austria and Hungary.

\section{Introduction}

Classical biological control, i.e. the introduction and establishment of exotic insects, mites, or pathogens to give permanent control, is the predominant strategy used for biological control of weeds (McFadyen, 1998). Its application is highly recommended to control established non-indigenous invasive weed populations (Wittenberg \& Cock, 2001). Review of classical biological control agents released in Canada, United States, Australia and New Zealand against weeds indicated that more than $50 \%$ of these 85 agents belong to the Curculionidae, Chrysomelidae (Coleoptera), and Tephritidae (Diptera) (Gassmann, 1995; Mason \& Huber, 2002; Coombs, 2004). A total of 13 species of the curculionid subfamily Ceutorhynchinae have been released in Canada for biological control of 10 weeds. Among these are Hadroplotus litura (Fabricius) (McClay et al., 2002a) and Microplontus edentulus (Schultze) (McClay et al., 2002b).

Microplontus edentulus, a stem mining weevil, was released to control scentless chamomile, Tripleurospermum perforatum (Mérat) Laínz (=Matricaria perforata Mérat) [Asteraceae], a weed of cultivated land (Hinz \& McClay, 2000). Scentless chamomile forms dense, semi-permanent stands in periodically disturbed sites such as slough margins, field depressions or roadsides, from which seeds disperse into adjacent fields. Biological control targets these populations in uncultivated areas because chemical and cultural control methods are impractical in these habitats (Hinz \& McClay, 2000). Adult M. edentulus overwinter and in early summer lay eggs into the upper parts of scentless chamomile stems. Larval feeding reduces both seed output and biomass of scentless chamomile (Bacher, 1993). Hinz et al. (1996) confirmed that M. edentulus has a narrow host range in its area of origin in southeastern Europe. According to Julien and Griffiths (1998), M. edentulus is established only in Alberta. 
Hadroplontus litura (Fabricius), a stem- and root-mining weevil, was released to control Canada thistle, Cirsium arvense (L.) Scopoli [Asteraceae] in Canada (McClay et al., 2002a). Canada thistle is one of the most widespread and competitive European weeds in United States and Canada (Skinner et al., 2000) causing extensive crop yield losses through competition (Stachon \& Zimdahl, 1980) but it is also a major problem in disturbed sites in non-crop areas (White et al., 1993). As large-scale chemical control is detrimental to the environment and not economic on low-value land, classical biological control is an important alternative management strategy early on (McClay et al., 2002a). Hadroplontus litura oviposits into the midveins of Canada thistle rosette leaves in early spring and larvae mine down through the vein into the stem base and upper part of the tap root. Mature larvae emerge from the stem and pupate in the soil, and adults emerge to feed on C. arvense foliage in late summer (Zwölfer \& Harris, 1966; Peschken \& Wilkinson, 1981). Adults overwinter in the soil. According to Freese (1994), Canada thistle is the only known field host plant in Europe; however, Zwölfer \& Harris (1966) noted three records from Carduus defloratus L. (Asteraceae). Hadroplontus litura is established in Canada (Julien \& Griffiths, 1998) and, although the efficacy of $\mathrm{H}$. litura is inconsistent (McClay et al., 2002a), the insect appears to give acceptable control once populations reach high enough levels and when its use is combined with other control methods (Donald, 1990; Rees, 1990).

Scentless chamomile and Canada thistle are major weed species in or near fields of rapeseed, Brassica napus L., in Europe (Schroeder et al., 1993). In Canada, both weeds are widespread on the Canadian prairies (Manitoba, Saskatchewan and Alberta), the major canola production area (Donald, 1990; Woo et al., 1991). In this same region as well as the eastern provinces of Ontario and Québec, the invasive alien cabbage seedpod weevil, Ceutorhynchus obstrictus (Marsham) [=C. assimilis (Paykull); see Colonnelli (2004)] is a serious pest of canola. Adults feed on flower buds causing their destruction and larvae feed within seedpods, causing economic losses (Kuhlmann et al., 2002). In Europe, the parasitoid assemblage and its impact on C. obstrictus have been well documented (Williams, 2003) and several species are being evaluated for possible introduction into Canada as classical biological control agents. Those Ceutorhynchinae released to control weeds in cultivated crops will be at great risk of potential attack if agents released for biological control of C. obstrictus are not specific to that species (Kuhlmann et al., 2006a). Both M. edentulus and H. litura belong to the Ceutorhynchinae and have therefore been included in the proposed non-target species test list for candidate biological control agents of C. obstrictus (Kuhlmann et al., 2006a). Despite a number of studies on $M$. edentulus and $H$. litura, host-parasitoid association records are rather 
limited and it is unknown if parasitoid species attacking C. obstrictus will also attack the taxonomically related $H$. litura and $M$. edentulus.

To assess the potential risks of C. obstrictus parasitoids attacking related weed biological control agents, surveys are necessary in the area of origin to determine the hostparasitoid associations. These field studies provide guidance on ecological attributes of weevils that are important in selecting non-target species for host-specificity testing. Furthermore, it will facilitate better prediction of potential risks associated with introduction of candidate biological control agents of $C$. obstrictus into Canada. The objectives of this study were to: 1) describe the phenologies of $H$. litura and $M$. edentulus to determine if there is phenological overlap with C. obstrictus; 2) assess the parasitism levels, particularly by ectoparasitoids; and 3) determine the parasitoid assemblages associated with M. edentulus and H. litura.

\section{Material \& Methods}

\section{Field collected material}

All scentless chamomile and Canada thistle plants were collected in fallow fields, at field margins or along road sides in regions where canola fields, C. obstrictus and its common parasitoids co-occurred. Surveys for scentless chamomile and M. edentulus were carried out from May to July in 2003 and 2004 at eight sites in eastern Austria and three distinct regions in Hungary (Figure 1). Surveys for Canada thistle and H. litura were carried out in May and June in 2002, 2003 and 2004 at seven sites located in eastern France and three separate regions of Germany (Figure 1). As Canada thistle is a pioneer species, it very often grows along road sides or field margins. Preliminary studies showed that $H$. litura occurs more frequently in stable sites where it has had time to build up a population; thus, sites sampled were in wastelands or abandoned fields because they represented more stable habitats.

\section{Phenology of hosts}

Samples of 20 to 50 host plants were collected and dissected as often as every two days and at a maximum of 10-day intervals. For Canada thistle the whole plant was dissected, and for scentless chamomile the main shoot and three randomly chosen side-shoots were dissected to detect Ceutorhynchinae eggs and larvae which were determined to instar. The late third instar 
larvae of both $M$. edentulus and $H$. litura chew an exit hole through the parenchyma tissue to exit the plants and drop down into the soil where they pupate. Thus, the exit holes were

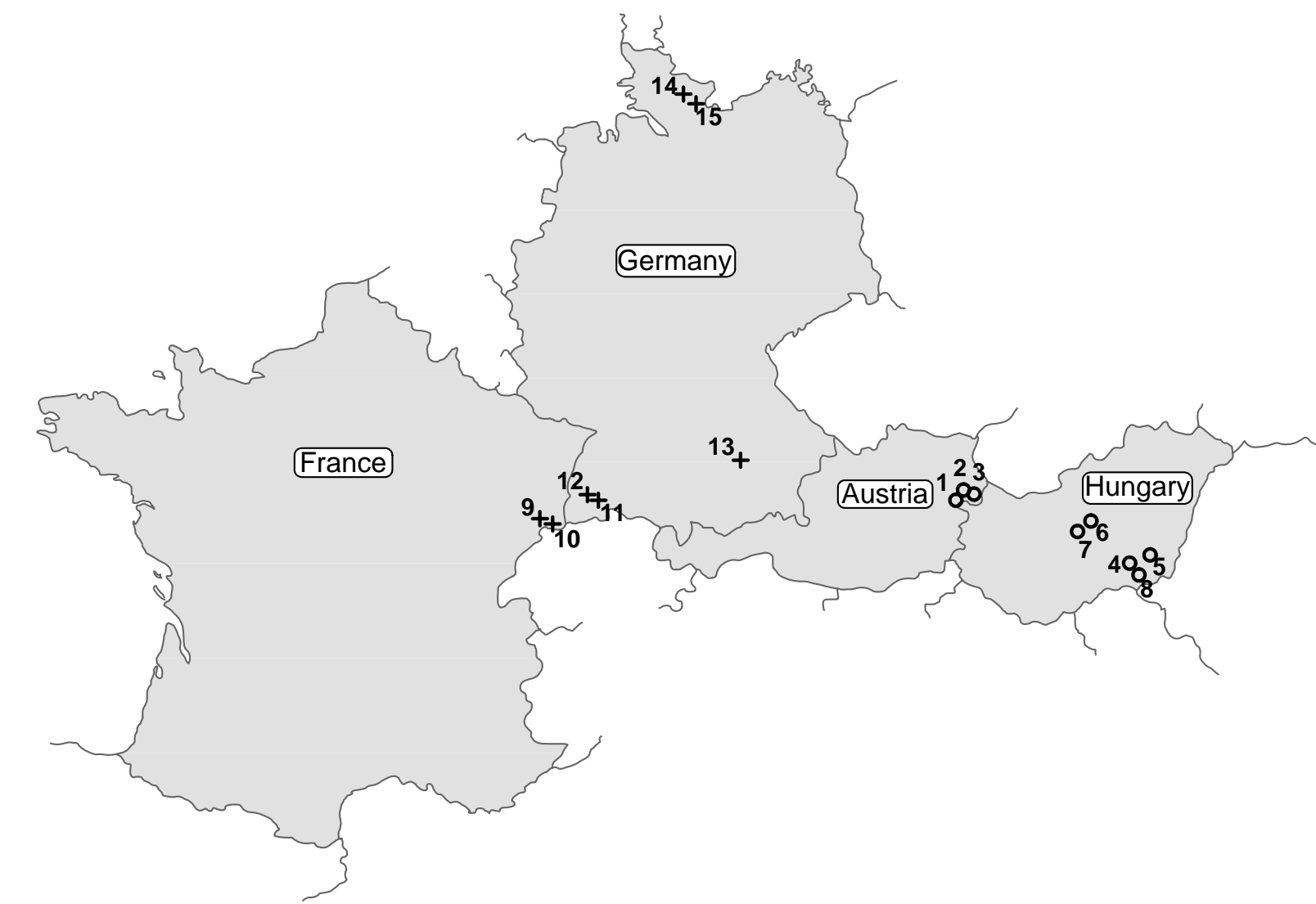

\begin{tabular}{|c|c|c|c|c|c|c|}
\hline \multirow{2}{*}{$\begin{array}{l}\text { Host plant } \\
\quad \text { / Ceutorhynchinae species }\end{array}$} & \multirow[t]{2}{*}{ Country } & \multirow[t]{2}{*}{ Region / Town } & \multirow{2}{*}{$\begin{array}{c}\text { Site } \\
\#\end{array}$} & \multicolumn{2}{|c|}{ Geographic coordinates } & \multirow{2}{*}{$\begin{array}{l}\text { Elevation } \\
(m .)\end{array}$} \\
\hline & & & & Lat. $N$ & Long. E & \\
\hline \multirow{8}{*}{$\begin{array}{l}\text { Tripleurospermum perforatum } \\
\text { / Microplontus edentulus }\end{array}$} & \multirow[t]{3}{*}{ Austria } & Burgenland / Eisenstadt & 1 & $47^{\circ} 49^{\prime} 22.57^{\prime \prime}$ & $16^{\circ} 32^{\prime} 18.77^{\prime \prime}$ & 148 \\
\hline & & Burgenland / Eisenstadt & 2 & $47^{\circ} 50^{\prime} 01.50^{\prime \prime}$ & $16^{\circ} 34^{\prime} 01.95^{\prime \prime}$ & 138 \\
\hline & & Burgenland / Eisenstadt & 3 & $47^{\circ} 48^{\prime} 54.06^{\prime \prime}$ & $16^{\circ} 32^{\prime} 16.45^{\prime \prime}$ & 149 \\
\hline & \multirow[t]{5}{*}{ Hungary } & Csongrad / Hodmezovasarhely & 4 & $46^{\circ} 22^{\prime} 01.13^{\prime \prime}$ & $20^{\circ} 13^{\prime} 17.51 "$ & 74 \\
\hline & & Bekes / Kardoskut & 5 & $46^{\circ} 27^{\prime} 45.83^{\prime \prime}$ & $20^{\circ} 32^{\prime} 37.14^{\prime \prime}$ & 79 \\
\hline & & Pest / Bugyi & 6 & $47^{\circ} 11^{\prime} 28.20^{\prime \prime}$ & $19^{\circ} 04^{\prime} 20.10^{\prime \prime}$ & 93 \\
\hline & & Pest / Kiskunlachaza & 7 & $47^{\circ} 11^{\prime} 15.66^{\prime \prime}$ & $19^{\circ} 02^{\prime} 38.58^{\prime \prime}$ & 96 \\
\hline & & Csongrad / Maroslele & 8 & $46^{\circ} 19^{\prime} 07.44^{\prime \prime}$ & $20^{\circ} 17^{\prime} 23.10^{\prime \prime}$ & 85 \\
\hline \multirow{7}{*}{$\begin{array}{l}\text { Cirsium arvense } \\
\text { / Hadroplontus litura }\end{array}$} & \multirow[t]{2}{*}{ France } & Alsace / Lucelle & 9 & $47^{\circ} 26 ' 23.93^{\prime \prime}$ & $07^{\circ} 18^{\prime} 06.15^{\prime \prime}$ & 480 \\
\hline & & Alsace / Lucelle & 10 & $47^{\circ} 26^{\prime} 21.93^{\prime \prime}$ & $07^{\circ} 19^{\prime} 12.99^{\prime \prime}$ & 525 \\
\hline & \multirow[t]{5}{*}{ Germany } & Southern Rhine valley / Grissheim & 11 & $47^{\circ} 52^{\prime} 02.78^{\prime \prime}$ & $07^{\circ} 36^{\prime} 33.27^{\prime \prime}$ & 213 \\
\hline & & Southern Rhine valley / Grissheim & 12 & $47^{\circ} 52^{\prime} 28.23^{\prime \prime}$ & $07^{\circ} 34^{\prime} 51.26^{\prime \prime}$ & 205 \\
\hline & & Bayern / Scheyern & 13 & $48^{\circ} 30^{\prime} 00.32^{\prime \prime}$ & $11^{\circ} 28^{\prime} 01.02^{\prime \prime}$ & 492 \\
\hline & & Schleswig Holstein / Stolpe & 14 & $54^{\circ} 09^{\prime} 00.00^{\prime \prime}$ & $10^{\circ} 46^{\prime} 58.08^{\prime \prime}$ & 19 \\
\hline & & Schleswig Holstein / Stolpe & 15 & $54^{\circ} 08^{\prime} 49.93^{\prime \prime}$ & $10^{\circ} 47^{\prime} 31.67^{\prime \prime}$ & 21 \\
\hline
\end{tabular}

Figure 1: Location of field collection sites of Tripleurospermum perforatum (Mérat) Laínz and Cirsium arvense (L.) Scopoli surveyed for the occurrence of Ceutorhynchus edentulus (Schultze) [o] and Hadroplontus litura (Fabricius) [+], respectively, in 2002, 2003, and 2004. 
recorded and taken into account to estimate the number of healthy third instar larvae that had left the plants. In cases of high larval infestation, several third instar larvae can exit the plant using the same hole, which might have led to an under-estimation of these numbers.

\section{Parasitism by Ectoparasitoids}

For each plant dissected, ectoparasitoid eggs and larvae found on parasitized host weevil larvae as well as ectoparasitoid pupae found near the remains of a consumed host body were recorded to estimate the parasitism level on each collection date for every selected field site. Mortality due to host feeding by ectoparasitoid adults was considered as an indirect effect of parasitism and recorded independently. Parasitism was calculated for each site as follows:

$$
\% \text { Parasitism }=\frac{\sum_{1}^{n} \text { paras. }}{\sum_{1}^{n} \text { avail.hosts }} \times 100=\frac{\sum_{\text {larv }}{ }^{\text {par }}+\sum_{\text {larv }}^{\dagger}+\sum_{\text {par }}{ }^{\text {alone }}}{\sum_{\text {larv }}{ }^{\text {healthy }}+\sum_{\text {larv }}{ }^{\dagger}+\sum_{\text {larv }}^{\dagger}+\sum_{\text {holes }}+\sum_{\text {par }}{ }^{\text {alone }}} \times 100
$$

where " $\sum_{1}^{n}$ paras." is the total number of parasitoids found in the plant; " $\sum_{1}^{n}$ avail.hosts" is the total number of hosts available for parasitism (second and third instar larvae) found in the plant; $\Sigma_{\text {larv }}{ }^{p a r}$ is the number of larvae found parasitized by an ectoparasitoid; $\Sigma_{\text {larv }}^{\dagger}$ is the number of larvae found dead with traces of host feeding like brownish punctures on the tegumen; $\Sigma_{\text {par }}$ alone is the number of parasitoids found alone near the remains of a consumed host, either as a pupa, or as a newly emerged adult which had not yet exited the plant; $\Sigma_{a r v}{ }^{\text {healthy }}$ is the number of healthy host larvae; $\Sigma_{\text {hole }}$ is the number of exit holes (made by healthy third instar larvae that have left the plant), found on the shoots during dissections.

A representative parasitism level was estimated for each site. The date on which the parasitism level was considered representative was that date on which the maximum number of healthy larvae still available for parasitism were present in the plant, i.e., just before the number of exit holes started to increase.

Host density was determined by considering the maximum number of hosts parasitized or available for parasitism during the season. Thus, only second and third instar larvae were used for calculations. Exit holes were recorded as equivalent to a single third instar larva that had exited the plant.

\section{Parasitoid assemblages}

Parasitoid eggs and larvae were reared on the host larvae they had been found parasitizing, and pupae were reared individually on a disc of filter paper in $5.5 \mathrm{~cm}$ diameter Petri dishes. 
Insects were reared in a climate chamber at $20 \pm 2^{\circ} \mathrm{C}, 70 \% \pm 10 \mathrm{RH}$, and $16 \mathrm{~h} \mathrm{~L}$ : $8 \mathrm{~h}$ D. The insects were checked daily until emergence of the adult parasitoid. Some groups emerged the same summer season that they were collected. Other groups, such as the Braconidae, overwintered in cocoons and emerged the following spring. Mortality was rather high over rearing and overwintering periods. Identification was possible only for adults which, directly after they had emerged in their individual rearing chamber, were killed using ethyl acetate. Every specimen was card-mounted, labelled with individual information, and stored for further identification purposes. All taxonomic identifications were made with the help of Hannes Baur at the Natural History Museum of Berne (NMBE), Switzerland, except for the Braconidae. These specimens were identified by Dr. C. van Achterberg, National Natural History Museum of Leiden, Netherlands. Where possible, Pteromalidae and Braconidae specimens were identified to species while other families were identified to genus.

Available information on life cycle, primary host association, hyperparasitism records, if existing, and plant host - weevil - parasitoid associations were obtained from the literature. Relevant references were obtained from the Taxapad programme (Yu et al., 2005) and the Universal Chalcidoidea Database (Noyes, 2006). Hannes Baur, NMBE, Switzerland, and Dr. Gary Gibson, Canadian National Collection of Insects, Ottawa, Canada were consulted for information on Chalcidoidea. Information on Ichneumonidea was obtained from Dr. K. Van Achterberg, Department of Entomology, National Natural History Museum of Leiden, Netherlands and Dr. Klaus Horstmann, University of Würzburg, Germany. Eurytomidae specimens were identified by Michael Gates, USDA-ARS, National Museum of Natural History, Washington DC, United States.

\section{Results}

\section{Microplontus edentulus on scentless chamomile}

\section{Phenology of hosts}

Sites surveyed in Hungary in 2004 all yielded similar results (Table 1). First instar larvae of M. edentulus were present in scentless chamomile shoots until the last week of June 2004 at all sites studied (Figure 2). Second instar larvae were observed from the second week of May to the first week of July. Third instar larvae appeared only for a short period (10 days to 2 
weeks) before the first mature larvae started to leave the plants very early in the season, beginning the first week of June. Weevil infestation levels were rather high, with densities between 4.0 \pm 0.6 and 7.5 \pm 0.9 larvae per plant in Austria in 2003, and between $1.9 \pm 0.5$ and $7.1 \pm 0.8$ larvae per plant in Hungary in 2004 (Table 1).

Table 1. Mean number $( \pm \mathrm{SE})$ of second and third instar larvae of Microplontus edentulus (Schultze) available for parasitism, and percentage parasitism observed in Austria in 2003 and Hungary in 2004.

\begin{tabular}{|c|c|c|c|c|c|c|}
\hline \multicolumn{2}{|r|}{ Location } & \multirow{2}{*}{$\begin{array}{c}\begin{array}{c}\text { Site } \\
\text { code }\end{array} \\
1\end{array}$} & \multicolumn{3}{|c|}{$\begin{array}{c}\text { Mean \# ( } \pm \mathrm{SE}) \text { of hosts } \\
\text { (L2/L3) per plant }\end{array}$} & \multirow{2}{*}{$\begin{array}{c}\% \\
\text { Parasitisim } \\
23.0\end{array}$} \\
\hline Austria & Burgenland / Eisenstadt & & 4.9 & \pm & 0.60 & \\
\hline & Burgenland / Eisenstadt & 2 & 7.5 & \pm & 0.92 & 52.3 \\
\hline & Burgenland / Eisenstadt & 3 & 4.0 & \pm & 0.57 & 1.9 \\
\hline \multirow[t]{5}{*}{ Hungary } & Csongrad / Hodmezovasarhely & 4 & 1.9 & \pm & 0.46 & 3.1 \\
\hline & Bekes / Kardoskut & 5 & 5.2 & \pm & 0.63 & 11.6 \\
\hline & Pest / Bugyi & 6 & 3.7 & \pm & 0.30 & 17.8 \\
\hline & Pest / Kiskunlachaza & 7 & 4.7 & \pm & 0.51 & 26.3 \\
\hline & Csongrad / Maroslele & 8 & 7.1 & \pm & 0.82 & 4.7 \\
\hline
\end{tabular}

\section{$\underline{\text { Phenology of ectoparasitoids }}$}

Ectoparasitoids were active from the third week of May and for a period of about one month (Figure 2). Parasitism was highest near Eisenstadt, Austria in 2003. Parasitism reached a maximum of $26.3 \%$ at the site \#7 near Kiskunlachaza on the 24 June 2004 . All healthy third instar larvae had left the shoots by the first week of July. Parasitism levels ranged from 1.9 to $52.3 \%$ in Austria in 2003 and from 3.1 to $26.3 \%$ in Hungary in 2004.

\section{$\underline{\text { Parasitoid assemblages }}$}

Parasitoids associated with weevils collected from scentless chamomile belonged to the hymenopteran families Pteromalidae, Eulophidae, Eurytomidae (Chalcidoidea), Braconidae, and Ichneumonidae (Ichneumonoideae) (Table 3). In Austria in 2003, seven species from four families and in Hungary in 2004 nine species from five families were represented. Regarding species identification, some parasitoid taxa are poorly known and taxonomic expertise is not available to determine their species identities. Available information such as life cycle, primary host association and hyperparasitism, and plant association are provided for all members of the parasitoid assemblage of $M$. edentulus in alphabetic order:

Bracon atrator Nees (Braconidae): 
Life cycle : Very little is known of the life cycle of this species. In this study we found $B$. atrator as a larval ectoparasitoid of M. edentulus. Adults laid eggs in spring and larvae built cocoons from which adults of the new generation emerged during the following spring.

Primary host associations: B. atrator has been recorded as a primary parasitoid of various hosts including Diptera (Agromyzidae, Tephritidae), Lepidoptera (Coleophoridae) and Coleoptera (Apionidae, Curculionidae) (Yu et al., 2005).
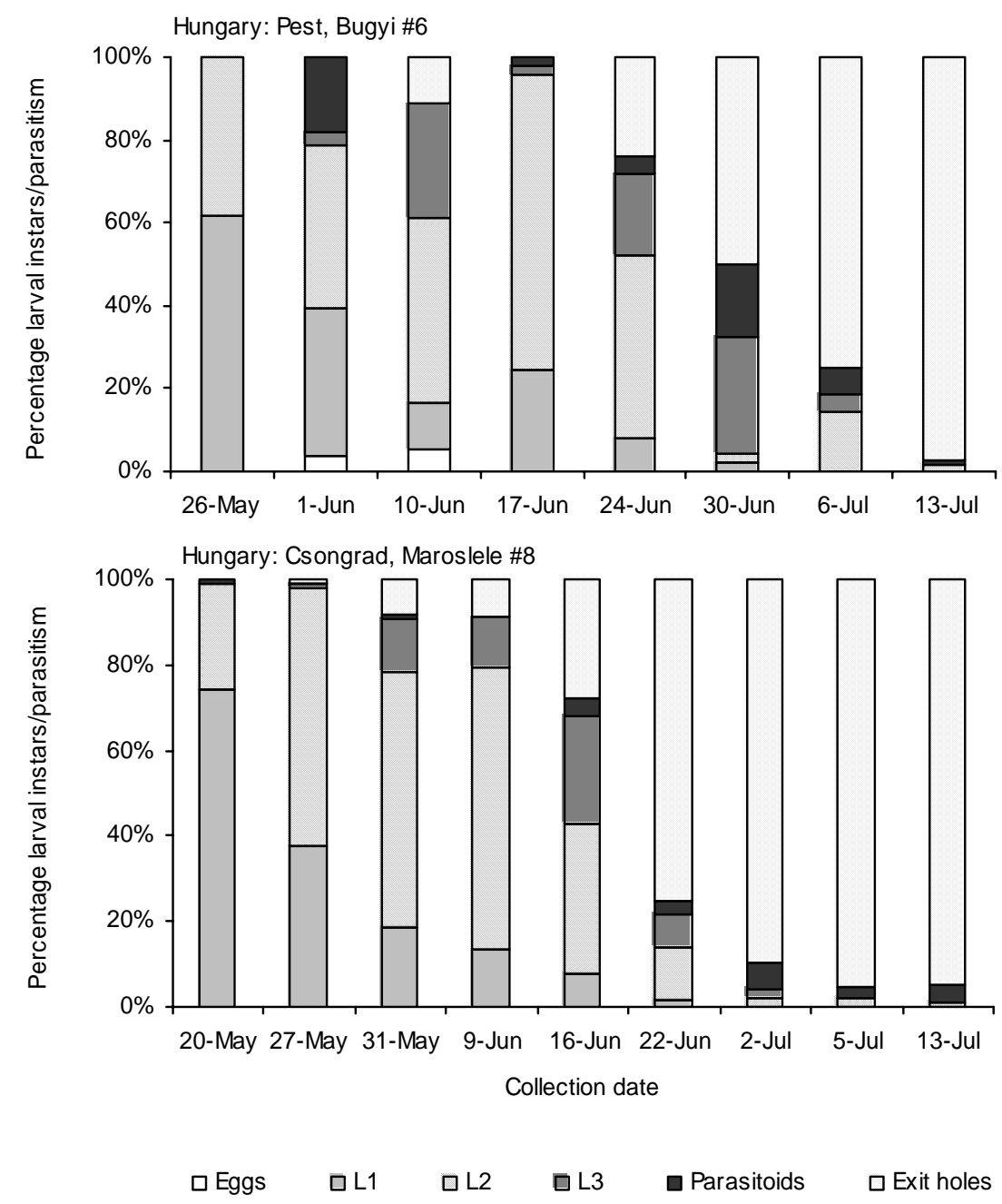

Figure 2. Proportion of eggs, larval instars 1-3 of Microplontus edentulus (Schultze), parasitism, and exit holes at Pest/Bugyi (site 6) and Csongrad/Maroslele, Hungary (site 8) between May and July in 2004.

Plant association: The species is associated with hosts feeding on Daucus carota L. (Apiaceae ) and Listera ovata (L.) R.Br. (Orchidaceae) (Yu et al., 2005). In this study the species was found on M. edentulus in shoots of scentless chamomile (Asteraceae). 
Bracon intercessor Nees (Braconidae):

Life cycle: Bracon intercessor is a solitary ectoparasitoid (Georgiev, 2000; Yu et al., 2005) that sometimes oviposits in galls formed by species such as sawflies (Hymenoptera: Tenthredinidae) in Salix species (Kopelke, 2003).

Primary host associations: Hosts of B. intercessor comprise species of Coleoptera (Cerambycidae, Curculionidae, Rhynchitidae), Hymenoptera (Tenthredinidae, Eurytomidae) and Lepidoptera (Gelechiidae, Tortricidae, Sesiidae) (Yu et al., 2005).

Plant association: Bracon intercessor develops in hosts associated with Poaceae, Umbellifereae, Fabaceae, Apiaceae and Asteraceae (Yu et al., 2005).

Chlorocytus sp. (Pteromalidae):

Life cycle: Species of the genus Chlorocytus are known to be primary larval or pupal ectoparasitoids, and in some cases hyperparasitoids (Graham, 1969). Adults appear in the field from May to July and occasionally August (Graham, 1969).

Primary host association and hyperparasitism if known: These species have a relatively diverse host range, parasitizing Coleoptera species such as Cerambycidae and Curculionidae (Yu et al., 2005). Records are known from Ceutorhynchus rapae Gyllenhal and C. adspersus Dietz hosts (Tremblay, 1968; Charlet et al., 2002). Diptera (Agromyzidae, Tephritidae) and Hymenoptera (Cephidae and non-gall forming Eurytomidae) are also hosts of Chlorocytus spp. (Noyes, 2006). In this study Eurytomidae species parasitized M. edentulus larvae at all sites where Chlorocytus spp. were present.

Plant association: Species of Chlorocytus develop in hosts associated with Asteraceae species (Graham, 1969; Charlet et al., 2002); however, the record here is the first association with T. perforatum. Chlorocytus spp. are also associated with plants from a wide range of families like Apiaceae, Fabaceae, Poaceae and Urticaceae (Graham, 1969; Boucek, 1977; Berg et al., 1995; Askew et al., 2001).

Closterocerus sp. (Pteromalidae):

Species of the genus Closterocerus have a very broad host range (Hansson, 1990; Hansson, 1994; Gumovski, 2001; Yu et al., 2005). Some species are primary parasitoids of leaf-miners and gall-formers, and others are also reported from Symphyta eggs (Argidae, Diprionidae), armored scales, and psyllids (Schauff, 1991; Hansson, 1996; Yu et al., 2005). 
Eupelmidae sp. (Pteromalidae):

The vast majority of Eupelmidae species are parasitoids and facultative hyperparasitoids on the immature stages of other insects, with hosts recorded in the orders Lepidoptera, Homoptera, Hymenoptera, Coleoptera, Neuroptera and Orthoptera (Noyes, 2006). A small number of species are predators on the eggs or larvae of various insects, or on the eggs of spiders and a few are solitary, primary endoparasitoids of eggs of Lepidoptera, Orthoptera and Hemiptera (Yu et al., 2005). Most eupelmids are solitary, but some species are gregarious (Clausen, 1940). Most are ectoparasitoids, including some that develop gregariously on dipterous pupae within puparia. A few species are solitary endoparasitoids of Coccoidea (Noyes, 2006).

Eurytoma curculionum Mayr (Pteromalidae):

Life cycle: The species is known to be a larval ectoparasitoid of concealed Coleoptera hosts (Fischer, 1965). It occurs less frequently as a hyperparasitoid attacking late instar larvae of chalcid wasps (Fischer, 1965). Eurytoma curculionum is bivoltine; adults emerge in late May and June whilst a partial second generation occurs in August (Fischer, 1965).

Primary host association: Eurytoma curcuilonum is known to be associated with species of Coleoptera such as Apionidae (Vidal, 1997), Buprestidae (Boucek, 1977) and Curculionidae (Dmoch, 1975a; Boucek, 1977). In this study, E. curculionum was found to be associated with M. edentulus.

Plant association: Records can be found of Eurytoma curcuilonum has been associated with hosts developing in Brassicaceae, Polygonaceae, Rubiaceae and Scrophulariaceae (Yu et al., 2005).

Shpegigaster sp. (Pteromalidae):

Life cycle: Sphegigaster sp. larval or pupal primary- or hyper- parasitoids are associated with gall-forming hosts (Graham, 1969). Adults fly from May to July and some species have more than one generation per year (Graham, 1969).

Primary host association and hyperparasitism: Primary hosts of Sphegigaster spp. comprise families of Coleoptera (Curculionidea), Diptera (Agromyzidae, Anthomyiidae, Chloropidae, Drosophilidae and Tephritidae) and Lepidoptera (Lyonetiidae) (Yu et al., 2005). Some Sphegigaster spp. are hyperparasitoids of Hymenoptera (Braconidae) (Graham, 1969). 
Plant association: Sphegigaster spp. are known to be associated with hosts developing in Aquifoliaceae, Brassicaceae, Fabaceae, Rubiaceae and Theaceae (Kumar, 1984; Potter \& Gordon, 1985).

Stenomalina gracilis Walker (Pteromalidae):

Life cycle: Stenomalina spp. are solitary primary larval or pupal ectoparasitoids. Adults can be observed in the field from June to October (Graham, 1969).

Primary host association: Stenomalina gracilis is associated with Coleoptera species in the weevil subfamily Ceutorhynchinae, such as C. obstrictus (Dmoch, 1975a), H. litura (Vidal, 1997), C. napi Gyllenhal, C. pallidactlylus (Marsham) and C. roberti Gyllenhal (Kuhlmann \& Mason, 2002). In this study, S. gracilis was associated with M. edentulus. Other known hosts of S. gracilis include Diptera (Agromyzidae, Calliphoridae, Cecidomyiidae, Chloropidae and Tephritidae), Hymenoptera (Cynipidae) and Lepidoptera (Tortricidae) (Noyes, 2006).

Plant association: Stenomalina gracilis has been associated with hosts developing on other Asteraceae, Brassicaceae, Cupressaceae and Fagaceae (Noyes, 2006) .

Syntomopus sp. (Pteromalidae):

Life cycle: Syntomopus species are primary pupal ectoparasitoids (Graham, 1969). Results obtained in this study indicate that Syntomopus sp. is a primary larval ectoparasitoid. Adults appear in the field in May and July-August, and there are probably two generations per year (Graham, 1969).

Primary host association and hyperparasitism if existing: Hosts of Syntomopus sp. include Diptera (Agromyzidae) and Lepidoptera (Pterophoridae) (Yu et al., 2005). The records from this study indicate that Syntomopus sp. is an ectoparasitoid of M. edentulus.

Plant association: Whereas Syntomopus spp. are known to develop in hosts associated with Asteraceae, no species had ever previously been reared from scentless chamomile. Other hosts of Syntomopus spp. feed on Apiaceae, Fabaceae, Solanaceae and Urticaceae (Graham, 1969; Vidal, 1993; Andriescu \& Mitroiu, 2001).

Triaspis sp. (Braconidae):

Life cycle : Species of the genus Triaspis are known to be larval or pupal endoparasitoids (Yu et al., 2005). In our study a single specimen was found, as a cocoon near the remains of a consumed larva of M. edentulus. 
Primary host associations: Triaspis species are known to be associated with hosts that include Coleoptera (Anobiidae, Attelabidae, Bostrichidae, Brentidae, Buprestidae, Cerambycidae, Chrysomelidae, Curculionidae), Diptera (Chlorophidae, Lonchaeidae, Tephritidae), and Lepidoptera (Choreutidae, Tischeridae, Tortricidae) (Yu et al., 2005). Graham (1991) recorded B. atrator as a hyperparasitoid on Baryscapus endemus (Walker) (Hymenoptera: Chalcidoidea: Eulophidae : Tetrastichinae).

Plant association : Records have been made of Triaspis species associated with hosts in Aesculus hippocastanum L. (Hippocastanaceae) and Poa pratensis L. (Poaceae) (Yu et al., 2005).

Trichomalus cf. gynetelus Walker (Pteromalidae):

Note: Identifications of $T$. cf. gynetelus and T. cf perfectus are difficult to confirm because single specimens of each were collected and a series of each species is needed to study variations in several morphological characters that differentiate the species

Life cycle: The related species, Trichomalus gynetelus is considered to be a solitary pupal ectoparasitoid (Graham, 1969). Little is known of its biology. In this study, a single specimen of a species near Trichomalus gynetelus was reared from a larva of M. edentulus.

Primary host association: This species is considered to have a host range restricted to the family Apionidae (Coleoptera). Our single record on $M$. edentulus is the first for Curculionidae.

Plant association: Associations have been recorded of T. gynetelus on hosts living in Asteraceae, Cupressaceae, Polygonaceae and Tamaricaceae (Vidal, 1993; Vidal, 1997; Askew et al., 2001).

Trichomalus cf. perfectus Walker (Pteromalidae):

Note: see Trichomalus cf. perfectus.

Life cycle: The related species, Trichomalus perfectus is a solitary larval ectoparasitoid; adults emerge from diapause in spring and fly from May until August (Graham, 1969). There is evidence of a possible partial second generation if acceptable hosts are present later in the season (Graham, 1969).

Primary host association: This species is restricted to species of Ceutorhynchinae (Coleoptera) (Noyes, 2006). However, a few records are known of T. perfectus reared from Diptera (Cecidomyiidae) (Vidal, 1993) and Hymenoptera (Torymidae) (Mitroiu, 2001). 
Plant association: Trichomalus perfectus is associated with hosts that develop in plant species among the families Asteraceae, Brassicaceae, Cupressaceae, Poaceae and Resedaceae (Dmoch, 1975a; Vidal, 1997; Kuhlmann \& Mason, 2002).

\section{Hadroplontus litura on Canada thistle}

\section{Phenology of Ceutorhynchinae hosts}

All three $H$. litura larval instars were observed in shoots of Canada thistle during the first week of May and at each sampling site (Figure 3). Healthy third instar larvae left the plant beginning in the second week of May. Infestation levels were rather low, with densities never reaching three larvae per plant at any of the sites studied. Although densities observed at the sites in France and Germany in 2004 were similar to those observed in 2003, the average temperatures observed in 2004 were in the normal seasonal range (compared to $2.0-3.5^{\circ} \mathrm{C}$ higher temperatures observed in 2003) and the phenology of H. litura was delayed by one week in 2004 at the three sites studied (Figure 3). Infestation levels were rather low, with densities between $1.2 \pm 0.4$ and $2.4 \pm 0.8$ larvae per plant in France, and between $0.4 \pm 0.2$ and 1.6 \pm 0.4 larvae per plant in Germany over the three-year survey (Table 2).

Table 2. Mean number $( \pm \mathrm{SE})$ of second and third instar larvae Hadroplontus litura (Fabricius) available for parasitism, and percentage parasitism observed at sites in France and Germany in 2002,2003 and 2004.

\begin{tabular}{|c|c|c|c|c|c|c|}
\hline \multicolumn{2}{|r|}{ Location } & \multirow{2}{*}{$\begin{array}{c}\text { Site } \\
\# \\
9\end{array}$} & \multicolumn{3}{|c|}{$\begin{array}{c}\text { Mean \# ( } \pm S E) \text { of hosts } \\
\text { (L2/L3) per plant }\end{array}$} & \multirow{2}{*}{$\begin{array}{c}\% \\
\text { Parasitisim } \\
12.5\end{array}$} \\
\hline \multirow[t]{5}{*}{ France } & Alsace / Lucelle & & 1.21 & \pm & 0.41 & \\
\hline & & 9 & 1.90 & \pm & 0.63 & 6.9 \\
\hline & & 9 & 2.35 & \pm & 0.81 & 47.1 \\
\hline & Alsace / Lucelle & 10 & 1.25 & \pm & 0.33 & 15.4 \\
\hline & & 10 & 0.85 & \pm & 0.38 & 43.8 \\
\hline \multirow[t]{5}{*}{ Germany } & Southern Rhine valley / Grissheim & 11 & 0.40 & \pm & 0.22 & 37.5 \\
\hline & Southern Rhine valley / Grissheim & 12 & 0.65 & \pm & 0.23 & 35.3 \\
\hline & Bayern / Scheyern & 13 & 1.55 & \pm & 0.44 & 9.3 \\
\hline & Schleswig Holstein / Stolpe & 14 & 0.56 & \pm & 0.18 & 18.8 \\
\hline & Schleswig Holstein / Stolpe & 15 & 0.48 & \pm & 0.20 & 15.4 \\
\hline
\end{tabular}

\section{Phenology of ectoparasitoids}

Ectoparasitoids were already present when collections were begun in the second week of May 2003 (Figure 3). However, parasitoid activity increased from the third week of May to reach maximum levels by the second week of June. Parasitism levels were between 6.9 and $47.1 \%$ 
in France and between 9.3 and $37.5 \%$ in Germany during the survey (Table 2). These parasitism levels might be slightly overestimated because healthy host larvae had already started to leave the plant when sampling was begun, and only the parasitized larvae and a low number of unparasitized third instar larvae were still present in the shoots.
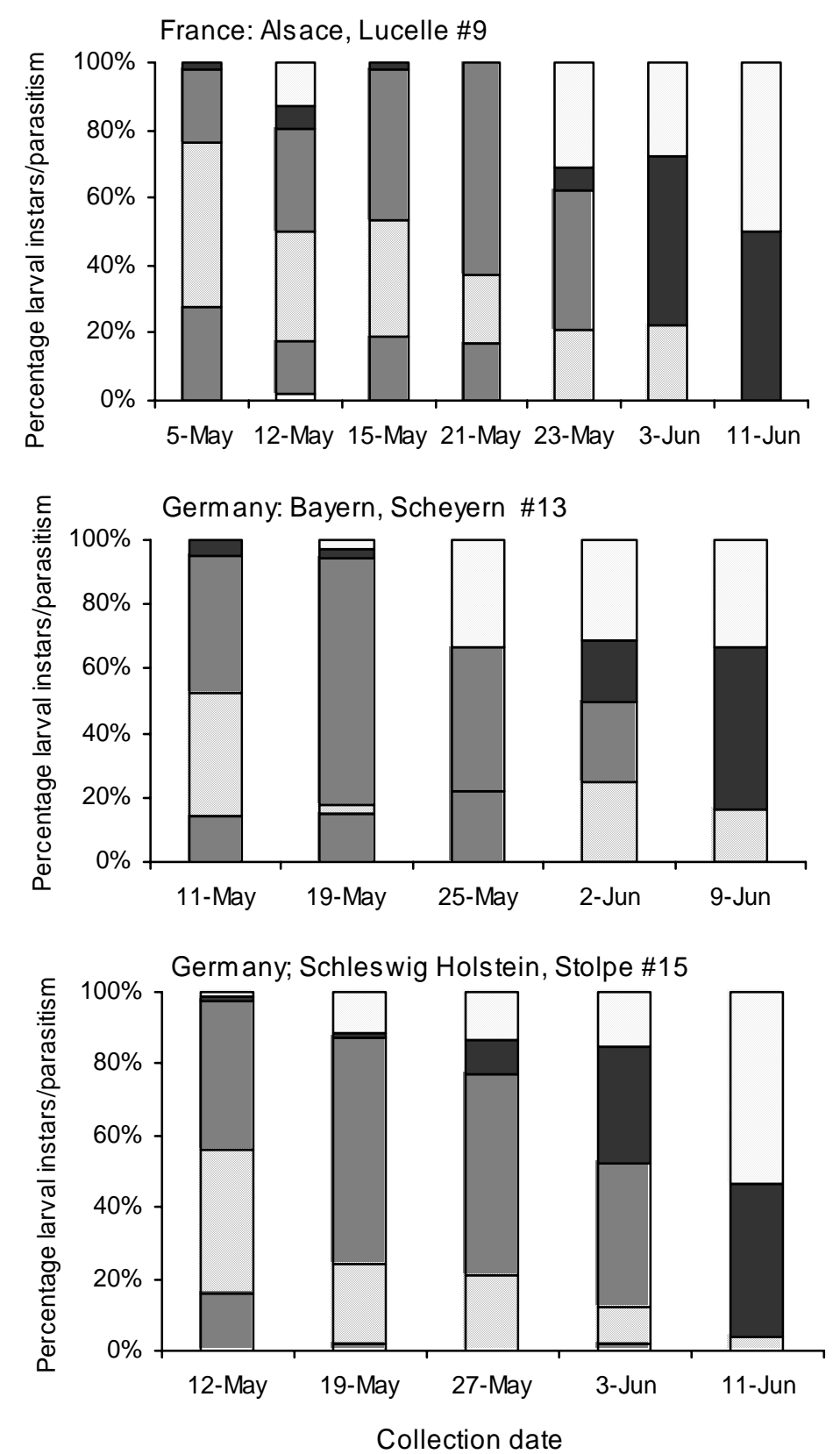

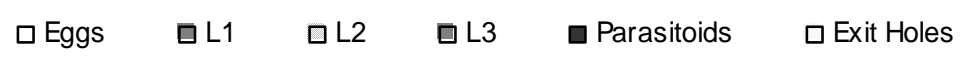

Figure 3. Proportion of larval instars 1-3 and pupae of Hadroplontus litura (Fabricius), exit holes, and parasitism at Alsace/Lucelle (site 9) in France, Bayern/Scheyern (site 13) and Schleswig Holstein/Stolpe (site 15) in Germany between May and June in 2003. 
The ectoparasitoids that were found in the shoots on the last sampling dates (the beginning of June) in 2003 and 2004 had already built cocoons in the shoots. Twenty-five and 15 adults emerged over a one month period from these cocoons in April of 2003 and 2004, respectively.

\section{Parasitoid assemblage}

Bracon intercessor Nees was the only species found parasitizing $H$. litura larvae at all sites in $2003(n=25)$ and $2004(n=15)$. These data contrast with the diverse parasitoid complex associated with $M$. edentulus in scentless chamomile stems.

Bracon intercessor Nees (Braconidae):

Life cycle: Bracon intercessor is an ectoparasitoid that sometimes oviposits in root galls made by Cleoninae weevils (Coleoptera: Curculionidae) (Volovnik, 1994; Yu et al., 2005). Georgiev (2000) stated that the species has a gregarious life style. In this study B. intercessor was reared as a solitary larval ectoparasitoid of $H$. litura.

Primary host associations: The primary hosts of B. intercessor comprise Coleoptera (Cerambycidae, Curculionidae, Rhynchitidae), Hymenoptera (Tenthredinidae, Eurytomidae) and Lepidoptera (Gelechiidae, Tortricidae, Sesiidae) (Yu et al., 2005).

Plant association: Bracon intercessor develops in hosts associated with Poaceae, Umbellifereae, Fabaceae, Apiaceae and Asteraceae (Yu et al., 2005).

\section{Discussion}

The phenology of the Ceutorhynchinae hosts H. litura and M. edentulus observed in this study confirms the findings reported by Zwölfer \& Harris (1966), Hinz et al. (1996) and McClay et al. (2002b). Microplontus edentulus oviposits in stems of scentless chamomile in May, and larvae develop through three larval instars between May and July, exiting the stems to pupate in the soil. Hadroplontus litura lays eggs in stems of Canada thistle, and larvae develop during May and June. Larvae of C. obstrictus also develop in canola pods during May to July (Bonnemaison, 1957) confirming that its phenology overlaps with those of $M$. edentulus and $H$. litura in the field. The geographical distributions of these three species also overlap in Europe (Bonnemaison, 1957; Zwölfer \& Harris, 1966; Peschken \& Wilkinson, 1981; Hinz et al., 1996; McClay et al., 2002b; Dosdall \& Moisey, 2004). The phenological and geographical overlap of target (C. obstrictus) and non-target (H. litura and M. edentulus) 
species clearly indicates a high risk that parasitoids of the target species could attack the two non-target species based on the criteria proposed by Kuhlmann et al. (2006a). Trichomalus perfectus and $M$. morys are the two most common parasitoids of $C$. obstrictus, and combined with the less common S. gracilis, these three species account for up to $90 \%$ of parasitism in Europe (2003). Of these parasitoids, T. perfectus and M. morys are potential candidates for introduction as biological control agents against C. obstrictus in North America (Kuhlmann et al., 2002).

Gibson et al. (2005) demonstrated that T. perfectus and M. morys are not present in North America. Stenomalina gracilis, however, occurs on C. obstrictus in low numbers in British Columbia (Gibson et al., in press). Prior to introduction of T. perfectus and M. morys and before considering S. gracilis for inundative biological control, it is essential to document their host ranges so that any actions taken are only with those parasitoids that are specific to ensure potential non-target effects are avoided. Assessment of the host specificity of these candidate parasitoids in their area of origin facilitates accurate prediction of potential nontarget host impacts in the area of introduction as proposed by Kuhlmann et al. (2006a).

Our results determined several new host-parasitoid associations. Chlorocytus spp. were associated with M. edentulus for the first time and E. curculionum was associated with M. edentulus larvae at all sites where Chlorocytus spp. were present. Although Chlorocytus spp. are known to be hyperparasitoids of Eurytomidae (Graham, 1969) they were found only as primary larval ectoparasitoids of $M$. edentulus. Species of Chlorocytus develop in hosts associated with Asteraceae species; however, the association with hosts feeding on scentless chamomile reported here is new.

Stenomalina gracilis is associated with Ceutorhynchinae species such as C. obstrictus (Dmoch, 1975), H. litura (Vidal, 1997), C. napi, C. pallidactylus, and C. roberti (Kuhlmann \& Mason, 2002). In this study, S. gracilis was associated with M. edentulus for the first time.

Our results indicated that Syntomopus sp. is a primary larval ectoparasitoid, whereas Syntomopus spp. have previously only been recorded as primary pupal ectoparasitoids (Graham, 1969). Furthermore, Syntomopus spp. hosts recorded in the literature include Diptera (Agromyzidae) and Lepidoptera (Pterophoridae) (Yu et al., 2005). The records of Syntomopus sp. parasitizing M. edentulus comprise a new association.

Trichomalus gynetelus had been recorded as parasitizing weevils in the genus Apion (Vidal, 1993; Askew et al., 2001). The single specimen of T. sp. nr. gynetelus reared from a larva of M. edentulus may represent a new family (Curculionidae) association for T. gynetelus or T. sp. nr. gynetelus may simply be another species that attacks a different host group of 
Coleoptera. Identifications of $T$. sp. nr. gynetelus and $T$. cf perfectus are difficult to confirm because single specimens of each were collected and a series of each species is needed to study variations in several morphological characters that differentiate the species.

Table 3. Species and their proportions of the parasitoid assemblages associated with Microplontus edentulus (Schultze) for each sample site in 2003 and 2004.

\begin{tabular}{|c|c|c|c|c|}
\hline Year & Site & Parasitoid species & \# Individuals & $\%$ \\
\hline \multirow[t]{13}{*}{2003} & Austria & Stenomalina gracilis Walker ${ }^{1}$ & 2 & 25,0 \\
\hline & \multirow[t]{4}{*}{ Eisenstadt-Site 1} & Eupelmus sp. ${ }^{4}$ & 2 & 25,0 \\
\hline & & Bracon intercessor Nees ${ }^{5}$ & 2 & 25,0 \\
\hline & & Trichomalus cf. perfectus Walker ${ }^{1}$ & 1 & 12,5 \\
\hline & & Eupelmus sp. ${ }^{4}$ & 1 & 12,5 \\
\hline & Austria & Stenomalina gracilis Walker ${ }^{1}$ & 14 & 66,7 \\
\hline & \multirow[t]{3}{*}{ Eisenstadt-Site 2} & Eurytoma curculionum Mayr ${ }^{3}$ & 5 & 23,8 \\
\hline & & Trichomalus cf. gynetelus Walker ${ }^{1}$ & 1 & 4,8 \\
\hline & & Bracon intercessor Nees ${ }^{5}$ & 1 & 4,8 \\
\hline & Austria & Eurytoma curculionum Mayr ${ }^{3}$ & 3 & 50,0 \\
\hline & \multirow[t]{3}{*}{ Eisenstadt-Site 3} & Stenomalina gracilis Walker ${ }^{1}$ & 1 & 16,7 \\
\hline & & Syntomopus sp. ${ }^{1}$ & 1 & 16,7 \\
\hline & & Triaspis sp. ${ }^{5}$ & 1 & 16,7 \\
\hline \multirow[t]{23}{*}{2004} & Hungary & Chlorocytus sp. $1^{1}$ & 7 & 36,9 \\
\hline & \multirow[t]{5}{*}{ Bekes-Site 5} & Eurytoma curculionum Mayr ${ }^{3}$ & 5 & 26,3 \\
\hline & & Bracon intercessor Nees ${ }^{5}$ & 2 & 10,5 \\
\hline & & Chlorocytus sp. $2^{1}$ & 2 & 10,5 \\
\hline & & Ichneumonidae $^{6}$ & 2 & 10,5 \\
\hline & & Closterocerus sp. ${ }^{2}$ & 1 & 5,3 \\
\hline & Hungary & Chlorocytus sp. $1^{1}$ & 2 & 22,2 \\
\hline & \multirow[t]{5}{*}{ Pest- Site 6} & Chlorocytus sp. $2^{1}$ & 2 & 22,2 \\
\hline & & Sphegigaster sp. ${ }^{1}$ & 2 & 22,2 \\
\hline & & Eurytoma curculionum Mayr ${ }^{3}$ & 1 & 11,1 \\
\hline & & Stenomalina gracilis Walker1 & 1 & 11,1 \\
\hline & & Syntomopus sp. ${ }^{1}$ & 1 & 11,1 \\
\hline & Hungary & Eurytoma curculionum Mayr ${ }^{3}$ & 5 & 33,3 \\
\hline & \multirow[t]{5}{*}{ Pest- Site 7} & Bracon intercessor $\mathrm{Nees}^{5}$ & 3 & 20,0 \\
\hline & & Bracon atrator $\mathrm{Nees}^{5}$ & 2 & 13,3 \\
\hline & & Stenomalina gracilis Walker ${ }^{1}$ & 2 & 13,3 \\
\hline & & Syntomopus sp. ${ }^{1}$ & 2 & 13,3 \\
\hline & & Sphegigaster sp. ${ }^{1}$ & 1 & 6,7 \\
\hline & Hungary & Bracon atrator $\mathrm{Nees}^{5}$ & 2 & 22,2 \\
\hline & \multirow[t]{4}{*}{ Csongrad-Site 8} & Chlorocytus sp. $1^{1}$ & 2 & 22,2 \\
\hline & & Eurytoma curculionum Mayr ${ }^{3}$ & 2 & 22,2 \\
\hline & & Syntomopus sp. ${ }^{1}$ & 2 & 22,2 \\
\hline & & Sphegigaster sp. ${ }^{1}$ & 1 & 11,1 \\
\hline
\end{tabular}

Chalcidoidea : 1Pteromalidae, 2 Eulophidae, 3Eurytomidae, 4Eupelmidae; Ichneumonoidea: 5Braconidae, 6Ichneumonidae 
Overall parasitism levels were equivalent between $M$. edentulus and $H$. litura, on average respectively $17.6 \%(1.9-53.3)$ and $24.2 \%(6.9-57.1)$ of all the host larvae available to parasitoids were parasitized. Among the thirteen species that represent the parasitoid assemblage of $M$. edentulus, $75 \%$ of the composition is represented by six species, $E$. curculionum (24\%), S. gracilis (23\%), Braconidae spp. (15\%) and Chlorocytus sp. 1 (13\%) respectively, the other $25 \%$ being shared among nine species. Our results for parasitism of $H$. litura are confirmed by results of Freese (1997) who found 24\% parasitism at various sites in three regions of Germany. Furthermore, the braconid wasp B. intercessor is one of the four most common species in the parasitoid assemblage of $M$. edentulus, and was found to be the only species associated with $H$. litura in our study, a new record for that species. In fact, very few studies have dealt with parasitism of H. litura. However, Freese (1997) found another species of Braconidae, Bracon immunator Nees, attacking the weevil, and found $B$. intercessor in stems of C. arvense as well, but associated with Mordellistema sp. (Coleoptera: Mordellidae) and not with $H$. litura.

Exclusively idiobiont parasitoids were found on both $M$. edentulus and $H$. litura parasitizing larval instars or pupae in our study. Breadth of host range is very closely correlated with the koinobiont / idiobiont characterization (1986). The parasitoid complex of a given host appears to be reasonably constant over much of the host's geographic range (Askew \& Shaw, 1986), and our findings confirm this for the parasitoid assemblages associated with $M$. edentulus and H. litura in four European countries: at least three of the four most represented species parasitizing M. edentulus (Eurytoma curculionum, S. gracilis, Braconidae spp., Chlorocytus spp.) were always represented, independently of the country and survey sites, and the single species, B. intercessor, associated with $H$. litura, occurred at all sites where parasitism was observed. Furthermore, Askew \& Shaw (1986) also stated that similar ectoparasitoid complexes attack taxonomically and ecologically related hosts in widely separated geographic areas. We could not confirm this because we looked only at two Ceutorhynchinae species, although $M$. edentulus was associated with a much broader parasitoid assemblage (thirteen species) than $H$. litura (a single parasitoid species). Nevertheless, Mills (1994) gives a partial answer, stating that the major correlate of species richness in the parasitoid communities of phytophagous insects is the host larval feeding site. It has been postulated that plant species of high exposure are subject to highest levels of colonization by herbivorous insects, and it would follow that parasitoids should find the greatest range of hosts on such plants (Askew \& Shaw, 1986). This hypothesis is well illustrated in our study where: 1) H. litura is a stem and root feeder and mines into the thistle 
rosette, at ground level, in spring and feeds downward into the root (i.e. it is subterranean and difficult to find); and 2) M. edentulus mine the aerial stems of scentless chamomile plants and move upward to the seed heads (i.e. it is easy to find). Furthermore, Hawkins (1994) demonstrates that when hosts are ranked on a scale of increasing concealment within the food-plant or soil, parasitoid species richness is dome-shaped, with borers supporting in general more parasitoid species than root-feeders. Therefore, Hawkins (1994) argues that there is evidence that host feeding niche can be used as a template against which to examine other forces that influence community size and structure, such as feeding biology or host taxonomy. As a matter of fact, the only representative of the family Braconidae, $B$. intercessor, was the only species found parasitizing both host species, which could lead to the hypothesis that some braconid wasps might be more adept at finding subterreanean hosts than pteromalids.

Our results show that at least three (E. curculionum, Chlorocytus spp., S. gracilis) and possibly two more (T. sp. nr. gynetelus and $T$. cf. perfectus) species parasitizing $M$. edentulus in shoots of scentless chamomile do occur in the parasitoid assemblages associated with $C$. obstrictus in Europe as shown by Williams (2003). In contrast, the parasitoid assemblage associated with $H$. litura does not share any species with that of $C$. obstrictus. These findings indicate the importance of considering feeding niche as an important criterion when developing a non-target species test list for host range testing of potential biological control agents as proposed by Kuhlmann et al. (2006a; 2006b).

Despite phenological overlap of $M$. edentulus, $H$. litura, and C. obstrictus, and overlapping geographical distributions in Europe, M. morys did not parasitize non-target hosts. Furthermore, we also found no evidence that $T$. perfectus attacks these species. In contrast, S. gracilis parasitized M. edentulus at five of the seven sites surveyed during two years, in Austria and Hungary.

The concerns regarding potential non-target effects of invertebrate biological control agents of arthropods has risen during the last decade and an increasing number of studies have addressed this topic (Babendreier et al., 2005). Moreover, understanding the population dynamics of species of economic importance is still hampered by the insufficient knowledge of the natural enemy complexes that may play an important role in the regulation of herbivorous insects (Vidal, 2003). In the case of biological control of C. obstrictus in Canada, our studies, apart from providing ecological baseline data on parasitoid complexes of nontarget species, show that, in their area of origin, T. perfectus and M. morys do not attack $M$. edentulus or H. litura. These results constitute a first step at understanding the risks associated 
with an introduction of these potential agents to North America for biological control of $C$. obstrictus. In the event that these two parasitoids are introduced to Canada in the future, it appears that they would pose no risk to either M. edentulus or H. litura. However, S. gracilis poses some risk to M. edentulus, and therefore should not be further considered because its release or redistribution would lead to conflicting situations with weed biological control. 


\section{Acknowledgments}

We acknowledge Emmanuel Cuenot (France), Virginia Larraz (Spain), Leonore Lovis (Switzerland), Gabor Nagy (Hungary), Fezekas Janos (Hungary), Alicia Leroux (Canada), MSc Tara Gariepy (Canada), Kim Riley (Canada), Lars Andreassen (Canada), MSc Leyla Valdivia Buitriago (Peru), MSc Rike Stelkens (Germany) and MSc Stephen Maggins (Ireland) for their precious help as part of the CABI Agricultural Pest Research dissection team. Maren Belde (Technische Universität, Munich, Germany) and MSc Beate Klander (Christian-Albrechts Universtität, Kiel, Germany) for finding collection sites of Canada thistle in Germany. Dr. Scheibelreiter (Vienna, Austria) assisted with collections of scentless chamomile in Austria in 2003. We appreciated the fruitful discussions with Dr. André Gassmann, Dr. Hariet Hinz, Dr. Stefan Toepfer (all CABI) and acknowledge them as well for information exchanged on collection sites of both scentless chamomile and Canada thistle in various European countries. Mr. Hannes Baur, Natural History Museum, Bern, Switzerland and Dr. Gary Gibson, Canadian National Collection, Ottawa, Ontario, Canada provided precious help for identification of the chalcid parasitoids. Michael Gates, USDA-ARS, National Museum of Natural History, Washington DC, United States identified the eurytomid parasitoids. This work was funded by Agriculture and Agri-Food Canada, AAFC's Pest Management Research Centre Project PRR03-370 and the Alberta Agricultural Research Institute. 


\section{References}

Andriescu, I. \& M. D. Mitroiu (2001). Contributions to the knowledge of the pteromalids (Hymenoptera, Chalcidoidea, Pteromalidae) from David's Valley hay fields natural reserve, Iasi (II). Analele Stiintifice ale Universitatii "Al. I. Cuza" din Iasi. Serie Noua - Biologie Animala 47, 21-28.

Askew, R. R., J. Blasco-Zumeta \& J. Pujade-Villar (2001). Chalcidoidea and Mymarommatoidea (Hymenoptera) of a Juniperus thurifera L. forest of Los Monegros region, Zaragosa. Monografias Sociedad Entomológica Aragonesa 4, 17pp.

Askew, R. R. \& S. R. Shaw (1986). Parasitoid Communities. In: D. Greathead and J. Waage (Eds.) Insect Parasitoids. Academic Press, Imperial College, London. 225-229.

Babendreier, D., F. Bigler \& U. Kuhlmann (2005). Methods used to assess non-target effects of invertebrate biological control agents of arthropod pests. BioControl 50 (6), 821870 .

Bacher, S. (1993). Vergleichende ökologische Studien über zwei sympatrische Rüsselkäferarten an der Geruchlosen Kamille (Tripleurospermum perforatum). Diplomarbeit, Zoologisches Institut, Christian-Albrechts-Universität zu Kiel. 82 pp.

Berg, H., O. Ankasah \& K. Hassan (1995). Soybean stem fly, Melanagromyza sojae (Diptera: Agromyzidae), on Sumatra: seasonal incidence and the role of parasitism. International Journal of Pest Management 41 (3), 127-133.

Bonnemaison, L. (1957). Le charancon des siliques (Ceutorhynchus assimilis Payk.) Biologie et Méthodes de lutte. Annales de l'institut national de la recherche agronomique Serie C: Annales des Epiphytes 8 (IV), 387-542.

Boucek, Z. (1977). A faunistic review of the Yugoslavian Chalcidoidea (Parasitic Hymenoptera). Acta Entomologica Jugoslavica 13 (Supppl. 32), 1-145.

Charlet, L. D., J. S. Armstrong \& G. L. Hein (2002). Sunflower stem weevil and its larval parasitoids on the central and northern plains of the USA. BioControl 47 (5), 513-523.

Clausen, C. P. (1940). Entomophagous Insects. In: A. F. Shull (Ed.) McGraw-Hill Publications in the Zoological Sciences. McGraw-Hill, New York. 120-131.

Colonnelli, E. (2004). Catalogue of Ceutorhynchinae of the world, with key to genera. Argania edito, Balmes, Barcelona. 124 pp. 
Coombs, E. M. (2004). Factors that affect successful establishment of biological control agents. In: E. M. Coombs, J. K. Clark, G. L. Piper and A. F. Cofrancesco (Eds.) Biological Control of Invasive Plants in the United States. Oregon State University Press, Corvallis, OR, United States. 85-94.

Dmoch, J. (1975). Study on the parasites of the cabbage seedpod weevil (Ceutorhynchus assimilis Payk.). I. Species composition and economic importance of the larval ectoparasites. Roczniki Nauk Rolniczych 5 (1), 99-112.

Donald, W. W. (1990). Management and control of Canada thistle (Cirsium arvense). Reviews of Weed Science 5, 193-250.

Dosdall, L. M. \& D. W. A. Moisey (2004). Developmental biology of the cabbage seedpod weevil, Ceutorhynchus obstrictus (Coleoptera: Curculionidae), in spring canola, Brassica napus, in western Canada. Annals of the Entomological Society of America 97 (3), 458-465.

Fischer, J. P. (1965). A contribution to the biology of Eurytoma curculionum Mayr (Hym., Eurytomidae). Entomophaga 10 (4), 317-318.

Freese, G. (1994). The insect complexes associated with the stems of seven thistle species. Entomologia Generalis 19, 191-207.

Freese, G. (1997). Insektenkomplexe in pflanzenstengeln. Bayreuth Institut für Terrestrische Ökosystemforschung, Bayreuth University, Germany. 198 pp.

Gassmann, A. (1995). Europe as a source of biological control agents of exotic invasive weeds: status and implications. Mitteilungen der Schweizerischen Entomologischen Gesellchaft 68, 313-322.

Georgiev, G. (2000). Studies on larval parasitoids of Paranthrene tabaniformis (Rott.) (Lepidoptera: Sesiidae) on urban poplars (Populus spp.) in Sofia, Bulgaria. Annals of Forestry Science 57, 181-186.

Gibson, G. A. P., H. Baur, B. Ulmer, L. Dosdall \& F. J. Muller (2005). On the misidentification of the chalcid (Hymenoptera: Chalcidoidea) parasitoids of the cabbage seedpod weevil (Coleoptera: Curculionidae) in North America. The Canadian Entomologist 137, 381-403.

Gibson, G. A. P., D. R. Gillespie \& L. M. Dosdall (in press). The species of Chalcidoidea (Hymenoptera) introduced to North America for biological control of the cabbage seedpod weevil, and the first recovery of Stenomalina gracilis (Chalcidoidea: Pteromalidae). The Canadian Entomologist.

Graham, M. W. R. (1969). The Pteromalidae of North-Western Europe (Hymenoptera: Chalcidoidea). Bulletin of the British Museum (Natural History) Entomology (Suppl.16), 908pp. 
Graham, M. W. R. (1991). A reclassification of the European Tetrastichinae (Hymenoptera: Eulophidae): Revision of the remaining genera. Memoirs of the American Entomological Institute 49, 322 pp.

Gumovski, A. V. (2001). The status of some genera allied to Chrysonotomyia and Closterocerus (Hymenoptera: Eulophidae, Entedoninae), with description of a new species from Dominican amber. Phegea 29 (4), 125-141.

Hansson, C. (1990). A taxonomic study on the Palearctic species of Chrysonotomyia Ashmead and Neochrysocharis Kurdjumov (Hymenoptera: Eulophidae). Entomologica Scandinavica 21, 29-52.

Hansson, C. (1994). Re-evaluation of the genus Closterocerus Westwood (Hymenoptera: Eulophidae), with a revision of the Nearctic species. Entomologica Scandinavica 25, $1-25$.

Hansson, C. (1996). Taxonomic revision of the Nearctic species of Omphale Haliday (Hymenoptera: Eulophidae). Entomologica Scandinavica (suppl. 49), 1-78.

Hawkins, B. A. (1994). Pattern and process in host-parasitoid interactions. Cambridge University Press. 183 pp.

Hinz, H. L., S. Bacher, A. S. McClay \& R. A. DeClerk-Floate (1996). Microplontus (=Ceutorhynchus) edentulus (Schultz.) (Col.:Curculionidae), a candidate for the biological control of scentless chamomile in North America - Revised Final Report, International Institute of Biological Control. Delémont, Switzerland. 44pp.

Hinz, H. L. \& A. S. McClay (2000). Ten years of scentless chamomile: prospects for the biological control of a weed of cultivated land. In: N. R. Spencer (Ed.) Proceedings of the Xth International Symposium on Biological Control of Weeds. Bozeman, Montana. 537-550.

Julien, M. H. \& M. W. Griffiths (1998). Biological control of weeds - A world Catalogue of Agents and their target weeds. CABI Publishing, Wallingford, Oxon, UK. 223 pp.

Kopelke, J. P. (2003). Natural enemies of gall-forming sawflies on willows (Salix spp) (Hymenoptera: Tenthredinidae: Euura, Phyllocolpa, Pontania). Entomologia Generalis 26 (4), 277-312.

Kuhlmann, U., L. M. Dosdall \& P. G. Mason (2002). Ceutorhynchus obstrictus (Marsham), cabbage seedpod weevil (Coleoptera: Curculionidae). In: P. G. Mason and J. T. Huber (Eds.) Biological Control Programmes in Canada, 1981-2000. CABI Publishing, Wallingford, Oxon, U.K. 52-58.

Kuhlmann, U. \& P. G. Mason (2002). Use of field host range surveys for selecting candidate non-target species for physiological host specificity testing of entomophagous biological control agents. In: R. G. Van Driesche (Ed.) Proceedings of the 1st 
International Symposium on Biological Control of Arthropods. United States Department of Agriculture, Forest Service, Washington, USA Hawaii. 370-377.

Kuhlmann, U., P. G. Mason, H. L. Hinz, B. Blossey, R. A. De Clerck-Floate, L. Dosdall, J. P. McCaffrey, M. Schwarzlaender, O. Olfert, J. Brodeur, A. S. McClay \& R. N. Wiedenmann (2006a). Avoiding conflicts between insect and weed biological control: selection of non-target species for test list to assess host specificity of cabbage seedpod weevil parasitoids. Journal of Applied Entomology 130 (3), 129-141.

Kuhlmann, U., U. Schaffner \& P. G. Mason (2006b). Selection of non-target species for host specificity testing. In: F. Bigler, D. Babendreier and U. Kuhlmann (Eds.) Environmental impact of invertebrates for biological control of Arthropods: Methods and risk assessment. CABI Publishing., Wallingford, Oxon, UK. 15-37.

Kumar, A. (1984). Incidence of pupal parasitism on Chromatomyia horticola (Gour.) (Diptera: Agromyzidae) in some parts of Uttar Pradesh. Annals of Entomology 2 (2), $37-44$.

Mason, P. G. \& J. T. Huber (Eds.) (2002). Biological control programmes in Canada, 19812000. CABI Publishing, Wallingford, UK. 583 pp.

McClay, A. S., R. S. Bourchier, P. A. Butts \& D. P. Peschken (2002a). Cirsium arvense (L.) Scopoli, Canada thistle (Asteraceae). In: P. G. Mason and J. T. Huber (Eds.) Biological Control Programmes in Canada, 1981-2000. CABI Publishing, Wallingford, Oxon, UK. 318-330.

McClay, A. S., H. L. Hinz, R. A. De Clerck-Floate \& D. P. Peschken (2002b). Matricaria perforata Mérat, Scentless Chamomille (Asteraceae). In: P. G. Mason and J. T. Huber (Eds.) Biological Control Programmes in Canada, 1981-2000. CABI Publishing, Wallingford, Oxon, UK. 395-402.

McFadyen, R. E. (1998). Biological control of weeds. Annual Review of Entomology 43, 369393.

Mills, N. J. (1994). Parasitoid guilds: a comparative analysis of the parasitoid communities of tortricids and weevils. In: B. A. Hawkins and W. Sheehan (Eds.) Parasitoid Community Ecology. Oxford Science Publications. 516pp.

Mitroiu, M. D. (2001). Revision of the Chalcidoidea: Pteromalidae (Hymenoptera) collections of the Belgian Royal Institute of Natural Sciences and the discovery of 31 new species for Belgium. Bulletin de la Société Royale Belge d'Entomologie 137, 91-97.

Noyes, J. S. (2006). Universal Chalcidoidea Database. www.nhm.ac.uk/entomology/chalcidoids/index.html. last accessed 20-April-2006. 
Peschken, D. P. \& A. T. S. Wilkinson (1981). Biocontrol of Canada thistle (Cirsium arvense): releases and effectiveness of Ceutorhynchus litura (Coleoptera: Curculionidae) in Canada. Canadian Entomologist 113, 777-785.

Potter, D. A. \& F. C. Gordon (1985). Parasites associated with the native holly leafminer Phytomyza illicola Loew (Diptera: Agromyzidae) on American holly in Kentucky. Journal of the Kansas Entomological Society 58, 727-730.

Rees, N. E. (1990). Establishment, dispersal, and influence of Ceutorhynchus litura on Canada thistle (Cirsium arvense) in the Gallatin Valley of Montana. Weed Science 38, 198-200.

Schauff, M. E. (1991). The Holarctic genera of Entedoninae (Hymenoptera: Eulophidae). Contributions of the American Entomological Institute 26 (4), 109pp.

Schroeder, D., H. Mueller-Schaerer \& C. S. A. Stinson (1993). A European weed survey in 10 major crop systems to identify targets for biological control. Weed Research 33, 449458.

Skinner, K., L. Smith \& P. Rice (2000). Using noxious weed lists to prioritize targets for developing weed management strategies. Weed Science 48, 640-644.

Stachon, W. J. \& R. L. Zimdahl (1980). Allelopathic activity of Canada thistle (Cirsium arvense) in Colorado. Weed Science 28, 83-86.

Tremblay, E. (1968). Observations on the weevils of hemp (Col., Curculionidae). Morphological and biological notes, and chemical control. Bollettino del Laboratorio di Entomologia Agraria 'Filippo Silvestri', Portici 26, 139-190.

Vidal, S. (1993). Determination list of entomophagous insects No 12. Bulletin Section Regionale Ouest Palaearctique, Organisation Internationale de Lutte Biologique 16 (3), 1-28.

Vidal, S. (1997). Determination list of entomophagous insects. Nr. 13. Bulletin Section Regionale Ouest Palaearctique, Organisation Internationale de Lutte Biologique 20 (2), 1-25.

Vidal, S. (2003). Identification of Hymenopterous parasitoids associated with oilseed rape pests. In: D. V. Alford (Ed.) Biocontrol of Oilseed Rape Pests. Blackwell Science, Oxford.161-179.

Volovnik, S. V. (1994). On parasites and predators of Cleoninae weevils (Col, Curculionidae) in Ukrainian steppe. Journal of Pest Science 67, 77-79.

White, D. J., E. Haber \& C. Keddy (1993). Invasive plants of natural habitats in Canada, Ottawa, Ontario. $121 \mathrm{pp}$. 
Williams, I. H. (2003). Parasitoids of Cabbage Seed Weevil. In: D. V. Alford (Ed.) Biocontrol of Oilseed Rape Pests. Blackwell Science, Oxford. 97-112.

Wittenberg, R. \& M. J. W. Cock (Eds.) (2001). Invasive Alien Species: A Toolkit of Best Prevention and Management Practices. CABI Publishing, Wallingford, Oxon, UK. $228 \mathrm{pp}$.

Woo, S. L., A. G. Thomas, D. P. Peschken, G. G. Bowes, D. W. Douglas, V. L. Harms \& A. S. McClay (1991). The biology of Canadian weeds - Matricaria perforata Mérat (Asteraceae). Canadian Journal of Plant Science 71, 1101-1119.

Yu, D., K. Van Achterberg, K. Horstmann \& J. S. Noyes (2005). Taxapad. Vancouver, BC, Canada.

Zwölfer, H. \& P. Harris (1966). Ceutorhynchus litura (F.) (Col., Curculionidae), a potential insect for the biological control of thistle, Cirsium arvense (L.) Scop., in Canada. Canadian Journal of Zoology 44, 23-38. 


\title{
European Ectoparasitoids of Two Ceutorhynchinae Associated
}

\author{
with Shepherd's Purse and Hoary Cress: Assessing Safety \\ Requirements for Classical Biological Control of Cabbage
}

\section{Seedpod Weevil}

Franck J. Muller ${ }^{1}$, Lloyd M. Dosdall ${ }^{2}$, Peter G. Mason ${ }^{3}$ \& Ulrich Kuhlmann ${ }^{1}$

1- CABI Switzerland Centre, Rue des Grillons 1, 2800 Delémont, Switzerland

2- Department of Agricultural, Food and Nutritional Sciences, University of Alberta, 4-10 Agriculture /

Forestry Centre, Edmonton, Canada

3- Agriculture and Agri-Food Canada, Research Centre, 960 Carling Avenue, Ottawa, Canada

\begin{abstract}
Two Ceutorhynchinae seed feeders (Coleoptera: Curculionidae) Ceutorhynchus typhae (Herbst) [=Ceutorhynchus floralis Paykull] and Ceutorhynchus turbatus (Schultze) are part of the herbivore complex associated with two weeds in Europe, shepherd's purse, Capsella bursa-pastoris (L.) Medicus [Brassicaceae], and hoary cress, Lepidium draba L. (=Cardaria draba) [Asteraceae] respectively. Both weeds of European origin are present in North America and C. turbatus is being considered for introduction as biological control agent against hoary cress, whereas C. typhae is adventive on shepherd's purse. Both weeds occur in the same regions and habitats as the cabbage seedpod weevil, Ceutorhynchus obstrictus (Marsham) [=C. assimilis (Paykull); see Colonnelli (2004)], a major invasive alien pest of canola (Brassica napus L. \& B. rapa L.) in North America. A three year field survey was carried out in Europe to collect C. typhae and C. turbatus and their ectoparasitoids, Trichomalus perfectus Walker and Mesopolobus morys Walker (both Hym: Pteromalidae), with the aim of verifying whether or not the candidate ectoparasitoids considered for introduction as biological control agents against $C$. obstrictus occur in the assemblages associated with these two species. We found no evidence that $T$. perfectus attacks either $C$.
\end{abstract}


typhae or C. turbatus. In contrast, M. morys was found to be the most common parasitoid associated with C. turbatus.

\section{Introduction}

Invasive alien species are recognized as one of the leading threats to biodiversity and they impose enormous costs on agriculture (Wittenberg \& Cock, 2001; Wright et al., 2005). North America has to deal with a number of invasive alien species of high economic importance. Pimentel et al. (2000) state that exotic species are responsible for approximately $\$ 137$ billion in damages per year in the USA. In Canada, annual losses are estimated to be $\$ 4.2$ billion to agriculture alone (Dawson, 2002). Furthermore, invasive species and the ecological and agricultural threats they pose are rapidly increasing with globalization of markets and increased movement of goods and people worldwide (Perrings et al., 2002; Born et al., 2005; Wright et al., 2005). Canada and the USA are currently struggling with a major problem caused by two exotic pest species, one arthropod and one weed, the control measures for which are inextricably linked. The cabbage seedpod weevil, Ceutorhynchus obstrictus (Marsham) [=C. assimilis (Paykull); see Colonnelli (2004)] (Col.: Curculionidae), which is a pest of oilseed rape (canola), Brassica napus L. [Brassicaceae], in Europe was accidentally introduced to North America where it is now widespread (Kuhlmann et al., 2002). Hoary cress, Lepidium draba L. (=Cardaria draba) [Asteraceae], which was accidentally translocated from Europe to North America where it is now a weed mainly in wheat and barley (Schwarzlaender et al., 2002), but also occurs in habitats surrounding canola fields (Cripps et al., in press). Ceutorhynchus obstrictus is currently controlled through the use of broad-spectrum chemical insecticides (Dosdall et al., 2001; Carcamo et al., 2005). Whereas hoary cress is not only growing in crops but is spreading to natural habitats where the application of herbicides would be neither cost-effective nor feasible. Therefore, alternative control strategies are urgently needed to reduce pesticide use and to overcome difficulties in current management strategies.

In comparison with other methods, classical biological control is a very appropriate option to manage invasive alien species (Wittenberg \& Cock, 2001). When it is successful, it is highly cost-effective, permanent, self-sustaining and ecologically safe because of the high specificity of the agents used (Wittenberg \& Cock, 2001). In Europe, the seed-feeding C. 
obstrictus is controlled by a wide range of natural enemies among which are two Pteromalidae species, Trichomalus perfectus (Walker) and Mesopolobus morys (Walker). These parasitoids are known to reduce the populations of $C$. obstrictus by up to $80 \%$ (Williams, 2003) and are being considered for introduction as biological control agents against C. obstrictus in Canada (Kuhlmann et al., 2002). Regarding the potential usage of biological control for hoary cress, the seed-feeder Ceutorhynchus turbatus Schultze (Col.: Curculionidae) is known to be an important natural enemy due to its success at reducing the impact of the weed in its natural habitats in Europe (Cripps et al., in press). Therefore it is undergoing evaluation as a candidate biological control agent against hoary cress and is being considered for introduction to North America (Cripps et al., in press).

It has been reported that hoary cress is a reservoir for economic pests in the USA, such as C. obstrictus (Fox \& Dosdall, 2003; Dosdall \& Moisey, 2004). Cripps et al. (in press) recently confirmed that hoary cress can be used as an alternative food source and/or early season refuge by C. obstrictus. Reducing populations of hoary cress would therefore benefit the C. obstrictus control programme by decreasing the availability of an alternative host plant that helps maintain populations of $C$. obstrictus outside canola fields, away from insecticide treatments. However, potential conflicts could link these two projects. According to Kuhlmann et al. (2006), if T. perfectus and M. morys are introduced for the control of C. obstrictus, the risk of using alternative hosts may be exacerbated if the target and non-targets show an overlap in (1) geographical distribution; (2) time of occurrence; and (3) host feeding niches. These conditions might be combined in the case of both C. turbatus and C. obstrictus. Interestingly, these overlaps might also apply to another non-target weevil as well, Ceutorhynchus typhae (Herbst) [=Ceutorhynchus floralis Paykull] (Col.: Curculionidae), which shares the same feeding niche and habitats. This seed-feeder is present in Canada (Bousquet, 1991; Bouchard et al., 2005) and is part of the herbivore complex associated with shepherd's purse Capsella bursa-pastoris (L.) Medicus [Brassicaceae], a weed of economic importance in canola, wheat and barley in North America (Moss, 1959; Budd \& Best, 1969; Leeson et al., 2005). Consequently, these interactions must be taken into consideration when assessing potential non-target effects of biological control agents of $C$. obstrictus.

Prior to introduction, the potential risks of $C$. obstrictus parasitoids attacking related non-target species have to be assessed; therefore surveys in the area of origin are necessary to determine the parasitoid assemblages associated with C. turbatus and C. typhae. Furthermore, such studies will provide information on ecological traits of the weevils that is crucial when selecting non-target species for host-specificity testing, allowing more precise prediction of 
potential risks associated with introduction of candidate agents for biological control of $C$. obstrictus in Canada. The objectives of this study were to: 1) describe the phenology of $C$. typhae and C. turbatus to determine if there is a phenological overlap with that of $C$. obstrictus; 2) assess the parasitism levels of C. typhae and C. turbatus, particularly by ectoparasitoids; and 3) determine the parasitoid assemblage associated with these two Ceutorhynchinae species.

\section{Material \& Methods}

\section{Field collected material}

All shepherd's purse and hoary cress plants studied were field collected in fallow fields, at field margins or along road sides in May to June in 2003 and 2004. Surveys for C. typhae were made at seven sites in Germany, Switzerland and France and for C. turbatus at fourteen sites located in Switzerland and two separate regions of Hungary (Figure 1). Because shepherd's purse and hoary cress are pioneer species, they are very often growing at road sides or field margins. Therefore it is difficult to find stable sites as these are regularly mowed. However, it is clear that C. typhae and C. turbatus occur more frequently in stable sites where they have had time to build up populations. Thus, collections were made in wastelands or abandoned fields because they represented more stable habitats.

\section{Phenology of Ceutorhynchinae hosts}

Samples of 10 to 20 host plants were collected and dissected as often as every two days and at a maximum of 10 day-intervals. Twenty pods per plant were dissected to detect Ceutorhynchinae eggs and larvae which were determined to instar. The late third instar larvae of both C. typhae and C. turbatus chew an exit hole through the pod wall and drop down into the soil where they pupate. Thus, exit holes were recorded and taken into account to estimate the number of healthy third instar larvae that had left the plants. At high larval infestation levels, a maximum of two larvae can develop inside the same pod, feeding on the seeds separated by an internal wall. Thus, two third instar larvae can exit the plant using the same hole, which might have led to a slight under-estimation of larval numbers. 


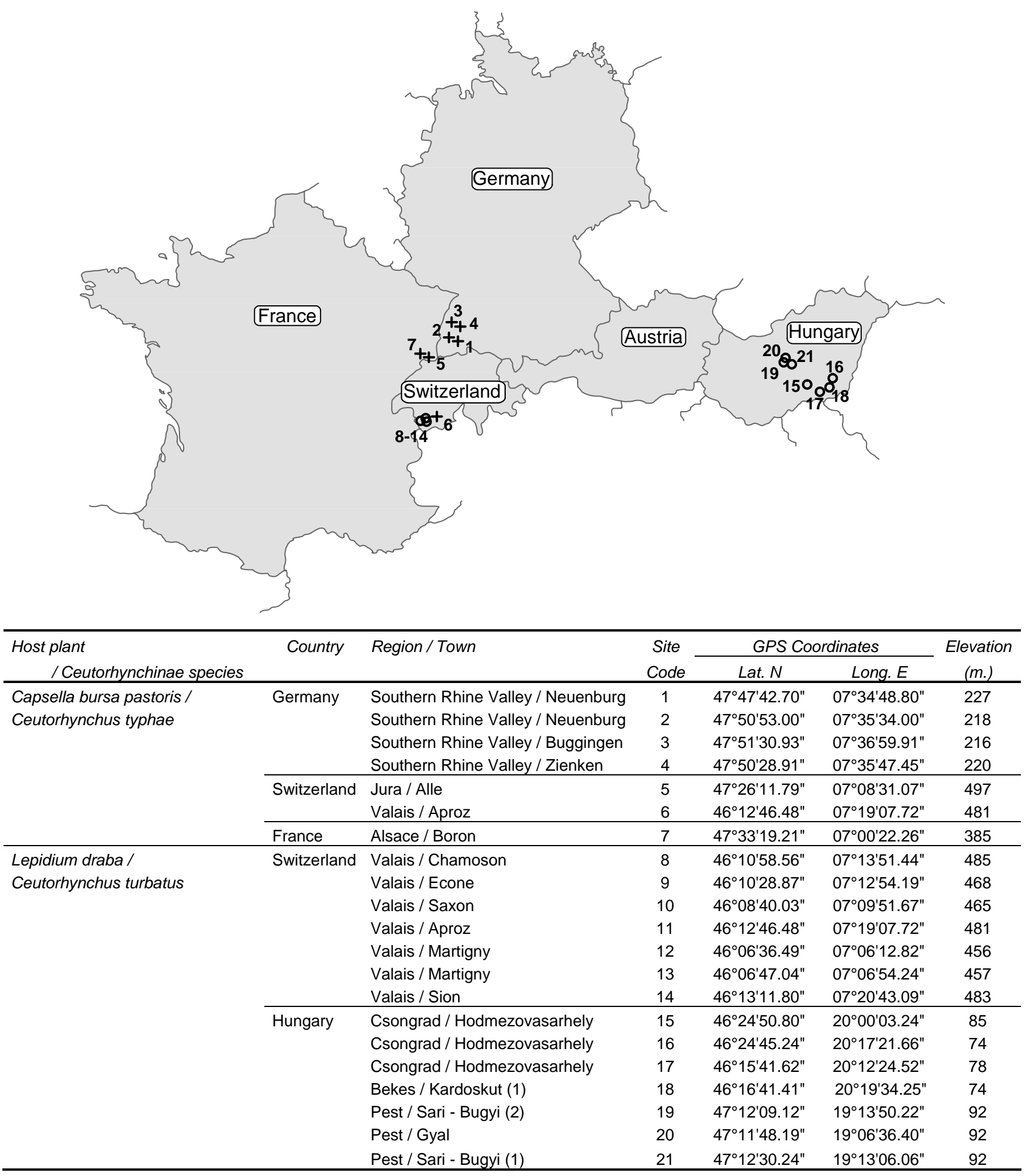

Figure 1. Location of field collection sites of Capsella bursa-pastoris (L.) Medicus surveyed for the occurrence of Ceutorhynchus typhae (Herbst) [o] and Lepidium draba L. for Ceutorhynchus turbatus Schultze [+] in 2003 and 2004, respectively. 


\section{Parasitism by ectoparasitoids}

For each plant dissected, ectoparasitoid eggs and larvae found on host larvae as well as ectoparasitoid pupae found near the remains of a consumed host body were recorded to estimate the parasitism level on each collection date for every field site studied. Mortality due to host feeding by ectoparasitoid adults was considered as an indirect effect of parasitism and recorded independently. Parasitism was calculated for each site as follows:

$$
\% \text { Parasitism }=\frac{\sum_{1}^{n} \text { paras. }}{\sum_{1}^{n} \text { avail.hosts }} \times 100=\frac{\sum_{\text {larv }}^{\text {par }}+\sum_{\text {larv }}^{\dagger}+\sum_{\text {par }}{ }^{\text {alone }}}{\sum_{\text {larv }}^{\text {healthy }}+\sum_{\text {larv }}{ }^{\text {par }}+\sum_{\text {larv }}^{\dagger}+\sum_{\text {holes }}+\sum_{\text {par }} \text { alone }} \times 100
$$

Where $\sum_{1}^{n}$ paras. is the total number of parasitoids found in the plant; $\sum_{1}^{n}$ avail.hosts is the total number of hosts available for parasitism (second and third instar larvae) found in the plant; $\Sigma_{\text {larv }}^{p a r}$ is the number of larvae found parasitized by an ectoparasitoid; $\Sigma_{\text {larv }}^{\dagger}$ is the number of larvae found dead with traces of host feeding like brownish punctures on the tegumen; $\Sigma_{\text {par }}$ alone is the number of parasitoids found alone near the remains of a consumed host, either as a pupa, or as a newly emerged adult which had not yet exited the plant; $\Sigma_{\text {larv }}$ healthy is the number of healthy host larvae; $\Sigma_{\text {hole }}$ is the number of exit holes (made by healthy third instar larvae that have left the plant), found on the shoots or pods during dissections.

A representative parasitism level was estimated for each site, that date on which the maximum number of healthy larvae still available for parasitism were present in the plant, i.e. just before exit holes appeared.

Host density was determined by considering the maximum number of hosts parasitized or available for parasitism during the season. Thus, only second and third instar larvae were used for calculation. Exit holes were recorded as equivalent to a single third instar larvae that had exited the plant, although as explained previously two larvae can exit from the same hole.

\section{Parasitoid assemblages}

Parasitoid eggs and larvae were reared on the host larvae they had been parasitizing and pupae were individually reared on a disc of filter paper in $5.5 \mathrm{~cm}$ diameter Petri dishes. Insects were maintained in a climate chamber at $20 \pm 2^{\circ} \mathrm{C}, 70 \% \pm 10 \mathrm{RH}$. and $16 \mathrm{~h} \mathrm{~L}$ : $8 \mathrm{~h}$ D. The insects were checked daily until emergence of the adult parasitoid. Some groups emerged the same summer season that they were collected. Mortality was rather high over rearing periods. 
Identification was possible only for adults which, directly after they had emerged, were killed using Ethyl Acetate. Every specimen was card-mounted, labelled with individual information, and stored for further identification purposes. All taxonomic identifications for the family Pteromalidae were made in collaboration with Hannes Baur at the Natural History Museum of Bern (NMBE), Switzerland and Dr. Gary Gibson, Canadian National Collection of Insects, Ottawa, Canada. Eurytomidae specimens were identified by Michael Gates, USDA-ARS, National Museum of Natural History, Washington DC, United States. Where possible, Pteromalidae and Braconidae specimens were identified to species while other families were identified to genus.

Available information on life cycle, primary host association, hyperparasitism records, if existing, and plant host - weevil - parasitoid associations were obtained from the literature. Relevant references were obtained from the Taxapad programme (Yu et al., 2005) and the Universal Chalcidoidea Database (Noyes, 2006). Hannes Baur, NMBE, Switzerland, and Garry Gibson, CNC, Ottawa, Canada were consulted for providing additional information on Chalcidoidea.

\section{Results}

\section{Ceutorhynchus typhae on shepherd's purse}

\section{Phenology of hosts}

Sites surveyed in Germany, France and Switzerland yielded similar results in both 2003 and 2004 (Figure 2). Ceutorhynchus typhae laid eggs during the entire sampling period. First instar larvae were present in pods of Shepherd's purse from mid-may onwards. The number of second and third instar larvae available to parasitoids increased beginning the second week of May and in Germany, Southern Rhine Valley, reached maximum densities of between $0.2 \pm 0.1$ (Site 4) and 3.1 \pm 0.4 (Site 1) per plant (Table 1) on the second and third weeks of June. At all sites surveyed, third instar larvae appeared beginning the first week of May and mature larvae started to leave the plants, beginning the second week of June. 


\section{$\underline{\text { Phenology of ectoparasitoids }}$}

Ectoparasitoids were present beginning the first week of June and for a period of about two weeks (Figure 3) Overall parasitism was highest at Site 2 near Neuenburg, southern Rhine Valley, Germany. Parasitism reached a maximum of 59.5\% at Site 5 near Alle, in the Swiss Jura on the 28 June 2004. Parasitism levels were between 10 and 15\% in Germany (2003) and between 15 and 59.5\% in Switzerland and France (2004).

Table 1. Mean number $( \pm \mathrm{SE})$ of second and third instar larvae of Ceutorhynchus typhae (Herbst) available for parasitism, and percent parasitism observed in Germany, Switzerland and France in 2003 and 2004 .

\begin{tabular}{|c|c|c|c|c|c|c|}
\hline \multicolumn{2}{|r|}{ Location } & \multirow{3}{*}{$\begin{array}{c}\text { Site } \\
\text { Code }\end{array}$} & \multirow{2}{*}{\multicolumn{3}{|c|}{$\begin{array}{c}\text { Mean \# ( } \pm S E) \text { of } \\
\text { Hosts } \\
\text { (L2/L3) per plant }\end{array}$}} & \multirow{3}{*}{$\begin{array}{c}\% \\
\text { parasitisim } \\
10.0\end{array}$} \\
\hline \multirow{5}{*}{ Germany } & & & & & & \\
\hline & Southern Rhine Valley / Neuenburg & & 1.58 & \pm & 0.45 & \\
\hline & Southern Rhine Valley / Neuenburg & 2 & 3.05 & \pm & 0.44 & 11.5 \\
\hline & Southern Rhine Valley / Buggingen & 3 & 0.00 & \pm & & 0.0 \\
\hline & Southern Rhine Valley / Zienken & 4 & 0.15 & \pm & 0.08 & 0.0 \\
\hline \multirow[t]{2}{*}{ Switzerland } & Jura / Alle & 5 & 4.60 & \pm & 0.29 & 59.5 \\
\hline & Valais / Aproz & 6 & 1.85 & \pm & 0.33 & 15.0 \\
\hline France & Alsace / Boron & 7 & 1.85 & \pm & 0.15 & 16.7 \\
\hline
\end{tabular}

The relationship between host density and parasitism was significant (ANOVA, $\mathrm{F}=18.45$; $\mathrm{df}$ 1,$6 ; \mathrm{P}=0.028 ; \mathrm{y}=11.22 \mathrm{x}-4.8645 ; \mathrm{R}^{2}=0.7868$ ) showing the number of $C$. typhae larvae available to parasitism in the plants was positively related to the level of parasitism by ectoparasitoids (Figure 2).

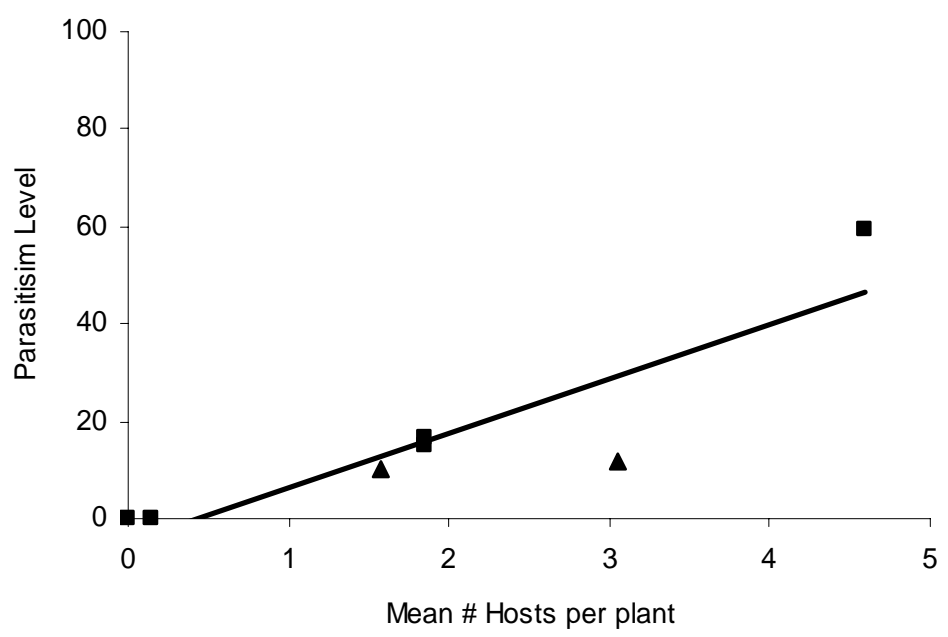

Figure 2. Comparison between mean number of hosts and percentage parasitism observed 2003 and $2004(\bullet)$ surveys. (ANOVA, $\mathrm{F}=18.45 ; \mathrm{df1}, 6 ; \mathrm{P}=0.028 ; \mathrm{y}=11.22 \mathrm{x}-4.8645 ; \mathrm{R}^{2}=0.7868$ ). 
Germany - Southern Rhine Valley - Site \#1
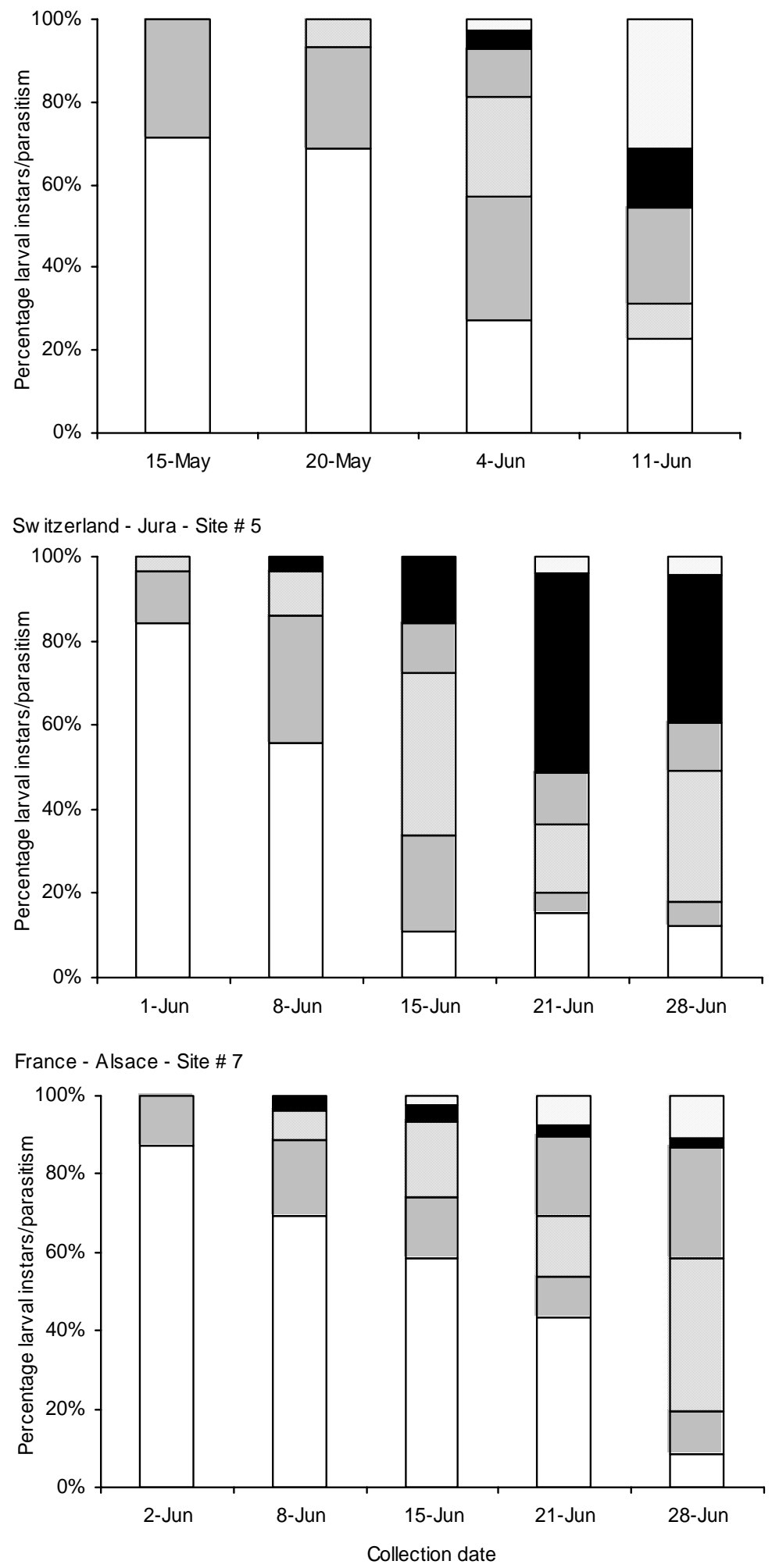

口Eggs $\square$ L1 $\square$ L2 $\square$ L3 $\square$ Parasitoids $\square$ Exit Holes

Figure 3. Proportion of eggs, larval instars 1-3 of Ceutorhynchus typhae (Herbst), parasitism, and exit holes in Germany/Southern Rhine Valley, Neueunburg (Site 1), Switzerland/ Jura, Alle (Site 5), and France/ Alsace, Boron (Site 7) between May and July in 2003 and 2004. 


\section{Parasitoid assemblages}

Two parasitoid species associated with C. typhae were collected from shepherd's purse, both belonged to the family Pteromalidae (Hymenoptera). This assemblage included one new species belonging to the genus Mesopolobus, Mesopolobus gemellus Baur\&Muller sp. nov. (Baur et al., submitted; Chapter II of the thesis) of which 37 specimens were individually reared (Table 3). Only a single specimen of S. gracilis was found at the Site 6 near Aproz in the Swiss Valais.

Mesopolobus gemellus Baur\&Muller sp. nov. (Pteromalidae):

Life cycle: Results of our study show that Mesopolobus gemellus females lay eggs on late instar larvae of C. typhae in May and June. Adults of the new generation emerge in June and July the same year, and exit the senesced pods (Baur et al., submitted; Chapter II of the thesis).

Primary host association: Mesopolobus gemellus is known only from C. typhae. However, the species has only very recently been discovered, and since it is closely related to and might have been misidentified as $M$. morys in the past, other primary host associations may exist that will be clarified in the future.

Plant association: The species has only been collected from pods of shepherd's purse (Baur et al., submitted; Chapter II of the thesis).

Stenomalina gracilis Walker (Pteromalidae):

Life cycle: Stenomalina spp. are solitary primary larval or pupal ectoparasitoids. Adults can be observed in the field from June to October (Graham, 1969).

Primary host association: Stenomalina gracilis is associated with weevil species in the subfamily Ceutorhynchinae, such as C. obstrictus (Dmoch, 1975a), H. litura (Vidal, 1997), C. napi Gyllenhal, C. pallidactlylus (Marsham), and C. roberti Gyllenhal (Kuhlmann \& Mason, 2002). In this study, S. gracilis was associated with C. turbatus. Other known hosts of $S$. gracilis include Diptera (Agromyzidae, Calliphoridae, Cecidomyiidae and Chloropidae, Tephritidae), Hymenoptera (Cynipidae) and Lepidoptera (Tortricidae) (Noyes, 2006).

Plant association: Stenomalina gracilis has been associated with hosts developing on other Asteraceae, Brassicaceae, Cupressaceae and Fagaceae (Noyes, 2006) . 


\section{Ceutorhynchus turbatus on hoary cress}

\section{Phenology of hosts}

Only eggs of C. turbatus were found on the first sampling dates on 20 and 26 May in 2004 (Figure 5) Eggs hatched and first instar larvae were observed beginning the last week of May or first week of June. Second instar larvae were present beginning the second week of June at all sites surveyed in Switzerland and Hungary. Infestation levels observed in Valais Switzerland were rather similar in 2003 and 2004, with maximum densities of second and third instar larvae per plant observed at 9.3 \pm 0.2 (Site 10) near Saxon in 2003 and 11.3 \pm 0.6 near Sion (Site 14) in 2004 (Table 2). In Hungary, in 2004, densities tended to be lower on average at all sites surveyed in Hungary in 2004, with a maximum of $7.5 \pm 0.7$ second and third instar larvae per plant observed at the Site 17 near Hödmezövasarhely (Table 2). On average, densities of second and third instar larvae per plant determined in 2003 and 2004 were $6.8 \pm 1.7$ in Switzerland, and $2.1 \pm 1.6$ in Hungary.

Table 2. Mean number $( \pm \mathrm{SE})$ of second and third instar larvae of Ceutorhynchus turbatus Schultze available for parasitism, and percent parasitism observed in Switerland and Hungary in 2003 and 2004.

\begin{tabular}{|c|c|c|c|c|c|c|}
\hline \multicolumn{2}{|r|}{ Location } & \multirow{2}{*}{$\begin{array}{c}\begin{array}{c}\text { Site } \\
\text { Code }\end{array} \\
8\end{array}$} & \multicolumn{3}{|c|}{$\begin{array}{c}\text { Mean \# ( } \pm S E) \text { of hosts } \\
(L 2 / L 3) \text { per plant }\end{array}$} & \multirow{2}{*}{$\begin{array}{c}\% \\
\text { Parasitisim } \\
15.4\end{array}$} \\
\hline \multirow[t]{7}{*}{ Switzerland } & Valais / Chamoson & & 3.90 & & * & \\
\hline & Valais / Econe & 9 & 1.88 & & * & 80.0 \\
\hline & Valais / Saxon & 10 & 9.15 & \pm & 0.21 & 39.8 \\
\hline & Valais / Aproz & 11 & 0.75 & \pm & 0.23 & 18.2 \\
\hline & Valais / Martigny & 12 & 10.50 & \pm & 0.72 & 19.9 \\
\hline & Valais / Martigny & 13 & 10.10 & \pm & 1.02 & 32.8 \\
\hline & Valais / Sion & 14 & 11.25 & \pm & 0.64 & 44.0 \\
\hline \multirow[t]{7}{*}{ Hungary } & Csongrad / Hodmezovasarhely & 15 & 7.50 & \pm & 0.70 & 25.6 \\
\hline & Csongrad / Hodmezovasarhely & 16 & 0.00 & \pm & 0.00 & 0.0 \\
\hline & Csongrad / Hodmezovasarhely & 17 & 3.35 & \pm & 0.40 & 41.8 \\
\hline & Bekes / Kardoskut (1) & 18 & 1.15 & \pm & 0.27 & 28.6 \\
\hline & Pest / Sari - Bugyi (2) & 19 & 1.15 & \pm & 0.31 & 33.3 \\
\hline & Pest / Gyal & 20 & 0.90 & \pm & 0.26 & 11.1 \\
\hline & Pest / Sari - Bugyi (1) & 21 & 0.70 & \pm & 0.21 & 21.4 \\
\hline
\end{tabular}

* only one sampling date

\section{Phenology of ectoparasitoids}

At all sites, parasitoids were present earlier in the season in Hungary than in Switzerland at all sites surveyed. First evidence of parasitism occurred the second week of June in Hungary, as 
soon as second instar larvae were observed, whereas in the Swiss Valais, parasitism was evident later, beginning the last week of June (Figure 5). All healthy larvae had left the plants on the 24 June in Hungary at the Site 20 near Gyal, whereas at the same period all larval instars were observed in the plants dissected from sites surveyed in Switzerland (Figure 5). Parasitism levels in Switzerland ranged between 15.4 to $80 \%$ in 2003 , and 18.2 to $44 \%$ in 2004. Similar parasitism levels (11.1 to 41.8\%) were observed in Hungary, except for Site 18 near Hödmezövasarhely where no parasitoids were found. The relationship between number of C. turbatus larvae available for parasitism in the plants and level of parasitism was not significant (ANOVA, $F=0,5359 ;$ df 1,$6 ; \quad \mathrm{P}=0.09 ; \mathrm{y}=0.9274 \mathrm{x}+25.296 ; \mathrm{R}^{2}=0.0427$ ) (Figure 4).

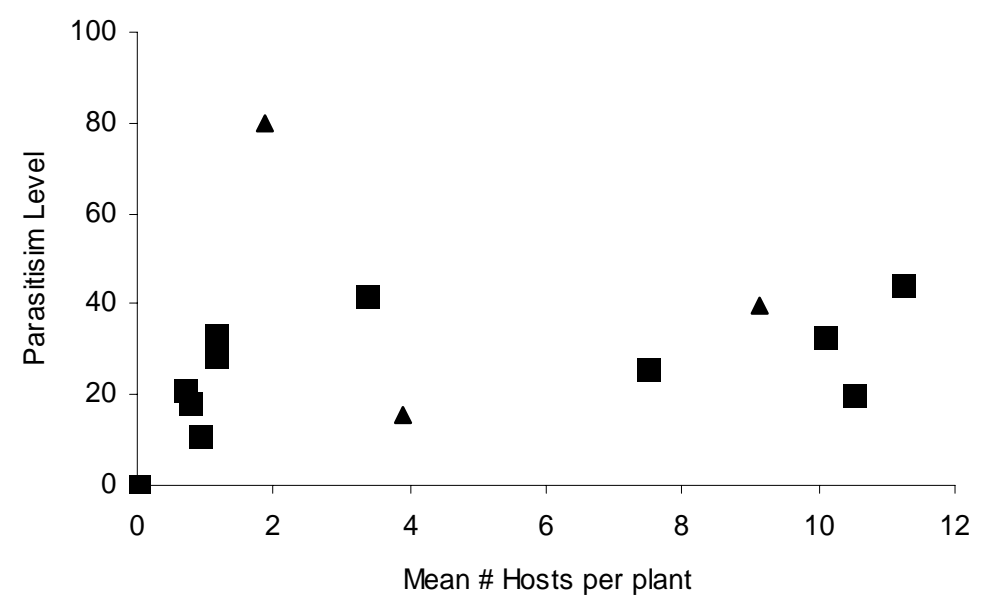

Figure 4. Comparison between mean number of hosts and percentage parasitism observed $2003(\boldsymbol{\Delta})$ and $2004(\bullet)$ surveys. (ANOVA, $\mathrm{F}=0.5359 ; \mathrm{df} 1,6 ; \mathrm{P}=0.09 ; \mathrm{y}=0.9274 \mathrm{x}+$ 25.296; $\left.\mathrm{R}^{2}=0.0427\right)$

\section{Parasitoid assemblage}

The ten parasitoid species associated with C. turbatus from hoary cress belonged to the hymenopteran families: Pteromalidae, Eulophidae, Eurytomidae, and Eupelmidae (Table 3). Of the species found some are poorly known and taxonomic expertise is not available. Available information such as life cycle, primary host association and hyperparasitism, and plant association are provided for all members of the parasitoid assemblage of C. turbatus in alphabetic order: 
Baryscapus sp. (Eulophidae):

Life cycle: Baryscapus sp. belong to the Tetrastichinae, which are usually primary endoparasitoids of the eggs, larvae or pupae of gallicolous Diptera, Hymenoptera or Lepidoptera (Noyes, 2006). A number of species develop as ectoparasitoids or as facultative or obligate hyperparasitoids. Others are predators on the eggs of various insects. Although little is known of the biology of Baryscapus species, many different life styles seem to occur among the genus: some species are primary ectoparasitoids of Aranea eggs (Noyes, 2006),
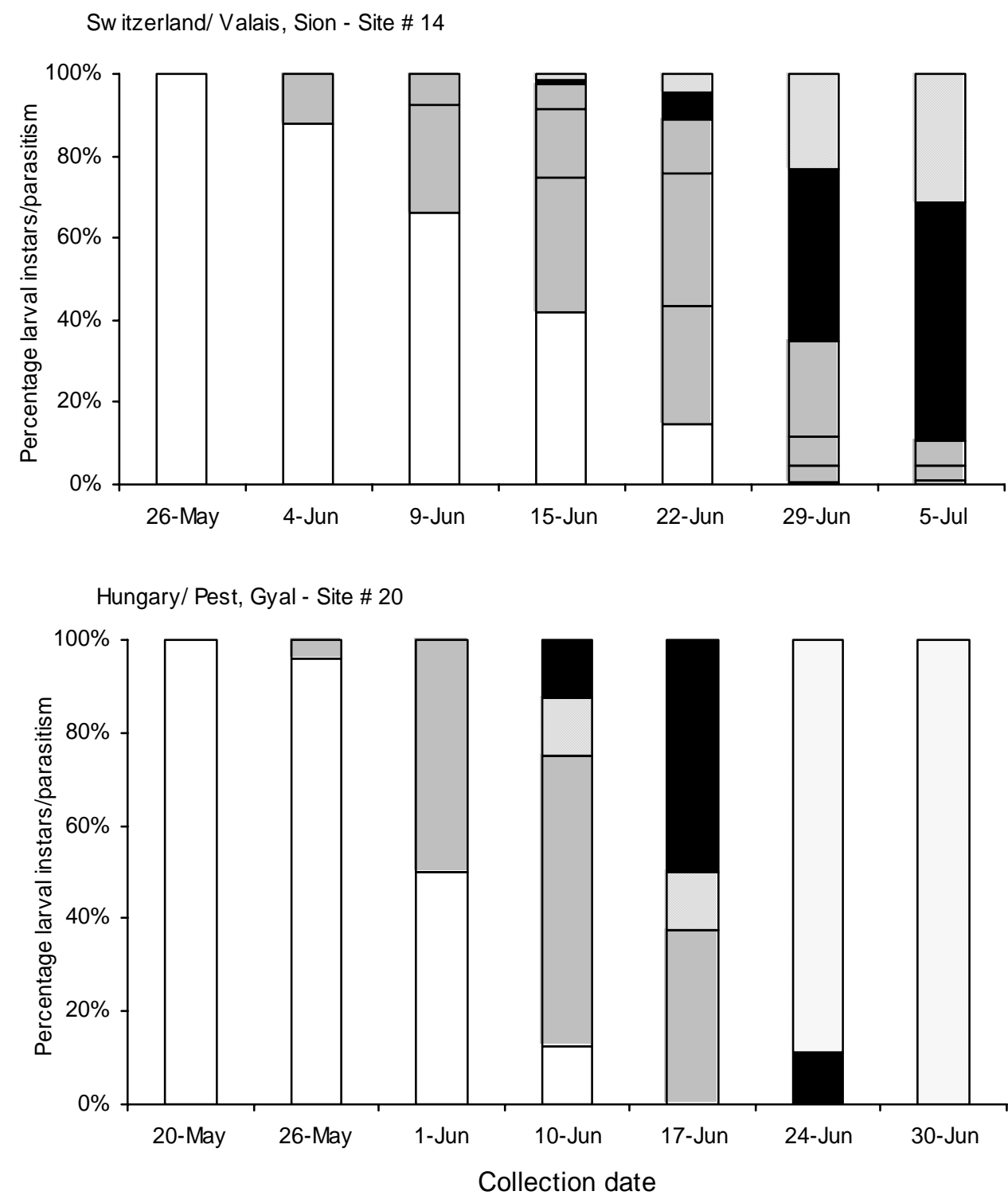

口Eggs $\square$ L1 $\square$ L2 $\square$ L3 $\square$ Parasitoids $\square$ Exit Holes

Figure 5. Proportion of eggs, larval instars 1-3 of Ceutorhynchus turbatus Schultze, parasitism, and exit holes in Switzerland/ Valais, Sion (Site 14) and Hungary/ Pest, Gyal (Site 20) between May and July in 2004. 
others are pupal endoparasitoids and overwinter in the coccons of their hosts (Mey, 1993). In our study specimens were found that were larval ectoparasitoids of $C$. turbatus in pods of shepherd's purse.

Primary host association: Species of Baryscapus are associated with hosts among Coleoptera, Diptera (Agromyzidae), Lepidoptera (Gracillariidae, Lyonetiidae, Notodontidae, Tischeriidae, Tortricidae and Yponomeutidae), Neuroptera (Chrysopidae), and Aranea (Tomisidae) (Noyes, 2006).

Plant association: Baryscapus sp. hosts develop in plant species of Brassicaceae, Fagaceae, Hippocastanaceae, Pinaceae, Rutaceae, Salicaceae, Verbenaceae (Noyes, 2006).

Closterocerus spp. (Eulophidae):

Species of the genus Closterocerus have a broad host range (Hansson, 1990; Hansson, 1994; Gumovski, 2001; Yu et al., 2005). Some species are known to be primary parasitoids of leaf-miners and gall-formers, and others are also reported from Symphyta eggs (Argidae, Diprionidae), armored scales (Daspididae), and psyllids (Psyllidae) (Schauff, 1991; Hansson, 1996; Yu et al., 2005).

Eupelmus sp. (Eupelmidae):

The majority of Eupelmidae species are parasitoids and facultative hyperparasitoids on the immature stages of Lepidoptera, Homoptera, Hymenoptera, Coleoptera, Neuroptera and Orthoptera (Clausen, 1940; Noyes, 2006). A small number of species are predators on the eggs or larvae of various insects, or on the eggs of spiders and a few are solitary, primary endoparasitoids of eggs of Lepidoptera, Orthoptera and Hemiptera (Yu et al., 2005). Most eupelmids are solitary, but some species are gregarious (Clausen, 1940). Most are ectoparasitoids, including some that develop gregariously on dipterous pupae within puparia, and a few species are solitary endoparasitoids of Coccoidea (Noyes, 2006).

Eurytoma curculionum Mayr (Eurytomidae):

Life cycle: Eurytoma curculionum is a larval ectoparasitoid of concealed Coleoptera (Fischer, 1965). Less frequently it is a hyperparasitoid of late instar larvae of chalcid wasps (Fischer, 1965). Eurytoma curculionum is bivoltine, adults emerge in late May and June, a partial second generation occurs in August (Fischer, 1965).

Primary host association: Eurytoma curculionum is associated with Coleoptera such as Apionidae (Fischer, 1965; Vidal, 1997), Buprestidae (Boucek, 1977) and Curculionidae 
(Dmoch, 1975a; Boucek, 1977). In this study, E. curculionum was for the first time associated with C. turbatus.

Plant association: Records can be found of E. curculionum associated with hosts developing in Brassicaceae, Polygonaceae, Rubiaceae and Scrophulariaceae (Yu et al., 2005).

Mesopolobus morys Walker (Pteromalidae):

Life cycle: Although some aspects of its biology, such as overwintering, still remain relatively obscure, the biology of the species has been well documented. M. morys is a solitary larval ectoparasitoid of concealed hosts (Bonnemaison, 1957; Dmoch, 1975b; Dmoch, 1975a; Buechi, 1993; Murchie \& Williams, 1998). Females lay their eggs in spring and adults of the new generation emerge during the same season (Dmoch \& Klimek, 1975). The new generation adults overwinter and are active again the following spring. The species completes a single generation per year, however, a partial second generation may occur when conditions are optimal (Muller et al., 2003; Muller et al., 2004).

Primary host association: The species has a host range that includes Coleoptera (Apionidae, Curculionidae) and Diptera (Cecidomyiidae) (Graham, 1969; Noyes, 2006).

Plant association: Insect hosts that allow complete development of the species are associated with plants of the families Brassicaceae, Fabaceae and Tamaricaceae (Noyes, 2006).

Pteromalus sequester Walker (Pteromalidae):

Life cycle: Female $P$. sequester lay eggs externally on the larvae or pupae of their hosts, adults of the new generation generally overwinter in their host's food plants (Parnell, 1964).

Primary host association and hyperparasitism: Most of the known hosts of $P$. sequester are concealed and include Coleoptera (Apionidae, Bruchidae, Curculionidae), Diptera (Cecidomyiidae), Hymenoptera (Eurytomidae) and Lepidoptera (Pyralidae). A few records documented $P$. sequester as a hyperparasitoid of Hymenoptera such as species of Pergidae (Noyes, 2006).

Plant association: Pteromalus sequester is associated with insect hosts that develop in a wide range of plant species of the Asteraceae, Caryophyllaceae, Chenopodiaceae, Convolvulaceae, Cupressaceae, Euphorbiaceae, Fabaceae, Malvaceae, Plantaginaceae, Scrophulariaceae, Tamaricaceae and Zygophyllaceae (Noyes, 2006). 
Pteromalus sp. (Pteromalidae):

Life cycle: Pteromalus species have a wide range of life styles, being either solitary or gregarious, larval or pupal, ecto- or endoparasitoid (Noyes, 2006). Some species such as Pteromalus puparum (Linnaeus) overwinter as mature larvae within their host's pupae (Takagi, 1985).

Primary host association: Species of Pteromalus are associated with hosts in a wide range of families among Coleoptera, Dictyoptera, Diptera, Hemiptera, Hymenoptera and Lepidoptera (Noyes, 2006). In addition, Noyes (2006) listed several species that are known to develop as hyperparastioids of Diptera (Tachinidae), Hymenoptera (Braconidae, Chalcididae, Encyrtidae, Eulophidae, Ichneumonidae). In our study, individuals of Baryscapus sp. were found as ectoparasitoids of larval C. turbatus.

Plant association: As a consequence of the wide range of known hosts, the species of Pteromalus develop in association with a broad variety of plants among Anacardiaceae, Asteraceae, Betulaceae, Boraginaceae, Brassicaceae, Cyperaceae, Ericaceae, Fabaceae, Fagaceae, Hippocastanaceae, Malvaceae, Oleaceae, Onagraceae, Pedaliaceae, Pinaceae, Poaceae, Rosaceae, Rutaceae, Salicaceae, Scrophulariaceae, Tamaricaceae, Tyhpaceae, Ulmaceae, Urticaceae (Noyes, 2006).

Syntomopus sp. (Pteromalidae):

Life cycle: Syntomopus spp. are primary pupal ectoparasitoids (Graham, 1969). Results obtained in this study indicate that Syntomopus sp. is a primary larval ectoparasitoid. Adults appear in the field in May and July-August, and there are probably two generations per year (Graham, 1969).

Primary host association: Hosts of Syntomopus sp. include Diptera (Agromyzidae) and Lepidoptera (Pterophoridae) (Yu et al., 2005). The records from this study indicate that Syntomopus sp. is an ectoparasitoid of C. turbatus.

Plant association: Whereas other hosts of Syntomopus spp. are known to develop in hosts associated with Asteraceae, Apiaceae, Fabaceae, Solanaceae and Urticaceae (Graham, 1969; Vidal, 1993; Andriescu \& Mitroiu, 2001). Recorded here is the first association of a Syntomopus sp. from a host feeding on hoary cress, hoary cress. 
Trichomalus cf. perfectus Walker (Pteromalidae):

Note: Identifications of $T$. cf perfectus was difficult to confirm because only two specimens were collected and a series of each species is needed to study variations in several morphological characters that differentiate the species.

Life cycle: The related species, Trichomalus perfectus, is a solitary larval ectoparasitoid (Bonnemaison, 1957), in spring adults fly away from their overwintering sites in forest habitats (Szczepanski, 1972; Dmoch \& Klimek, 1975) and are active from May until August (Graham, 1969). Trichomalus perfectus, completes only one generation per year (Dmoch, 1975a; Dmoch, 1975b; Dmoch \& Klimek, 1975), however, a possible partial second generation may occur if acceptable hosts (e.g., C. obstrictus on summer canola) are present later in the season (Graham, 1969).

Primary host association: Trichomalus perfectus, is restricted to species of Ceutorhynchinae (Coleoptera) (Noyes, 2006). However, there are a few records of T. perfectus being reared from Diptera (Cecidomyiidae) (Vidal, 1993) and Hymenoptera (Torymidae) (Mitroiu, 2001). Plant association: Trichomalus perfectus is associated with hosts that develop in Asteraceae, Brassicaceae, Cupressaceae, Poaceae and Resedaceae (Dmoch, 1975a; Vidal, 1997; Kuhlmann \& Mason, 2002).

Trichomalus sp. (Pteromalidae):

Life cycle: Trichomalus species are all thought to be larval ectoparasitoids (Graham, 1969). Except for certain species involved in biological control programmes such as T. perfectus (see above), the biology of the genus is mostly unknown. Adults can be observed flying from May to September. In most species females overwinter in dry places such as amongst the foliage of coniferous trees (Graham, 1969).

Primary host association and hyperparasitism: Trichomalus spp. are associated with primary hosts of Coleoptera (Apionidae, Buprestidae, Chrysomelidae, Curculionidae), Diptera (Cecidomyiidae, Ephydridae), Hymenoptera (Cynipidae Diprionidae Tenthredinidae Torymidae) and Lepidoptera (Lyonetiidae, Yponomeutidae) (Graham, 1969; Noyes, 2006). In addition, records have been made of species of Trichomalus associated with parasitoid hosts among Diptera (Tachinidae) and Hymenoptera (Braconidae, Ichneumonidae) (Noyes, 2006). Plant association: Species of the genus Trichomalus are known to be associated with hosts that develop in plants among the families Asteraceae, Brassicaceae, Cupressaceae, Poaceae, Resedaceae and Rosaceae (Graham, 1969; Dmoch, 1975a; Vidal, 1997; Kuhlmann \& Mason, 2002; Noyes, 2006). 
Table 3. Species and their proportion of the parasitoid assemblage of parasitoids associated with Ceutorhynchus turbatus (Schultze) for each sample site in 2003 and 2004.

\begin{tabular}{|c|c|c|c|c|}
\hline Year & Site & Parasitoid Species & \# Individuals & $\%$ \\
\hline \multirow[t]{5}{*}{2003} & Switzerland/ Valais - Site 10 & Mesopolobus morys Walker ${ }^{1}$ & 34 & 100.0 \\
\hline & \multirow[t]{2}{*}{ Switzerland/ Valais - Site 9} & Mesopolobus morys Walker $^{1}$ & 2 & 66.7 \\
\hline & & Pteromalus sequester Walker gr. ${ }^{1}$ & 1 & 33.3 \\
\hline & \multirow[t]{2}{*}{ Switzerland/ Valais - Site 14} & Mesopolobus morys Walker ${ }^{1}$ & 4 & 57.1 \\
\hline & & Pteromalus sequester Walker gr. ${ }^{1}$ & 3 & 42.9 \\
\hline \multirow[t]{39}{*}{2004} & Switzerland/Valais - Site 11 & Pteromalus sequester Walker gr. $^{1}$ & 2 & 100.0 \\
\hline & \multirow[t]{2}{*}{ Switzerland/Valais - Site 12} & Mesopolobus morys Walker ${ }^{1}$ & 13 & 86.7 \\
\hline & & Pteromalus sequester Walker gr. ${ }^{1}$ & 2 & 13.3 \\
\hline & \multirow[t]{2}{*}{ Switzerland/Valais - Site 13} & Pteromalus sequester Walker gr. $^{1}$ & 20 & 52.6 \\
\hline & & Mesopolobus morys Walker ${ }^{1}$ & 18 & 47.4 \\
\hline & \multirow[t]{3}{*}{ Switzerland/Valais - Site 14} & Pteromalus sequester Walker gr. $^{1}$ & 27 & 55.1 \\
\hline & & Mesopolobus morys Walker ${ }^{1}$ & 21 & 42.9 \\
\hline & & Eupelmus sp. ${ }^{4}$ & 1 & 2.0 \\
\hline & \multirow[t]{4}{*}{ Hungary/Csongrad - Site 15} & Mesopolobus morys Walker ${ }^{1}$ & 14 & 50.0 \\
\hline & & Pteromalus sequester Walker gr. ${ }^{1}$ & 11 & 39.2 \\
\hline & & Baryscapus sp. ${ }^{2}$ & 2 & 7.2 \\
\hline & & Eupelmus sp. ${ }^{4}$ & 1 & 3.6 \\
\hline & \multirow{2}{*}{ Hungary/Csongrad - Site 16} & Baryscapus sp. $^{2}$ & 1 & 50.0 \\
\hline & & Pteromalus sequester Walker gr. ${ }^{1}$ & 1 & 50.0 \\
\hline & \multirow[t]{11}{*}{ Hungary/Csongrad - Site 17} & Pteromalus sequester Walker gr. ${ }^{1}$ & 20 & 29.4 \\
\hline & & Closterocerus sp. $^{2}$ & 13 & 19.1 \\
\hline & & Baryscapus sp. $^{2}$ & 10 & 14.7 \\
\hline & & Eurytoma curculionum $\mathrm{Mayr}^{3}$ & 8 & 11.8 \\
\hline & & Mesopolobus morys Walker ${ }^{1}$ & 8 & 11,8 \\
\hline & & Eupelmus sp. ${ }^{4}$ & 2 & 2,9 \\
\hline & & Trichomalus cf. perfectus Walker ${ }^{1}$ & 2 & 2,9 \\
\hline & & Trichomalus sp. $^{1}$ & 2 & 2,9 \\
\hline & & Eurytoma curculionum $\mathrm{Mayr}^{3}$ & 1 & 1,5 \\
\hline & & Pteromalus sp. ${ }^{1}$ & 1 & 1,5 \\
\hline & & Syntomopus sp. ${ }^{1}$ & 1 & 1,5 \\
\hline & \multirow[t]{5}{*}{ Hungary/Bekes - Site 18} & Pteromalus sequester Walker gr. ${ }^{1}$ & 11 & 61,1 \\
\hline & & Closterocerus sp. $^{2}$ & 4 & 22,2 \\
\hline & & Baryscapus sp. ${ }^{2}$ & 1 & 5,6 \\
\hline & & Eurytoma curculionum Mayr $^{3}$ & 1 & 5,6 \\
\hline & & Eupelmus sp. ${ }^{4}$ & 1 & 5,6 \\
\hline & \multirow[t]{2}{*}{ Hungary/ Sari - Site 19} & Mesopolobus morys Walker ${ }^{1}$ & 2 & 50,0 \\
\hline & & Pteromalus sequester Walker gr. ${ }^{1}$ & 2 & 50,0 \\
\hline & \multirow[t]{3}{*}{ Hungary/Gyal - Site 20} & Pteromalus sequester Walker gr. ${ }^{1}$ & 2 & 50.0 \\
\hline & & Eupelmus sp. ${ }^{4}$ & 1 & 25.0 \\
\hline & & Mesopolobus morys Walker ${ }^{1}$ & 1 & 25.0 \\
\hline & \multirow[t]{4}{*}{ Hungary Sari - Site 21} & Mesopolobus morys Walker ${ }^{1}$ & 2 & 40.0 \\
\hline & & Closterocerus sp. $^{2}$ & 1 & 20.0 \\
\hline & & Eurytoma curculionum Mayr $^{3}$ & 1 & 20.0 \\
\hline & & Pteromalus sequester Walker gr. ${ }^{1}$ & 1 & 20.0 \\
\hline
\end{tabular}

Chalcidoidea : 1Pteromalidae, 2 Eulophidae, 3Eurytomidae, 4Eupelmidae

\section{Discussion}

The two most common parasitoids of C. obstrictus, T. perfectus and M. morys, together with the less common S. gracilis account for up to $90 \%$ of C. obstrictus parasitism in Europe (Williams, 2003). It has recently been shown by Gibson et al. (2005) that neither T. perfectus nor M. morys are present in North America. Stenomalina gracilis however, occurs on $C$. obstrictus in low numbers in British Columbia (Gibson et al., in press). Prior to introduction 
of T. perfectus and M. morys for classical biological control of C. obstrictus in Canada, and before considering S. gracilis for augmentative biological control, it is essential to document their host ranges for the identification and exclusion of polyphagous agents to ensure potential non-target effects are avoided. Based on the principles proposed by Kuhlmann et al. (2006a), the phenological and geographical overlap of target (C. obstrictus) and non-target species (C. turbatus and C. typhae), added to the fact that the target and non-target species share the same feeding niche, clearly points towards a higher risk that parasitoids of the target species could attack the two non-target species. Following these principles, results of our studies should facilitate accurate prediction of potential non-target host impacts in the area of introduction.

The phenology of these ectoparasitoids is closely linked with those of their hosts. All ectoparasitoids encountered during our surveys laid eggs on late instar larvae of C. turbatus and C. typhae. The parasitoid larvae fed on their hosts for two to three weeks and pupated inside the pods. Pupation took approximately one to two weeks and adults of the new generation emerged through the openings of the senescent pods. Our studies on the phenology of C. turbatus support the results obtained by Cripps et al. (in press), Schwarzländer et al. (2002) and Hinz et al. (2003; 2004). Little was known regarding the phenology of C. typhae prior to our studies. Females of both species lay eggs in pods of their host plants between May and June. Larvae develop through three instars until they are mature and chew a hole in the pod wall to exit and pupate in the soil. Weevils of the new generation emerge between June and July of the same year. Both species overwinter in the adult stage, and the weevils become active again the following spring. Larvae of C. obstrictus also develop during May and July (Bonnemaison, 1957) confirming that its phenology overlaps with those of C. turbatus and C. typhae in the field. Furthermore, several studies showed that the geographical distribution of these three species also overlaps in Europe (Bonnemaison, 1957; Hinz et al., 2003; Hinz et al., 2004; Cripps et al., in press). Our result on the target and non-target host phenology comparison indicate that phenology overlap conditions are met, which could lead to a higher risk of non-target effects, according to Kuhlmann et al. (2006a), in the case of classical biological control of C. obstrictus in Canada. The remaining question of our study aimed at answering whether these three Ceutorhynchionae host species share some of the parasitoid species among their parasitoid assemblages, with particular interest on the candidate biological control agents of C. obstrictus, M. morys and/or T. perfectus.

Several new host-parasitoid associations were identified in our study. Concerning the parasitoid assemblage associated with C. typhae, our observations led to the discovery of two species, one of them, Mesopolobus gemellus, is new to science. This species was responsible 
for $98 \%$ of the parasitism at all sites studied. The second species associated with C. typhae was the pteromalid S. gracilis, with only a single parasitism record on C. typhae. Overall parasitism reached on average $25 \%$ of all $C$. typhae hosts available to parasitoids at all sites surveyed.

In contrast to C. typhae on shepherd's purse, C. turbatus on hoary cress had a more species rich parasitoid assemblage with 10 species involved. Interestingly, M. morys, the candidate agent for $C$. obstrictus, was the most common parasitoid of $C$. turbatus and reached up to $40 \%$ of total parasitism. In addition, this species was present at almost all sites where $C$. turbatus was collected on hoary cress in Switzerland and Hungary. The second most important ectoparasitoid species parasitizing C. turbatus was $P$. sequester, which represents $37 \%$ of the parasitoid assemblage and was also present at almost all sites studied. The eurytomid wasp E. curculionum had previously been associated with C. obstrictus by Dmoch (1975a). Our study provides the first record of its association with C. turbatus on hoary cress. Interestingly, while this parasitoid is known to occur in France (Thompson, 1955; Herting, 1973) and Germany (Freese, 1995; Vidal, 1997), we only observed occurrences of E. curculionum on C. turbatus in Hungary. Several other parasitoid species such as Closterocerus sp., Baryscapus sp., Trichomalus sp., Pteromalus sp. and Syntomopus sp. were also encountered only in Hungary during our surveys, and their association with C. turbatus is new to science. Two specimens of a Trichomalus species near T. perfectus were collected, together representing less than $1 \%$ of all the parasitoid specimens obtained during our surveys.

Kruess \& Tscharntke (2000) demonstrated that fragmentation of habitats negatively affects species diversity and species abundance, and that species diversity can be dramatically reduced by both area-loss and increasing habitat isolation. Our results indicate that parasitoid assemblages associated with C. turbatus were more species-rich in Hungary (4.4 \pm 1.2$)$ than in Switzerland (1.9 \pm 0.3 ). Furthermore, Tscharntke \& Brandl (2004) defined that species richness and abundance of natural enemies are often closely correlated, so that the "single species" impact of a species-poor, but individual-rich community of beneficials cannot easily be separated from the "multiple-species" impact of a species-rich community with only few individuals per species. During our studies, we found no significant difference in average parasitism levels between Switzerland (36.4 $\pm 6.6 \%)$ and Hungary $(27.0 \pm 4.3 \%)$, which tends to confirm the conclusions drawn by Tscharntke \& Brandl (2004). In addition, the parasitoid assemblage of $T$. typhae is on average less species-rich $(1.1 \pm 0.1)$ than that of $T$. turbatus (3.1 \pm 0.7$)$. However, as mentioned above, species-richness depends on a wide range of factors 
and thus can vary from one sampling region to the other. As a consequence, to be able to accurately assess differences in parasitoid assemblage species-richness between species, surveys should be carried out in parallel in the same sampling regions.

Concerns regarding non-target effect issues in arthropod biological control have been rising for over ten years (Howarth, 1991; Simberloff \& Stiling, 1996; Thomas \& Willis, 1998; Stiling \& Simberloff, 2000; Louda, 2003; Stiling, 2004). Consequently, a number of studies have dealt with this topic, and several guidelines have been drawn (Babendreier et al., 2005; Simberloff, 2005; Wright et al., 2005; Kuhlmann et al., 2006b) to help accurately assess the risks associated with the introduction of non-native species for biological control of arthropods. Our work benefited from following these guidelines and recommendations, and our results show that accurate prediction of potential risks can be made. In addition, these results prove that, as proposed by Babendreider et al.(2005), field studies in the area of origin of candidate agents are very valuable and can aid in the prediction of potential risks in the area of introduction.

As an outcome of these natural enemy host range surveys in Europe, it is clear that $M$. morys was the most common species parasitizing C. turbatus on hoary cress in Switzerland and Hungary. These findings will have direct implications on the biological control of $C$. obstrictus. In the case of both an introduction of $M$. morys as a biological control agent against $C$. obstrictus, and the release of $C$. turbatus as a biological control agent against hoary cress, potential conflicts might occur between the two programmes. In contrast, no evidence was found that $T$. perfectus attacks either C. turbatus or C. typhae, and therefore it appears that this species would pose no risk should it be introduced for biological control of $C$. obstrictus in Canada. 


\section{Acknowledgments}

We acknowledge Emmanuel Cuenot (France), Virginia Larraz (Spain), Leonore Lovis (Switzerland), Gabor Nagy (Hungary), Fezekas Janos (Hungary), Alicia Leroux (Canada), Lars Andreassen (Canada), for their precious help as part of the CABI Agricultural Pest Research dissection team. We appreciated the fruitful discussions with Dr. Hariet Hinz and Dr. Stefan Toepfer (both CABI) and acknowledge them as well for information exchanged on collection sites of Lepidium draba in various European countries. Mr. Hannes Baur, Natural History Museum, Bern, Switzerland and Dr. Gary Gibson, Canadian National Collection, Ottawa, Ontario, Canada identified the chalcid parasitoids. This work was funded by Agriculture and Agri-Food Canada, AAFC's Pest Management Research Centre Project PRR03-370, and the Alberta Agricultural Research Institute. 


\section{References}

Andriescu, I. \& M. D. Mitroiu (2001). Contributions to the knowledge of the pteromalids (Hymenoptera, Chalcidoidea, Pteromalidae) from David's Valley hay fields natural reserve, Iasi (II). Analele Stiintifice ale Universitatii "Al. I. Cuza" din Iasi. Serie Noua - Biologie Animala 47, 21-28.

Babendreier, D., F. Bigler \& U. Kuhlmann (2005). Methods used to assess non-target effects of invertebrate biological control agents of arthropod pests. BioControl 50 (6), 821870 .

Baur, H., F. J. Muller, G. A. P. Gibson, P. G. Mason \& U. Kuhlmann (submitted). A review of the species of Mesopolobus (Hymenoptera: Chalcidoidea) associated with Ceutorhynchus (Coleoptera: Curculionidae) host-species of European origin. Bulletin of Entomological Research.

Bonnemaison, L. (1957). Le charancon des siliques (Ceutorhynchus assimilis Payk.) Biologie et Méthodes de lutte. Annales de l'institut national de la recherche agronomique Serie C: Annales des Epiphytes 8 (IV), 387-542.

Born, W., F. Rauschmayer \& I. Brauer (2005). Economic evaluation of biological invasions a survey. Ecological Economics 55, 321- 336.

Boucek, Z. (1977). A faunistic review of the Yugoslavian Chalcidoidea (Parasitic Hymenoptera). Acta Entomologica Jugoslavica 13 (Supppl. 32), 1-145.

Bouchard, P., L. Lesage, H. Goulet, N. J. Bostanian, C. Vincent, A. Zmudzinska \& J. Lasnier (2005). Weevil (Coleoptera: Curculionoidea) Diversity and Abundance in Two Quebec Vineyards. Annals of the Entomological Society of America 98 (4), 565-574.

Bousquet, Y. (1991). Checklist of beetles of Canada and Alaska. Agricucture Canada Publ. 1861/E. 430 pp.

Budd, A. C. \& K. F. Best (1969). Wild Plants of the Canadian Prairies. Canada Department of Agriculture Research Branch - Publication 983. 519 pp.

Buechi, R. (1993). Monitoring of parasitoids of the cabbage seed weevil, Ceutorhynchus assimilis during 1990 and 1991 in Switzerland. In: V. H. Paul, I. H. Willians and P. 
Gladders (Eds.) Proceedings of the Working group "Integrated control in oilseed crops". Bulletin OILB/SROP. Le Rheu, France. 16, 145-149.

Carcamo, H. A., L. M. Dosdall, D. Johnson \& O. Olfert (2005). Evaluation of foliar and seed treatments for control of the cabbage seedpod weevil (Coleoptera: Curculionidae) in canola. The Canadian Entomologist 137, 476-487.

Clausen, C. P. (1940). Entomophagous Insects. In: A. F. Shull (Ed.) McGraw-Hill Publications in the Zoological Sciences. McGraw-Hill, New York. 120-131.

Colonnelli, E. (2004). Catalogue of Ceutorhynchinae of the world, with key to genera. Argania edito, Balmes, Barcelona. 124 pp.

Cripps, M. G., H. L. Hinz, J. L. McKenney, B. L. Harmon, F. W. Merickel \& M. Schwarzlaender (in press). Comparative survey of the phytophagous arthropod faunas associated with Lepidium draba in Europe and the western United States, and the potential for biological weed control. Biocontrol Science and Technology.

Dawson, M. (2002). Plant quarantine: preventing the introduction and spread of alien species harmful to plants. In: R. Claudi, P. Nantel and E. Muckel-Jeffs (Eds.) Alien invaders in Canada's waters, wetlands, and forests. Canadian Forest Service, Natural Resources Canada, Ottawa, ON, Publication Fo42-329/2002E. 243-251.

Dmoch, J. (1975a). Study on the parasites of the cabbage seedpod weevil (Ceutorhynchus assimilis Payk.). I. Species composition and economic importance of the larval ectoparasites. Roczniki Nauk Rolniczych 5 (1), 99-112.

Dmoch, J. (1975b). Study on the parasites of the cabbage seedpodweevil (C. assimilis Payk. ). II. Relations between the times of occurrence and development of the cabbage seed weevil and those of its parasites on the winter rape (in pollish). Roczniki Nauk Rolniczych 5 (1), 113-124.

Dmoch, J. \& G. Klimek (1975). Study on the parasites of the cabbage seed weevil (Ceutorhynchus assimilis Payk.). III. Observations on the biology of Trichomalus perfectus (Walker). Roczniki Nauk Rolniczych 5 (1), 125-136.

Dosdall, L. M., D. Moisey, H. A. Carcamo \& R. Dunn (2001). Cabbage seedpod weevil fact sheet. Alberta Agriculture, Food and Rural Development Agdex 622-21, 1-4.

Dosdall, L. M. \& D. W. A. Moisey (2004). Developmental biology of the cabbage seedpod weevil, Ceutorhynchus obstrictus (Coleoptera: Curculionidae), in spring canola, Brassica napus, in western Canada. Annals of the Entomological Society of America 97 (3), 458-465. 
Fischer, J. P. (1965). A contribution to the biology of Eurytoma curculionum Mayr (Hym., Eurytomidae). Entomophaga 10 (4), 317-318.

Fox, A. S. \& L. Dosdall (2003). Reproductive biology of Ceutorhynchus obstrictus (Coleoptera: Curculionidae) on wild and cultivated Brassicaceae in southern Alberta. Journal of Entomological Science 38, 533-544.

Freese, G. (1995). Structural refuges in two stem-boring weevils on Rumex crispus. Ecological Entomology 20 (4), 351-358.

Gibson, G. A. P., H. Baur, B. Ulmer, L. Dosdall \& F. J. Muller (2005). On the misidentification of the chalcid (Hymenoptera: Chalcidoidea) parasitoids of the cabbage seedpod weevil (Coleoptera: Curculionidae) in North America. The Canadian Entomologist 137, 381-403.

Gibson, G. A. P., D. R. Gillespie \& L. M. Dosdall (in press). The species of Chalcidoidea (Hymenoptera) introduced to North America for biological control of the cabbage seedpod weevil, and the first recovery of Stenomalina gracilis (Chalcidoidea: Pteromalidae). The Canadian Entomologist.

Graham, M. W. R. (1969). The Pteromalidae of North-Western Europe (Hymenoptera: Chalcidoidea). Bulletin of the British Museum (Natural History) Entomology (Suppl.16), 908pp.

Gumovski, A. V. (2001). The status of some genera allied to Chrysonotomyia and Closterocerus (Hymenoptera: Eulophidae, Entedoninae), with description of a new species from Dominican amber. Phegea 29 (4), 125-141.

Hansson, C. (1990). A taxonomic study on the Palearctic species of Chrysonotomyia Ashmead and Neochrysocharis Kurdjumov (Hymenoptera: Eulophidae). Entomologica Scandinavica 21, 29-52.

Hansson, C. (1994). Re-evaluation of the genus Closterocerus Westwood (Hymenoptera: Eulophidae), with a revision of the Nearctic species. Entomologica Scandinavica 25, $1-25$.

Hansson, C. (1996). Taxonomic revision of the Nearctic species of Omphale Haliday (Hymenoptera: Eulophidae). Entomologica Scandinavica (suppl. 49), 1-78.

Herting, B. (1973). Coleoptera to Strepsiptera. Section A. Host or Prey/Enemy. In: A catalogue of parasites and predators of terrestrial arthropods. Commonwealth Agricultural Bureaux, Institute of Biological Control. 185pp. 
Hinz, H. L., M. Cripps, K. Medina \& H. Recher (2003). Biological control of whitetops, Lepidium draba and L. appelianum, Unpublished Report, CABI Bioscience Switzerland Centre, Delémont.32pp.

Hinz, H. L., M. Cripps, B. J. L. Renteria \& A. Wins-Purdy (2004). Biological control of whitetops, Lepidium draba and L. appelianum, Unpublished Report, CABI Bioscience Switzerland Centre, Delémont.36pp.

Howarth, F. G. (1991). Environmental impacts of classical biological control. Annual Review of Entomology 36, 485-509.

Kruess, A. \& T. Tscharntke (2000). Effects of habitat fragmentation on plant-insect communities. In: B. Ekbom, M. E. Irwin and Y. Robert (Eds.) Interchanges of insects between agricultural and surrounding landscapes. Kluwer Academic Publishers, Dordrecht. 53-70.

Kuhlmann, U., L. M. Dosdall \& P. G. Mason (2002). Ceutorhynchus obstrictus (Marsham), cabbage seedpod weevil (Coleoptera: Curculionidae). In: P. G. Mason and J. T. Huber (Eds.) Biological Control Programmes in Canada, 1981-2000. CABI Publishing, Wallingford, Oxon, U.K. 52-58.

Kuhlmann, U. \& P. G. Mason (2002). Use of field host range surveys for selecting candidate non-target species for physiological host specificity testing of entomophagous biological control agents. In: R. G. Van Driesche (Ed.) Proceedings of the 1st International Symposium on Biological Control of Arthropods. United States Department of Agriculture, Forest Service, Washington, USA Hawaii. 370-377.

Kuhlmann, U., P. G. Mason, H. L. Hinz, B. Blossey, R. A. De Clerck-Floate, L. Dosdall, J. P. McCaffrey, M. Schwarzlaender, O. Olfert, J. Brodeur, A. S. McClay \& R. N. Wiedenmann (2006a). Avoiding conflicts between insect and weed biological control: selection of non-target species for test list to assess host specificity of cabbage seedpod weevil parasitoids. Journal of Applied Entomology 130 (3), 129-141.

Kuhlmann, U., U. Schaffner \& P. G. Mason (2006b). Selection of non-target species for host specificity testing. In: F. Bigler, D. Babendreier and U. Kuhlmann (Eds.) Environmental impact of invertebrates for biological control of Arthropods: Methods and risk assessment. CABI Publishing., Wallingford, Oxon, UK. 15-37.

Leeson, J. Y., A. G. Thomas, L. M. Hall, C. A. Brenzil, T. Andrews, K. R. Brown \& R. C. Van Acker (2005). Prairie weed surveys of cereal, oilseed and pulse crops from the 1970s to the 2000s, Weed Survey Series Publication 05-1CD. Agriculture and AgriFood Canada, Saskatoon Research Centre, Saskatoon, Saskatchewan. 
Louda, S. M., et al. (2003). Nontarget effects: the Achilles' heel of biological control? Retrospective analysis to reduce risk associated with biocontrol introductions. Annual Review of Entomology 48, 365-396.

Mey, W. (1993). On the parasitization of the pear blister moth Leucoptera malifoliella (Costa) (Lep., Lyonetiidae) in the fruit-growing area of Havellandisches Obstbaugebiet. Journal of Applied Entomology 115 (4), 331-335.

Mitroiu, M. D. (2001). Revision of the Chalcidoidea: Pteromalidae (Hymenoptera) collections of the Belgian Royal Institute of Natural Sciences and the discovery of 31 new species for Belgium. Bulletin de la Société Royale Belge d'Entomologie 137, 91-97.

Moss, E. H. (1959). Flora of Alberta. University of Toronto Press, Toronto, Ontario. 546 pp.

Muller, F. J., E. Cuenot \& U. Kuhlmann (2004). Biological control of cabbage seedpod weevil, Ceutorhynchus obstrictus. Annual report 2003-2004, CABI Bioscience Switzerland Centre, Delémont, Switzerland. 24pp.

Muller, F. J., T. D. Gariepy \& U. Kuhlmann (2003). Biological control of cabbage seedpod weevil, Ceutorhynchus obstrictus. Annual report 2002-2003, CABI Bioscience Switzerland Centre, Delémont, Switzerland. 24pp.

Murchie, A. K. \& I. H. Williams (1998). A bibliography of the parasitoids of the cabbage seed weevil (Ceutorhynchus assimilis Payk.). IOBC wprs Bulletin 21 (5), 163-169.

Noyes, J. S. (2006). Universal Chalcidoidea Database. www.nhm.ac.uk/entomology/chalcidoids/index.html. last accessed 20-April-2006.

Parnell, J. R. (1964). The parasite complex of two seed beetles Bruchidius ater Marsh (Col., Bruchidae) and Apion fuscirostre Fbr. (Col., Curculionidae). Transactions of the Royal Entomological Society of London 116, 73-88.

Perrings, C., M. Williamson, E. B. Barbier, D. Delfino, S. Dalmazzone, J. Shogren, P. Simmons \& A. Watkinson (2002). Biological invasion risks and the public good: an economic perspective. ConservationEcology 6 (1), art. No. 1.

Pimentel, D., L. Lach, R. Zuniga \& D. Morrison (2000). Environmental and economic costs of nonindigenous species in the United States. BioScience 50 (1), 53-65.

Schauff, M. E. (1991). The Holarctic genera of Entedoninae (Hymenoptera: Eulophidae). Contributions of the American Entomological Institute 26 (4), 109pp. 
Schwarzlaender, M., J. McKenney \& M. Cripps (2002). Biocontrol pre-release studies on hoary cress in Idaho, adjacent states, and central Europe - Progress Report, Department of Plant, Soil, and Entomological Sciences University Of Idaho Moscow, ID 83844-2339, USA. 11pp.

Simberloff, D. (2005). The politics of assessing risk for biological invasions: the USA as a case study. Trends in Ecology and Evolution 20 (5), 216-222.

Simberloff, D. \& P. Stiling (1996). How risky is biological control? Ecology 77, 1965-1974.

Stiling, P. (2004). Biological control not on target. Biological invasions 6, 151-159.

Stiling, P. \& D. Simberloff (2000). The frequency and strength of nontarget effects of invertebrate biological control agents of plant pests and weeds. In: P. A. Follet and J. J. Duan (Eds.) Nontarget Effects of Biological Control. Kluwer Academic Publishers, Norwell/USA. 31-43.

Szczepanski, H. (1972). The rape Pteromalid - Trichomalus perfectus (Walk.) (Hymenoptera, Pteromalidae) in forest biocoenosis and the problem of the biological protection of rape. Polskie Pismo Entomologiczne 42 (4), 865-871.

Takagi, M. (1985). The reproductive strategy of the gregarious parasitoid, Pteromalus puparum (Hymenoptera: Pteromalidae). Oecologia 68 (1), 1-6.

Thomas, M. B. \& A. J. Willis (1998). Biocontrol - risky but necessary? Trends in Ecology and Evolution 13 (8), 325-329.

Thompson, W. R. (1955). Section 2: Host parasite catalogue, Part 3: Hosts of the Hymenoptera (Calliceratid to Evaniid). . In: A catalogue of the parasites and predators of insect pests. Commonwealth Agricultural Bureaux, The Commonwealth Institute of Biological Control, Ottawa, Ontario, Canada. 327

Tscharntke, T. \& R. Brandl (2004). Plant-insect interactions in fragmented landscapes. Annual Review of Entomology 49, 405-430.

Vidal, S. (1993). Determination list of entomophagous insects No 12. Bulletin Section Regionale Ouest Palaearctique, Organisation Internationale de Lutte Biologique 16 (3), 1-28.

Vidal, S. (1997). Determination list of entomophagous insects. Nr. 13. Bulletin Section Regionale Ouest Palaearctique, Organisation Internationale de Lutte Biologique 20 (2), 1-25. 
Williams, I. H. (2003). Parasitoids of Cabbage Seed Weevil. In: D. V. Alford (Ed.) Biocontrol of Oilseed Rape Pests. Blackwell Science, Oxford. 97-112.

Wittenberg, R. \& M. J. W. Cock (Eds.) (2001). Invasive Alien Species: A Toolkit of Best Prevention and Management Practices. CABI Publishing, Wallingford, Oxon, UK. $228 \mathrm{pp}$.

Wright, M. G., M. P. Hoffmann, T. P. Kuhar, J. Gardner \& S. A. Pitcher (2005). Evaluating risks of biological control introductions: A probabilistic risk-assessment approach Biological Control 35 (3), 338-347.

Yu, D., K. Van Achterberg, K. Horstmann \& J. S. Noyes (2005). Taxapad. Vancouver, BC, Canada. 


\section{Discussion}

One of the many constraints biological control practitioners very frequently encounter during the course of their research is that the taxonomy of the groups involved is often unclear (Huber et al., 2002; Van Driesche \& Reardon, 2004). As Bigler et al. (2005) emphasized, there is a need to provide an accurate identification of the candidates prior to introduction of candidate biological control agents. In addition, sufficient characterization of the agent to allow its unambiguous recognition should be provided, as well as relevant supporting taxonomic information such as general diagnostic descriptions and details of any taxonomic difficulties within the group (Bigler et al., 2005).

Without a doubt, the attempt at biological control of Ceutorhynchus obstrictus (Marsham) [=C. assimilis (Paykull); see Colonnelli (2004)] initiated in 1949 would have benefited from following these guidelines, and the succession of misidentifications retrospectively demonstrated by Gibson et al. (2005) illustrates remarkably well Bigler's (2005) statement. This first classical biological control attempt resulted in the release of three European pteromalid parasitoid species in Canada (McLeod, 1953). In their recent study, Gibson et al. (2005) demonstrated that the species introduced had been misidentified. In addition, the records of species subsequently reared from Brassica spp. seedpods pods in Canada and reported in the literature as the three originally introduced species were also shown to be based on misidentifications. Therefore, two of the three species introduced, Trichomalus perfectus and Mesopolobus morys, never established. These misidentifications could have had an important impact on the new attempt at biological control of $C$. obstrictus initiated by Agriculture and Agri-Food Canada in 2000. In fact, as both species were still thought to be present in British Columbia, Canada, a decision could have been made to redistribute them within Canada without further investigation, potentially leading to the use of misidentified species and consequently to a greater risk of associated non-target effects.

Fortunately, prior to any action, a decision was made to study in detail the taxonomy of Trichomalus and Mesopolobus in parallel in North America and in Europe and to assess the ecological host range of selected C. obstrictus parasitoids in Europe

First, the taxonomic status of Mesopolobus and Trichomalus species associated with the pest and other Ceutorhynchinae species in Europe was revised to prevent such failures in the 
future. Consequently to this study, Trichomalus rusticus (Walker) is now treated as a valid species, resurrected from synonymy under T. lucidus (Walker), and T. lyttus (Walker) is transferred from synonymy under T. lucidus and newly placed in synonymy with T. rusticus. In addition, a new species of Mesopolobus has been described, Mesopolobus gemellus Baur \& Muller sp. nov., and associated with Ceutorhynchus typhae (Herbst) [=C. floralis Paykull] on shepherd's purse, Capsella bursa-pastoris (L.) Medicus [Brassicaceae]. However, as the species has only recently been described, and is very closely related to M. morys and may have been misidentified as such in the past, additional host associations that might exist will be described in the future.

These results emphasize the importance of taxonomy in classical biological control programs and document the need to follow recently proposed guidelines (Bigler et al., 2005; Gibson et al., 2005; Wright et al., 2005; Kuhlmann et al., 2006a; Kuhlmann et al., 2006b; Gibson et al., in press; Gillespie et al., submitted). Furthermore, it should be taken into consideration that the problems resulting from poor knowledge of the taxonomy of candidate agents could affect inundative biological control programs, when a species is redistributed from an area of a country where it is already present to other areas where its presence is needed.

The potential threat to the environment that might exist in case of an introduction of candidate biological control agents for the control of C. obstrictus in Canada was studied following recent recommendations made by Bigler et al. (2005), Barbendreier et al. (2005) and Kuhlmann et al. (2006b) who emphasized the fact that the potential risk for non-target effects is higher when target and non-target species 1) show an overlap in time of occurrence; 2) have overlapping geographical distributions and 3) share the same feeding niches in habitats. As a result of this approach, the very first step in every biological control project should be to collect all available information on the potential host(s) of the candidate biological control agent(s) (Babendreier et al., 2005). However, documenting parasitoid host ranges is far more complicated than collecting data on host parasitoid species load because it involves rearing parasitoids to the adult stage for identification from different species of hosts rather than rearing or dissecting many individuals of a single host species (Kuhlmann et al., 2006b). Nevertheless, even though they are sometimes difficult to conduct, field surveys in the country of origin are very valuable (Babendreier et al., 2005). Following this principle, we carried out studies in Europe to 1) document the phenology of four non-target Ceutorhynchinae hosts with the aim of verifying whether or not the target and non-target species show an overlap in time of occurrence with the target, C. obstrictus; 2) assess the 
parasitoid assemblages associated with these species in order to determine the potential for $T$. perfectus and $M$. morys to utilize non-target hosts ecologically related to the target host.

Results showed that in Europe, M. morys is the most abundant species parasitizing the seed feeder Ceutorhynchus turbatus (Schultze), a candidate parasitoid for biological control of the weed hoary cress, Lepidium draba L. (=Cardaria draba) [Asteraceae], in North America. In case both species would be further considered for introduction, there exists a risk that potential conflicts could occur between these arthropod biological and weed biological control programmes in the future. Decisions might have to be made on time by balancing environmental risks and potential benefits as proposed by Bigler et al. (2006).

Furthermore, Stenomalina gracilis Walker was found to be associated with Microplontus edentulus (Schultze), a biological control agent against the weed scentless chamomile, Tripleurospermum perforatum (Mérat) Laínz (=Matricaria perforata Mérat) [Asteraceae], in North America. Recently Gibson et al. (in press) documented the presence of S. gracilis in Canada in the same region where it had been released in 1949. A consequence of the study by Gibson et al. (in press) is that $S$. gracilis could be legally considered for further release or redistribution in the future. We propose that $S$. gracilis should not be further considered because our results show that its use would potentially lead to conflicting situations with weed biological control in Canada.

On the other hand, T. perfectus has not been found parasitizing any of the four non-target Ceutorhynchinae host species studied. Taking this into consideration, it appears from the current state of our knowledge that $T$. perfectus possesses desirable qualities for introduction into Canada (e.g. narrow host range, ability to successfully suppress pest populations in Europe).

Our results constitute a first step in understanding the risks associated with an introduction of these potential agents to North America. In their attempt at comparing results obtained in fundamental host range vs. ecological host range assessment studies, Haye et al. (2005) concluded that ecological host range studies in the area of origin provide a useful supplement to interpret laboratory host range testing to predict the behaviour of a biological control agent after introduction. Thus, Haye et al. (2005) propose that a complete host range evaluation should combine data from the literature, field collections, and laboratory experiments, the latter being the next step that future studies on the biological control of C. obstrictus will envisage. Indeed, eventhough the life cycles of the candidate parasitoids T. perfectus and $M$. morys has already been documented in the past (Bonnemaison, 1957; Dmoch, 1975b; Dmoch, 
1975a; Buechi, 1993; Murchie \& Williams, 1998), several characteristics of their biology (e.g. overwintering behaviour, cold hardiness, reproductive potential) that may be easier to investigate in laboratory studies remain unknown and will have to be assessed prior to any introduction. 


\section{References}

Babendreier, D., F. Bigler \& U. Kuhlmann (2005). Methods used to assess non-target effects of invertebrate biological control agents of arthropod pests. BioControl 50 (6), 821870.

Bigler, F., J. S. Baleb, M. J. W. Cock, H. Dreyer, R. Greatrex, U. Kuhlmann, A. J. M. Loomans \& J. C. Van Lenteren (2005). Guidelines on information requirements for import and release of invertebrate biological control agents in European countries. CAB Reviews: Perspectives in Agriculture, Veterinary Science, Nutrition and Natural Resources 1 (001), 1-10.

Bigler, F. \& U. Kölliker-Ott (2006). Balancing environmental risks and benefits: a basic approach. In: F. Bigler, D. Babendreier and U. Kuhlmann (Eds.) Environmental impact of invertebrates for biological control of Arthropods: Methods and risk assessment. CABI Publishing, Wallingford, Oxon, UK. 273-286.

Bonnemaison, L. (1957). Le charancon des siliques (Ceutorhynchus assimilis Payk.) Biologie et Méthodes de lutte. Annales de l'institut national de la recherche agronomique Serie C: Annales des Epiphytes 8 (IV), 387-542.

Buechi, R. (1993). Monitoring of parasitoids of the cabbage seed weevil, Ceutorhynchus assimilis during 1990 and 1991 in Switzerland. In: V. H. Paul, I. H. Willians and P. Gladders (Eds.) Proceedings of the Working group "Integrated control in oilseed crops". Bulletin OILB/SROP. Le Rheu, France. 16, 145-149.

Colonnelli, E. (2004). Catalogue of Ceutorhynchinae of the world, with key to genera. Argania edito, Balmes, Barcelona. 124 pp.

Dmoch, J. (1975a). Study on the parasites of the cabbage seedpod weevil (Ceutorhynchus assimilis Payk.). I. Species composition and economic importance of the larval ectoparasites. Roczniki Nauk Rolniczych 5 (1), 99-112.

Dmoch, J. (1975b). Study on the parasites of the cabbage seedpodweevil (C. assimilis Payk. ). II. Relations between the times of occurrence and development of the cabbage seed weevil and those of its parasites on the winter rape (in pollish). Roczniki Nauk Rolniczych 5 (1), 113-124.

Gibson, G. A. P., H. Baur, B. Ulmer, L. Dosdall \& F. J. Muller (2005). On the misidentification of the chalcid (Hymenoptera: Chalcidoidea) parasitoids of the cabbage seedpod weevil (Coleoptera: Curculionidae) in North America. The Canadian Entomologist 137, 381-403. 
Gibson, G. A. P., D. R. Gillespie \& L. M. Dosdall (in press). The species of Chalcidoidea (Hymenoptera) introduced to North America for biological control of the cabbage seedpod weevil, and the first recovery of Stenomalina gracilis (Chalcidoidea: Pteromalidae). The Canadian Entomologist.

Gillespie, D. R., P. G. Mason, L. M. Dosdall, P. Bouchard \& G. A. P. Gibson (submitted). Importance of long-term research in classical biological control: an analytical review of a release against the cabbage seedpod weevil in North America. Journal of Applied Entomology.

Haye, T., H. Goulet, P. G. Mason \& U. Kuhlmann (2005). Does fundamental host range match ecological host range? A retrospective case study of a Lygus plant bug parasitoid. Biological Control 35, 55-67.

Huber, J. T., S. Darbyshire, J. Bisset \& R. G. Footit (2002). Taxonomy and biological control. In: P. G. Mason and J. T. Huber (Eds.) Biological control programmes in Canada, 1981-2000. CABI Publishing. 14-22.

Kuhlmann, U., P. G. Mason, H. L. Hinz, B. Blossey, R. A. De Clerck-Floate, L. Dosdall, J. P. McCaffrey, M. Schwarzlaender, O. Olfert, J. Brodeur, A. S. McClay \& R. N. Wiedenmann (2006a). Avoiding conflicts between insect and weed biological control: selection of non-target species for test list to assess host specificity of cabbage seedpod weevil parasitoids. Journal of Applied Entomology 130 (3), 129-141.

Kuhlmann, U., U. Schaffner \& P. G. Mason (2006b). Selection of non-target species for host specificity testing. In: F. Bigler, D. Babendreier and U. Kuhlmann (Eds.) Environmental impact of invertebrates for biological control of Arthropods: Methods and risk assessment. CABI Publishing., Wallingford, Oxon, UK. 15-37.

McLeod, J. H. (1953). Notes on the cabbage ceedpod weevil, Ceutorhynchus assimilis (Payk.) (Coleoptera : Curculionidae), and its parasites. Entomological Society of British Columbia, Proc. 49, 11-18.

Murchie, A. K. \& I. H. Williams (1998). A bibliography of the parasitoids of the cabbage seed weevil (Ceutorhynchus assimilis Payk.). IOBC wprs Bulletin 21 (5), 163-169.

Van Driesche, R. G. \& R. Reardon (2004). Assessing host ranges for parasitoids and predators used for classical biological control: A guide to best practice. Forest Health Technology Enterprise Team, USDA-Forest Service, Morgantown, WV, USA. 243 pp.

Wright, M. G., M. P. Hoffmann, T. P. Kuhar, J. Gardner \& S. A. Pitcher (2005). Evaluating risks of biological control introductions: A probabilistic risk-assessment approach Biological Control 35 (3), 338-347. 


\section{Acknowledgments}

One of the pleasures I see of finally finishing this work is to have the opportunity to thank the numerous individuals who have given me so much throughout the course of my $\mathrm{PhD}$. Some would say they are too numerous to name. Instead of this, I'll apologize in advance for being too long, and will try not to forget too many of them because 1) without their help that work would not have been feasible, 2) in any or the other way they made my life easier and happier, and 3 ) citing them here is the least I could do to thank them.

I would first of all like to express my gratitude to my supervisor, Dr. Ulrich Kuhlmann, whose expertise, understanding, and patience, added considerably to my experience. Thank you Ulli for all the assistance you provided at all levels of the research project at the CABI Switzerland Centre. Thank you also for the good times we spent barbecuing on your balcony, Agriculturehiking in the Swiss Alps, and all the great moments you made possible by gathering together such a nice international team at the Arthropod Biological Control section over the years. Finally, I should apologize for having significantly increased your stress load over the past four years...

Very special thanks go to my referee, Prof. Dr. Stefan Vidal, without whose help things would have been undoubtedly much more complicate. I acknowledge him for the confidence he placed in me, allowing my research to be carried out abroad. In addition, I would of course like to thank the members of my committee, Prof. Dr. Teja Tscharntke and Prof. Dr. Matthias Schaefer for taking time out from their busy schedules to take part in that final evaluation process.

It is under the tutelage of Hannes Baur that I developed a focus and became interested in the taxonomy of chalcid wasps. Hannes offered his time and patience and taught me everything I know about identification of these tiny little insects, starting from scratch. I appreciated the time we spent working together, especially while listening to some of the best jazz musicians ever! 
I acknowledge Peter Mason, Gary Gibson and Lloyd Dosdall for the help they provided in so many different ways. Thank you all for helping me with my research and writing and for your continuous availability over the past four years.

I would also like to express my gratitude to Emmanuel "Manu" Cuenot and Virginia Larraz, without whose motivation, seriousness and reliability that work could have been a lot more difficult. You came as "summer students", and left as good friends. Thanks for all your time and dedication, I greatly appreciated all your efforts and wanted to make sure you both had realized that;)

Appreciation also goes out to my many lab mates, for all of their help and support, discussions, good laughs and long evenings in the lab and elsewhere. I think first of course of Tara Gariepy \& Kim Riley for all the good (and/or bad) times... and for the timeless gossiping sessions!!

I would also like to thank the rest of the CABI Agriculture team: Manfred Grossrieder, Beate Kiefer, Leonore Lovis, Feng Zhang, Wade Jenner, Tim Haye, Alicia Leroux, Lars Andreassen, Emma Hunt, Jake Miall, Erik Osborne, Leyla Valdivia, for all the instances in which their assistance helped me along the way. Furthermore, thanks to all those who have taken part in the "dissection team" and "pods mass collection team". I know it sounds insane, but together that's 4,000 meters of stems (the height of the Matterhorn!!), and 60,000 pods that we have individually dissected, not counting the approximately 200,000 pods we have mass collected... Thank you all ;)

I would especially like to thank Tara, Wade, Alicia, Lars, Jane and all those who corrected my English in countless reports, abstracts and papers over the years.

In addition, because doing research is always a team effort, my gratitude also goes to those who provided me with their:

- Scientific advices, exchanges of knowledge and skills: Esther Gerber, Andre Gassmann, Hariet Hinz and Stefan Toepfer. I appreciated their helpful advices and insightful comments over the course of my studies;

- Everyday technical assistance: Monique Gyseler for her availability and her ability at ALWAYS finding a good solution, Remy-THE-computer-man, Christian, Michel and many more...

- Technical assistance from distant places: Beate Klander \& Maren Belde, Stephen Maggins, for their help in collecting plants in Germany; Gabor Nagy and Janos Fezekas for 
the incredible amount of work they carried out in Hungary in 2004, even if communication was sometimes difficult, I still hope they realized how much their help has been appreciated;

- Taxonomic expertise: Hannes and Gary of course, but also Dr. Kees van Achterberg, Dr. Klaus Horstmann and Michael Gates;

- Presence and help: Patrick Haefliger, Michael Cripps, Heike Kuhlmann, Ruediger, Gitta, Urs...well, the whole Delémont team!

I have made many friends along the way. They have helped me, one way or another, in my struggle to complete a Ph.D. I would especially like to thank Ghislaine Cortat \& René Eschen for their help during the last few months, and for all the good moments we've had together in Switzerland. Now get to your bicycles, time is coming when we'll go cycling around France and Europe together!! Thanks as well to Sandrine Girardoz and Thomas Spiegelberger for all our chats at coffee breaks during those long winters at CABI ;)

Appreciation also goes to the "Bouvet family and affiliates", Martine \& Pierre for so much kindness and comforting support over the years, Marco for the good laughs, and of course "les responsables du gite de l'Orsière" for the welcoming smell of a good cheese fondue ;)

Needless to say, this entire exercise would be at most a dream were it not for my loving family and in particular to my parents, "Papa et Maman", and my sister, Carole. Our parents always encouraged us to ask questions, to be curious about how things work. Thanks for encouraging us to be independent thinkers, and having confidence in our abilities to go after new things that inspired us. And, of course, thank you both for your constant support through the ups and downs of my academic career. There have been scary times...but your confidence in me has enhanced my ability to get through it all and succeed in the end. Thank you!!

It is not possible to summarize Diane and her influence on me in one paragraph, but I will try. Diane has changed my life over the last years. Her love, honesty and liveliness have given me everything I needed. She has supported me in hundreds of ways throughout this period of our lives. A rapid calculation tells me we've been travelling by train about...200,000 km. just to spend together even the shortest times we had available. Five times going around the globe, just to spend time together means everything to me. I'm sure she understands what I mean, she always does. Oh, and finally, she's said yes! 


\section{Curriculum Vitae}

\section{Personal data}

Name: Franck Muller

Born: 14 January 1997 in Clamart, France

Nationality: French

\section{Education}

Sept. 83 - June 88

Sept. 88 - June 95

Sept. 95 - June 98

Sept. 98 - June 99

Sept. 99 - June 00

Oct. 99 - June 00

Sept. 00 - Jan. 02

Sept. 00 - Jan 02

March 02 - Apr. 06
Primary school in Vanves, France;

Secondary school in Vanves, France with Qualification: « Baccalauréat Général » (Abitur);

DEUG - First level university studies in life sciences (biology and geology) at the University Pierre et Marie Curie (UPMC)Paris VI;

Licence - Second level university studies in biology at UPMC - Paris VI;

Maîtrise - First Msc. Level in biology at UPMC - Paris VI;

Stage at Laboratory for Tropical Biology at UPMC - Paris VI: Studies on the development biology of Beltian bodies in Acacia sp. endemic to Costa Rica and their influence in bitrophic interactions with ant species Pseudomyrmex ferrugineus.

DES - Achievement of Msc degree in life sciences (summa cum laude) at UPMC - Paris VI;

Stage at Laboratory for plant-insect interactions - Institut National de la Recherche Agronomique (INRA), Versailles, France: Research assistant in charge of laboratory and field experiments for the European programme: « Threat to European maize production by invasive quarantine pest, Western Corn Rootworm (Diabrotica virgifera virgifera): a new sustainable crop management approach» including 7 months field work at the INRA Hungary-based research station.

Research Assistant at the CABI Bioscience Switzerland Centre - Arthropod biological control section: in charge of the cabbage seedpod weevil biological control programme. European surveys for candidate parasitoids, assessment of their ecological host range and clarification of their taxonomic status. 


\section{Erklährung}

Hiermiet erkläre ich,

- dass ich diese Arbeit selbständig angefertig habe,

- dass ich wörtlich oder inhaltlich aus anderen Quellen entnommene Stellen als solche kenntlich gemacht habe,

- dass ich die Inanspruchnahme persönlicher Hilfe namenltlich aufgeführt habe,

- dass die Arbeit bisher weder ganz noch zum Teil im Rahmen eines Prüfungsverfahrens vorgelegen hat.

Fûr die mündliche Prüfung wähle ich die Form der Disputation.

Einer Zulassung von Zuhörerinnen und Zuhörern bei der mündlichen Prüfung widerspreche ich nicht. 